\title{
Geological-structural mapping and geocronology of shear zones: A methodological proposal
}

Received: June 2, 2020

Mapeo geológico-estructural y geocronología de zonas de cizalla: Una propuesta metodológica

Anny Julieth Forero Ortega ${ }^{1}$, Julián Andrés López Isaza ${ }^{1}$, Nelson Ricardo López Herrera ${ }^{1}$, Mario Andrés Cuéllar Cárdenas ${ }^{1}$, Lina Mara Cetina Tarazona ${ }^{1}$, Luis Miguel Aguirre Hoyos ${ }^{1}$

1. Group of Tectonics, Dirección de Geociencias Básicas, Servicio Geológico Colombiano, Bogotá, Colombia Corresponding author: Anny Julieth Forero, ajforte056@gmail.com

\section{A B STRACT}

The deformation registered in rocks in the field can be characterized based on the structures preserved in outcrops, which can related be to wide discontinuity zones named faults and shear zones. The geological-structural mapping and the geochronology of these tectonic structures are a topic of great interest not only for tectonic modeling but also for reconstruction of the geological evolution of the national territory. The methodology suggest for the analysis of faults and shear zones is based on eight steps, including: 1) definition of the geological context in which the structure was developed; 2) photointerpretation, image geoprocessing, and geological-structural mapping of the structural and lithological characteristics of the faults and shear zones; 3 ) petrographic analysis of field-oriented samples; 4) quantification of strain orientation and geometry through 3D finite strain analyses and quantification of non-coaxiliaty of deformation through vorticity analyses; 5) SEM-TEM-EBSD microanalysis; 6) quantification of the P-T conditions of deformation through phase-equilibria modeling or conventional geothermobarometry; 7) dating of syn-kinematic minerals phases and mylonitic rocks through Ar-Ar analyses, in order to determine the reactivation and deformation ages of the structure, respectively, as well as the implementation of the U-Pb technique in syn-kinematic calcite crystals developed in the fault planes; and 8) dating of geological elements adjacent to the structure, such as syn-kinematic intrusive bodies associated with the deformation event using zircon $\mathrm{U}-\mathrm{Pb}$ dating, rocks hydrothermally altered through Ar-Ar method, and zircon and apatite fission-tracks dating of the blocks adjacent to the faults for determining exhumation ages.

Keywords: Shear zones, fault rocks, brittle regime, brittle-ductile transition, ductile regime, mapping, geochronology.

\section{RESUMEN}

La deformación registrada en las unidades geológicas en campo se puede caracterizar a partir de las estructuras encontradas en afloramientos, las cuales se relacionan, generalmente, con amplias zonas de discontinuidad denominadas fallas y zonas de cizalla.

Citation: Forero-Ortega, A. J., López-Isaza, J. A., López Herrera, N. R., Cuéllar-Cárdenas, M. A., Cetina Tarazona, L. M., \& Aguirre Hoyos, L. M. (2021). Geologicalstructural mapping and geocronology of shear zones: A methodological proposal. Boletín Geológico, 48(1), 81-122. https://doi.org/10.32685/0120-1425/bol. geol.48.1.2021.524 
El mapeo geológico-estructural y la geocronología de estas estructuras tectónicas es un tema de gran interés, no solo para el modelamiento tectónico, sino para la reconstrucción de la evolución geológica de un territorio. Metodológicamente, para el mapeo geológico-estructural y la geocronología de fallas y zonas de cizalla se sugieren ocho fases, que incluyen: 1) definición del contexto geológico en el cual se desarrolló la estructura; 2) fotointerpretación, geoprocesamiento de imágenes y mapeo geológico-estructural de las características estructurales y litológicas de las fallas y zonas de cizalla;3) análisis petrográfico de muestras orientadas en campo; 4) cuantificación de la orientación y geometría de deformación mediante análisis de deformación finita 3D y cuantificación de deformación no-coaxial por medio de análisis de vorticidad; 5) análisis submicroscópico SEM-TEM-EBSD; 6) cuantificación de condiciones de deformación P-T por medio de modelamiento de equilibrio de fases o geotermobarometría convencional; 7) datación de minerales sincinemáticos y rocas miloníticas por el método Ar-Ar, con el fin de determinar las edades de reactivación y deformación de la estructura, respectivamente, así como, la implementación de la técnica U-Pb en cristales sincinemáticos de calcita desarrollados en los planos de falla y en cristales de apatito con la finalidad de entender la evolución temporal de las zonas de cizalla; y finalmente, 8) fechamiento de elementos geológicos adyacentes a la estructura, tales como: intrusivos sincinemáticos asociados al evento deformacional por el método U-Pb en circón, rocas alteradas hidrotermalmente mediante el método Ar-Ar, y datación por trazas de fisión en circón y apatito de los bloques adyacentes a las fallas para determinar edades de exhumación.

Palabras clave: Zonas de cizalla, rocas de falla, régimen frágil, transición frágil-dúctil, régimen dúctil, mapeo, geocronología.

\section{INTRODUCTION}

The Geological-structural data acquisition for mapping of faults and shear zones is important as basic technical input in the formulation of engineering projects and territorial and national development plans, for the design and layout of road infrastructure with large civil works such as dams, viaducts and tunnels, among others, exploration of water, geothermal, mineral and hydrocarbon resources, for the reconstruction of the deformational evolution of an area, and for studies of regional tectonics (cf. Cox et al., 2001; Sausgruber and Brandner, 2001; Vega Granillo et al., 2009; Mejía et al., 2012; Jiang et al., 2020).

In this regard, it is necessary to develop a unified methodology facilitating fractal qualitative analysis of the pattern of the trace of the shear zone and segments of associated faults (cf. Turcotte, 1989, 1997; Cello, 1997; Park et al., 2010; Barão et al., 2018), from analysis on different scales by photointerpretation, mapping of outcroppings, hand samples and microscopy. This allows establishment of the structural level of the crust represented by the structures, the types of related fault rocks and their distribution, the amplitude over which the movement is distributed, geometry and its respective kinematics, the establishment of structural patterns, and the timing of the deformation.

A shear zone is defined as a high-deformation planar or curviplanar surface, along which the movement is distributed, it presents definite limits characterized by the presence of structures and fault rocks included in centimetric to kilometric areas, according to the scales of deformation (Ramsay, 1980 a, b; Rutter, 1986; Ramsay and Huber, 1987; Jiang and White, 1995; Fossen and Cavalcante, 2017). The shear zones focus the deformation heterogeneously (both coaxial and non-coaxial), arranged as subparallel or conjugate sets (anastomosed) in response to the rheology of rocks and minerals that they affect, and usually are surrounded by lithologies showing low deformation (Ramsay, 1980 a, b; Rutter, 1986; Ramsay and Huber, 1987; Jiang and White, 1995; Fossen and Cavalcante, 2017).

Considering that the deformation is heterogeneously distributed throughout the rock body (Ramsay, 1980 a, b; Ramsay and Huber, 1987; Fossen and Tikoff, 1997; Carreras et al., 2013), it is essential that interpretation of the timing of any deformative event and the analysis of the tectonic evolution of a shear zone is based not only on evaluation of the isotopic dating of the fault rocks (cf. Schneider et al., 2013), but also on the integration of cartography, microstructural analysis, ages of intrusion igneous bodies related to the shear zone, and ages of uplift and exhumation of blocks adjacent to the structure are integrated (cf. Oriolo et al., 2018).

This review presents a methodology for the identification, mapping and analysis of the nature of faults and shear zones. For this, it is suggested to characterize the structures and fault rocks, define the structural level observed, determine the movement's distribution and kinematics, and assign the relative 
and absolute ages of deformation. In order to propose some minimum parameters necessary to perform geological-structural studies for acquiring basic information that aids understanding of the tectonic evolution.

\section{Phases for geological-structural mapping of faults and SHEAR ZONES}

The characterization of geological-structural faults and shear zones, as first to measure, requires correct application of concepts and principles related to the study of faults and shear zones. Furthermore, as a second measure, one should be clear about the objective of the analysis, as well as the "for what?" the structural data are collected, which means being clear about what one will do with the data and how the subsequent analysis will be conducted. Finally, as a third measure, there must be broad and detailed knowledge of the methods of mapping, compilation of structural data, recognition of structures, field classification of fault rocks, collection of structural data with statistical representativeness, and determination of the distribution, kinematics (for which it is necessary to know the kinematic indicators) and geometry.

As a starting point, it is necessary to execute photointerpretation and geoprocessing analysis of satellite images with band compositions that highlight the structures. Such analysis should be complemented by geophysical inputs (e.g., maps of total magnetic intensity, total-field magnetic anomaly, analytical signal of the total-field magnetic anomaly, and complete Bouguer anomaly, among others) and an adequate map base (with drainage networks and contour lines). These allow identification and and definition of the preliminary outline of the structure (cf. Gunn et al., 1997; Betts et al., 2003; Grauch and Hudson, 2007; Aitken and Betts, 2009; Stewart et al., 2009; Stewart and Betts, 2010; Kadima et al., 2011; Blaikie et al., 2014; Armit et al., 2014; Blaikie et al., 2017). This implies the identification of geomorphological features that define the fault or shear zone and sites of interest for subsequent campaigns for field checking.

For mapping structures, it is recommended to perform a multiscale analysis of nature and the spatial distribution of structural elements in the central and marginal areas of the shear zone (Figure 1), in which one will observe the fractal distributions, considering similar arrangements of geological characteristics, independent of the scale of observation (Turcotte, 1989; 1997; Cello, 1997; Park et al., 2010; Fossen, 2013; Baron et al., 2018). This allows identification of the timing of the deformation events basen mainly on cross-cutting relationships. For this, it is suggested to do transects perpendicular to the strike of the structures that limit and constitute the shear zone (cf. Chetty, 2014; Choi et al., 2016), recording morphotectonic, geometric and kinematic characteristics, and acquiring structural data on the fabric developed in the main structure, as well as satellite faults, branches and other secondary structures (e.g., folds, tension gashes and foliations, among others), emphasizing the hierarchical structure of the structures.

Another relevant aspect in the mapping of this type of structure is a description of the associated fault rocks. These are a group of rocks developed in shear zones at different structural levels of the crust, which originate by heterogeneous deformation from cataclistic processes, intracrystalline plasticity or flow, depending on physical conditions of the deformation and the type of affected lithology (Sibson, 1977; 1983; Rutter, 1986; Ramsay and Huber, 1987). These are subdivided into non-cohesive rocks, mainly fault gouge and breccia, and cohesive rocks such as cataclasites and mylonite, which are the result of episodes of intense deformation, which reduce the grain size of the rocks, either by processes of abrasion or intracrystalline plasticity (Sibson, 1977; 1983; Killick, 2003), imprinting particular mechanical characteristics on the rocks (Sibson, 1977; Wise et al., 1984; Spray, 1995; Woodcock and Mort, 2008; Magloughlin, 2010).

The analysis of structural data acquired along fault planes and shear zones starts from the register of the orientation and direction of movement of the fault planes (cf. Petit, 1987; Hancock, 1985; Doblas, 1998). Moreover, it includes the categorization of structural data according to their quality determined in the field (supposed, probable or possible, and true) (Hardcastle, 1989; López-Isaza et al., 2021) and the cross-cutting relationship between the structures and geological units this affects (cf. Angelier, 1994; Sippel et al., 2009; Sperner et al., 1993; Tranos, 2009, 2011; Sperner and Zweigel, 2010). With the fault data, different inversion methods can be used to help determine the principal axes of deformation and stress, from kinematic and dynamic analyses, respectively (cf. Twiss and Unruh, 1998; Žalohar, 2014; Thakur et al., 2020).

The kinematic analysis involves plotting data on different diagrams, like the tangent-lineation (Twiss and Unruh, 1998) or Höeppener (1955), in order to display fault planes as poles, including the relative movement of blocks adjacent to the fault (Sperner and Zweigel, 2010). It is also recommended 
to perform a kinematic compatibility analysis, which allows the establishment of compatible structures kinematically generated or activated under the same deformation event (e.g., Santamaría-Díaz et al., 2008). Furthermore, if possible, one should calculate the principal axes of elongation $\varepsilon 1, \varepsilon 2$ and $\varepsilon 3$ (Sperner and Zweigel, 2010), and it is suggested to use the Linked Bingham method of distribution, which solves the axes of shortening and extension of a set of faults (Marrett and Allmendiger, 1990).

The dynamic analysis is performed based on classification of the subsets established in the kinematic analysis. With each subset, it is recommended to test the mechanical coherence of the data from their distribution on Morh's circle (cf. Velandia, 2017), followed by use of the inversion method of slickensides (Sperner and Ratschabacher 1994), to obtain the paleostress tensors. This method assumes that movement of the fault is controlled by a stress tensor and that the associated failures and slickensides were developed under the same deformation event. Therefore, the direction of the stress field can be determined from the preferential slips of the fault planes (Twiss and Unruh, 1998; Lacombe, 2012). This analysis is based on the following s assumptions: 1) the direction of movement is parallel to the maximum shear stress resolved on the plane (Wallace, 1951; Bott, 1959); 2) the rock behaves as a rheologically linear material (Srivastava et al., 1995); 3) the displacements on the fault planes are independent and small with respect to their lengths, and in them there is no rotation of the planes, obeying the Wallace-Bott criterion; 4) the stress field is homogeneous (Twiss and Unruh, 1998). The inversion method is calculated by graphical (right dihedral method) or mathematical solutions (numerical dynamic analysis), usually included in software of structural data processing (e.g, Wintensor 5.8, TectonicsFP 1.7.7).

On the other hand, considering that the data associated with slip faults may be heterogeneous, it is proposed to apply a genetic algorithm method (MGA, for its acronym in English). This allows direct estimation the states of paleostress from this type of data and does not require the separation of subsets of data (Thakur et al., 2020).

The right dihedral method developed by Angelier and Mecheler (1977) allows one to obtain an optimum orientation of stress fields from the directions and slip sense. It is based on graphing an auxiliary plane perpendicular to the slickensides, which divides the area around each fault plane into four quadrants that define compression and tension zones (Ortner et al.,
2002). From the sum of the areas of solutions for each structural data is obtained the dihedrals resulting from distension and compression corresponding to the dataset, in which the common orientations correspond to the optimal positions of axes $\sigma 3$ and $\sigma 1$ in the dihedrals of extension and compression, respectively (Angelier, 1979, 1994; Sainz et al., 1990; Casas et al., 1990; Delvaux and Sperner, 2003; Delvaux, 2012; Delvaux et al., 2012).

\subsection{Conceptualization and reference geological context}

To do the geological-structural mapping it is necessary to have knowledge of the tectonic and geological context in which the structure developed. Moreover, one should previously consider the concept of shear zones, what characterizes them, their architecture, what their regimes are, and how they relate to depth. This is in order to have a theoretical approach to the depth position in a crustal cross-section or, in other words, the observed structural level of the crust.

On the surface, shear zones are characterized by morphotectonic features (Bull, 2007) that show the landscape forms produced specifically by tectonic processes, rather than by processes of sedimentation and erosion (Keller and Pinter, 2002; McCalpin, 2009; Burbank and Anderson, 2012). These types of features have been extensively documented in neotectonics studies. Among these features can be found mountain fronts with triangular facet, fault escarp, flexural escarp, sag pond, fault saddle, positive (pressure ridge) and negative (pull-apart basin) flower structures, shoulders, shutter ridge, and forebergs, in addition to the development of interference drains, which are very sensitive to changes in the surface, among others.

The identification of morphological and structural features associated with the development of shear zones have been widely characterized by aerial photograph analysis, satellite and radar images, during phases prior to field work, in order to identify the location and distribution of the landscape features, as well as the elevation of the terrain and its composition (Smith and Pain, 2009). These are characteristics that may not be directly recognizable in the field because of their scale.

In this sense, the photointerpretation is a fundamental part of any geological study that involves the recognition of morphological and structural features. Traditionally, aerial photographs have been used, which facilitate a perception of the terrain in $3 \mathrm{D}$ through stereoscopy, with vertical exaggera- 
tion that makes it possible to estimate the slopes, stratification, and terrain configuration. However, given its optical character, its usefulness is restricted by cloudiness and thick vegetation cover, which prevent the assessment of the land (Mendivelso, 2008; Rampal, 1999).

During recent decades, great progress has been made in satellite and remote sensing technologies (Rao, 2002). The variety of available satellite images, with differing spatial, radiometric and temporal resolutions, allows their use in recognizing the composition of the earth's surface, its cover and temporal evolution. One can distinguish two major categories of satellite images: those from passive sensors (e.g., Landsat, Sentinel 1, Aster, SPOT, and others), and those from active sensors, commonly known as radar images (e.g., Sentinel 2, ALOS-PALSAR, GeoSAR, RADARSAT-1, and others). The latter have the advantage of allowing observation of the earth surface even in overcast conditions and at night. Additionally, some of them in the L band go beyond the vegetation cover and penetrate layers of soil, snow or ice (Paine and Kiser, 2003). They are therefore the most useful in geological and geomorphological studies.

Lidar (acronym for light detection and ranging) is another technology of the active type, like radar, which facilitates topographic data of high accuracy and density, so it supports the construction of digital elevation models with high spatial resolution. This technology can be implemented using unmanned aerial vehicles (UAV- drones), which enables the recognition of vast areas. Compared with traditional photogrammetry, Lidar provides data on terrain covered by vegetation (Paine and Kiser, 2003), as shown by the detection and characterization of active faults in wooded areas (e.g., Chen et al., 2015).

To facilitate the detection of fault zones and associated geomorphology features, various algorithms and processing techniques have been created, such as the application of spatial filters that highlight and automatically extract information from satellite imagery (e.g., Gannouni and Gabtni, 2015; Mallast et al., 2011). However, despite the quality and utility of remote sensing tools, field testing is always necessary (Marchionni and Cavayas, 2014) to fully recognize and characterize faults and shear zones.

The architecture, both longitudinal and transverse to the trace of the shear zones, is distributed in three main elements (Caine et al., 1996; Ganerød et al., 2008): core, transition and damage zones (Figure 1). The core corresponds to a zone parallel or semiparallel to the direction of the main fault and is a product of high strain and focused shear, accommodating displacement through one or more surfaces. It is made up of shear zones, sets of conjugate fractures with different orientations, geometry, and morphology (Caine et al., 1991; Caine et al., 1996; Gabrielsen and Braathen, 2014). It also includes lenses or areas of sheared rocks (e.g., foliate cataclasites and mylonites), locally fractured or crushed (e.g., ultracataclasites, breccia and fault gouge), with evidence of processes of precipitation and geochemical alteration (Sibson, 1977; Anderson et al., 1993; Chester and Logan, 1986; Childs et al., 1996; Wibberley et al., 2008; Gabrielsen et al., 2008; Bastesen and Braathen, 2010). Its width can vary from a few centimeters to hundreds of meters (Gabrielsen and Braathen, 2014).

The transitional zone is mainly composed of elongated fragments of protocataclasites and/or protobreccia (Lindanger et al., 2007; Gabrielsen and Braathen, 2014). It also includes fracture corridors, shear and gouge zones of minor faults, arranged in a subangular manner with respect to the general trend of the main fault plane, cross-cutting locally previously formed structures (Gabrielsen and Braathen, 2014). This zone also has of greater cohesion and is generally less affected by processes of hydrothermal alteration, as compared to the fault core (Berg and Skar, 2005; Faulkner et al., 2010; Gabrielsen and Braathen, 2014; Choi et al., 2016).

The damage zone, which surrounds the previous zones, corresponds to the volume of rock that is around the fault core and transitional zone, and preserves the original lithological properties of the deformed rocks (Chester et al., 1993; McGrath and Davinson, 1995; Beach et al., 1999; Storti et al., 2003; Billi et al., 2003; Chester et al., 2004; Berg and Skar, 2005; Johansen and Fossen, 2008; Mitchell and Faulkner, 2009; Gudmundsson et al., 2010; Riley et al., 2010; Hausegger and Kurz, 2013; Lin and Yamashita, 2013; Choi et al., 2016). The damage zone is characterized by thin bodies with rhombuses-shapes, with low deformation intensity (Gabrielsen and Braathen, 2014), as well as by structures of second order, synthetic and antithetic fractures, joints, veins and folds. These are related to the kinematics of the structure, being less representative in relation to increasing distance to the fault core (Chester and Logan, 1986; Smith et al., 1990; Berg and Skar, 2005; Faulkner et al., 2010; Gabrielsen and Braathen, 2014).

Inside the crust, the shear zones present structural levels characterized by the deformation regimes and structures produced in response to the distribution of the deformation, called brittle, brittle-ductile and ductile (Ramsay, 1980 a, b; Rutter, 
1986; Ramsay and Huber, 1987; Fossen and Cavalcante, 2017). In conditions of average geothermal gradient (between $25^{\circ} \mathrm{C}$ and $30^{\circ} \mathrm{C}$ per kilometer), these structural levels are demarcated by limits depending on the rheological characteristics of quartz and the feldspar (Figure 1), which respond to fracturing deformation by abrasive processes (cataclastic) or flowing by accommodation processes (frictional sliding), respectively (Hills, 1972; Sibson, 1979; 1983; Knipe, 1989; Hatcher, 1995; Snoke et al., 1998; Blenkinsop, 2002).

In this regard, the brittle or elastic-frictional regime (Sibson, 1977; 1983; Ramsay, 1980 a, b; Rutter, 1986; Ramsay and Huber, 1987; Hanmer, 1988; Fossen and Cavalcante, 2017) is characterized by fault zones (Sibson, 1979; Chester et al., 1993; Chester and Chester, 1998; Kim et al., 2003; Chester et al., 2004; López et al., 2008; Hausegger and Kurz, 2013; Choi et al., 2016; Ostermeijer et al., 2020) and include interconnected and closely spaced subparallel structures that from fracturing, abrasion, grain-boundaries Sliding, pressure-dissolution and grain size decrease processes favor the development of breccia or gouge fault zones between them (Higgins, 1971; McClay, 1987; Davis and Reynolds, 1996). The fault zones include domains with different deformation intensity, distributed in the fault core and damage zone (Figure 1), characterized by structural elements defined by the variation in fracturing intensity. Furthermore, the development of fault rocks (fault gouge, breccia and cataclasites) and kinematic indicators (major fault -Y, -P shear, riedel shear R, conjugate riedel shear R', tensile fracture - T, crescentic marks, slickenside, congruous and incongruous steps, trailed material, asymmetric protruding grains, carrot-shape, trains of inclined planar structures, asymmetric elevations, mineralogical/crystallographic orientation, among others.) allows definition of the kinematics and type of structure, plus the associated stress field (cf. Hancock, 1985; Petit, 1987; Célérier, 1988; Doblas et al., 1997; Doblas, 1998; Fry, 2001).

Under conditions equivalent to the brittle-ductile regime or elastic-frictional/quasi-plastic transition, in a normal geother-

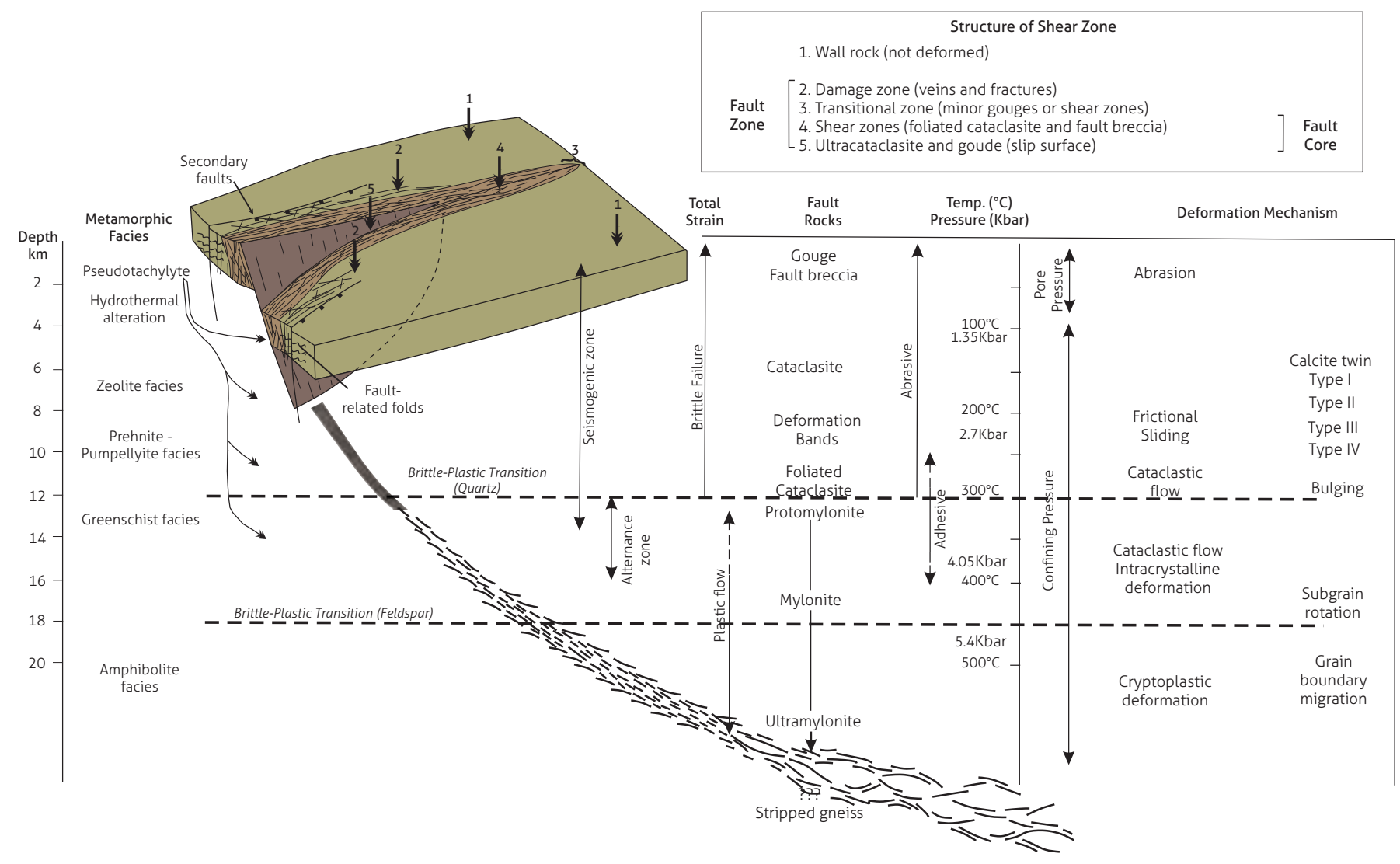

Figure 1. 3D architecture of shear zone, which includes transition from brittle, brittle-ductile and ductile deformation to depth, and their relationship with deformation mechanisms and associated fault rocks

Source: Constructed using information from Sibson (1979; 1983); Wise et al. (1984); Scholz (1988, 2006); Swanson (1992); Passchier and Trouw (2005); Chester et al. (2004); López et al. (2008), Fossen (2013), and Choi et al. (2016). 
mal gradient (Sibson, 1977; 1983; Ramsay, 1980 a, b; Rutter, 1986; Ramsay and Huber, 1987; Hanmer, 1988; Scholz, 1988; Fossen and Cavalcante, 2017), rocks undergo a transition that is registered in the behavior of quartz, which goes from a brittle fracture mode to plastic flow (Rutter, 1986; Duba, 1990). Shear zones developed under this regime show a complex behavior related to processes of granular flow, cataclastic mechanisms and intracrystalline plastic deformations, which result in heterogeneous deformation of the rock with partition in stronger and weaker domains. Under these conditions, the behavior depends on temperature, pressure, rheology, previous anisotropies, and angular and linear geometric relationships in which the structure was generated (Sibson, 1977; Blenkinsop and Rutter, 1986; Scholz, 1988; Schmid and Handy, 1991; Babaie et al., 1991; Hadizadeh and Tullis, 1992; Passchier and Trouw, 2005; Balsamo et al., 2010; Fossen, 2013; Moreira and Dias, 2018; Kjenes, 2018; Nicchio et al., 2018; Barão et al., 2020). Moreover, it includes the development of fault rocks such as cataclasites S-C, phyllonites and protomylonites (Chester et al., 1985; Lin, 1999a; Passchier and Trouw, 2005; Passchier and Coelho, 2006; Trouw et al., 2010; Torgersen and Viola, 2014).

Another term commonly used for this deformation region is semi-brittle shear zones. These are areas of brittle shear influenced by mechanisms of plastic deformation, a situation in which the elements in the structure are intrisically brittle but mechanically resistant to stop the propagation of fractures (Gumbsch, 2001; Fossen, 2013). The fault rocks in semi-brittle shear zones show mineral fragments embedded in a fine matrix of crushed and fractured minerals, veins with mineral precipitation, and evidence of cataclastic flow product of hydrothermal processes, tension gashes, intergranular and transgranular microfractures domino type, and shear bands, the latter contribute to the development of intracrystalline plastic processes (Hodgson, 1989; McClay, 1991; Hadizadeh and Tullis, 1992; Babaie and La Tour, 1993; Gumbsch, 2001; Pec et al., 2012; Prigent et al., 2017; Papeschi et al., 2018; Reber and Pec, 2018; Barão et al., 2020).

In the ductile or quasi-plastic regime (Figure 1) with a normal geothermal gradient (Sibson, 1977; 1983; Ramsay, 1980 a, b; Rutter, 1986; Ramsay and Huber, 1987; Hanmer, 1988; Fossen and Cavalcante, 2017), shear zones are dominated by the mechanical response of feldspar and are generated at deeper levels in the crust, where metamorphic conditions prevail (Sibson, 1983; Riedmüller et al., 2001; Lopez et al., 2008). In these zones, the processes of plastic flow are distributed homo- geneously and involving reduction of grain size. These zones are also characterized by the development of protomylonites, mylonites, ultramylonites, blastomylonites, ribbon mylonites, stripped gneiss, and mylonite gneiss (Sibson, 1980; White et al., 1980; Snoke et al., 1998; Killick, 2003; Passchier and Trouw, 2005; Trouw et al., 2010; Fossen, 2013).

\subsubsection{Fault rocks}

Initially, fault rocks were classified according to the level of primary cohesion and planar fabrics developed (Higgins, 1971; Hills, 1972; Sibson, 1977; Marshak and Mitra, 1988). However, this classification does not consider that under certain conditions cataclastic rocks can present foliation and that the deformation mechanisms that affect fault rocks can be different (cf. Bell and Etheridge, 1973; Ramsay and Huber, 1987; Lin, 1999a).

For the description of fault rocks, it is recommended to consider guidelines of the Subcomission on the Systematics of Metamorphic Rock (SCMR) of the International Union of Geological Sciences - IUGS (Brodie et al., 2007), supplemented by recent reviews that describe the characteristics of fault rocks and classify some of their types (cf. Woodcock and Mort, 2008; Magloughlin, 2010; Fossen and Cavalcante, 2017). The following describes fault rocks according according to the structural level they generate (cf. Figure 1), starting with the brittle regime and ending with the ductile regime. It should be noted that the type of fault rock generated inside the crust also depends on the prevailing geothermal gradient at the time of their formation, which is directly related to depth.

\subsubsection{Fault breccia}

This is a product of the brittle shear zones of the upper crust, and they are developed from the surface to a few kilometers deep in the crust ( 0-6 km; cf. Sibson, 1977) and vary between non-cohesive and cohesive, foliated and non-foliated (Figure 2a) (Higgins, 1971; Sibson, 1977, 1986; Woodcock and Mort, 2008). Based on their cohesion, matrix or cement concentration, and clast size (>2 mm), they are classified as: a) crackle breccia ( $75 \%$ to $100 \%$ of large clasts), with clasts with little rotation, separated by thin cement or matrix sutures; b) mosaic breccia ( $60 \%$ to $75 \%$ of large clasts) with adjacent clasts that fit together, but with more separation and rotation; c) chaotic breccia (30\% to $60 \%$ of large clasts), with strongly rotated clasts and loss of geometric fit to each other (Woodcock and Mort, 2008; Magloughlin, 2010). 


\subsubsection{Fault gouge}

This is a non-cohesive rock with less than $30 \%$ large clasts (> $2 \mathrm{~mm})$, formed in the first kilometers of the upper crust $(\sim 0-4$ $\mathrm{km}$; cf. Sibson, 1977) from cataclassic processes dominated by fracturing and rotation of the rigid body of grains and fragments. It is restricted to shear fractures and slip planes in fault zones (Figure $2 \mathrm{~b}$ ) and it is composed by a material rich in clay, which can present foliation and plastic response in the presence of moisture (Higgins, 1971; Engelder, 1974; Wu, 1978; Chester et al., 1985; Scholz, 1987; 1988; Snoke et al., 1998; Killick, 2003; Vannucchi et al., 2003; Woodcock and Mort, 2008; Magloughlin, 2010; Haines et al., 2013; Vrolijk et al., 2018).

\subsubsection{Cataclasite}

This denomination classifies a cohesive rock with or without foliation (figure 2c), developed in the upper crust at depths shallower than those of the ductile-brittle transition ( $\sim 4-10$ $\mathrm{km}$ ) (Figure 1). It is characterized by angular porphyroclasts in a fine-grained matrix of similar composition, which are deformed by mechanisms associated with processes of cataclastic and granular flow, fracturing, rotation and frictional sliding of particles (Higgins, 1971; Sibson, 1977; 1979; Scholz, 1988; Blenkinsop and Rutter, 1986; Babaie et al., 1991; Hadizadeh and Tullis, 1992; Snoke et al., 1998; Woodcock and Mort, 2008; Magloughlin, 2010; Balsamo et al., 2010; Moreira and Dias, 2018; Kjenes, 2018; Nicchio et al., 2018; Barão et al., 2020). According to the degree of proportion of the matrix (cf. Sibson, 1977; 1979; Snoke et al., 1998; Woodcock and Mort, 2008; Magloughlin, 2010), it is classified as: a) protoclasite, in the which the matrix makes up less than $50 \%$ of the rock volume; b) mesocataclasite, for which the matrix comprises more than $50 \%$ and less than $90 \%$ of the rock volume; c) ultracataclasite, in which the rock volume consists of more than $90 \%$ matrix and is restricted to fault cores where the shear concentrates (Figure 1); d) S-C cataclasites, which are characterized by a shape orientation of some mineral phases (S planes) and the generation of micro-shear planes or shear bands (C planes), with quartz and feldspar crystals developing brittle deformative microstructures with no dynamically recrystallized grains in conditions of temperatures between $150^{\circ} \mathrm{C}$ and $250^{\circ} \mathrm{C}$ (Chester et al., 1985; Lin, 1999a).

\subsubsection{Phyllonite}

Cohesive rock with phyllitic appearance, formed by processes of aseismic creep (drag) (Higgins, 1971; Sibson, 1977; Pass- chier and Trouw, 2005; Trouw et al., 2010; Torgersen and Viola, 2014) or by syndeformational fluid circulation and flow during its generation (cf. Spruzeniece and Piazolo, 2015). It may be related to cataclasites and mylonites and develops transitional contacts with protomylonite in some shear zones, locally with complete lateral variation of the structure, or hosting quartz tension cracks (cf. Hippertt and Massucatto, 1998).

\subsubsection{Mylonite}

This designation includes cohesive rocks with mineral-stretching lineations (Figure 2d), strongly deformed in a ductile shear zone, surrounded by less deformed rocks, developed at depths equivalent to the middle-lower crust (Figure 1), under a normal geothermal gradient. It is characterized by two types of well-defined foliation, called S-C structures (Figure 2e), which result from a reduction in grain size from plastic processes. They are also constituted by lithic fragments or porphyrioclasts of type $\sigma, \delta$, fish or sigmoidal, in addition to porphyroclastic systems with the development of mantle-core structures, quarter structures, reaction rings, and deformation shadows that, generally, have a composition similar to that of a fine-grained matrix (Bell and Etheridge, 1973; Lister and Snoke, 1984; Hooper and Hatcher, 1988; Hanmer, 1989; Ten Grotenhuis et al., 2003; Passchier and Trouw, 2005; Brodie et al., 2007; Trouw et al., 2010; Barão et al., 2020). Classification is based on the proportion of its original grains (size) and the recrystallized matrix (Sibson, 1977, 1979; Scholz, 1988; Snoke et al., 1998; Brodie et al., 2007; Woodcock and Mort, 2008; Magloughlin, 2010; Fossen and Cavalcante, 2017), and includes: a) protomylonite, in which less than $50 \%$ of the rock has been subjected to grain-size reduction processes and has greater development on C planes; b) (meso)mylonite, in which more than $50 \%$ and less than $90 \%$ of the rock shows grain-size reduction processes; c) ultramylonite (Figure $2 \mathrm{f}$ ), in which more than $90 \%$ of the rock shows grain-size reduction; d) blastomylonite, corresponding to rocks that once deformation has ceased, increase the grain size due to processes associated with static recrystallization. However, this term is sometimes used to describe mylonites with a coarse-grained recrystallized matrix (Passchier and Trouw, 2005).

Besides the above descriptions of mylonites, other terms are also used, such as augen mylonite, used to describe rocks generated from a combination of cataclastic and crystalloblastic processes that show crystals or lithic fragments, generally of lenticular shape (larger than $0.5 \mathrm{~mm}$ ), embedded in a 

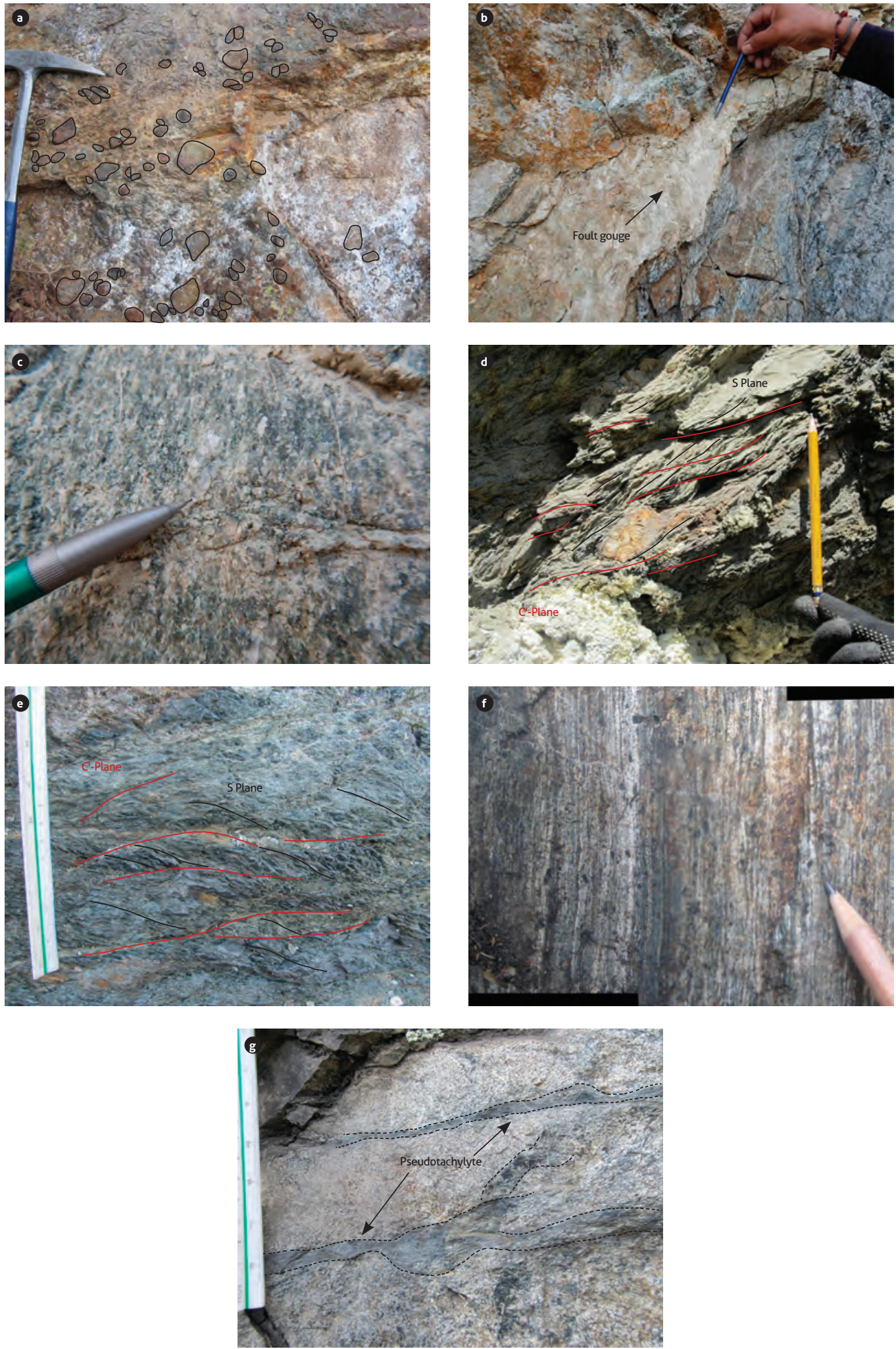

Figure 2. General appearance of a fault rock outcrop

a) Cohesive and non-foliated fault breccia; b) fault plane with fault gouge; c) foliated cataclasite; d) Mylonite with mineral orientation defined by the presence of milky quartz porphyroclasts; e) S-C structure characteristic of mylonites; f) ultramylonite with porphyroclasts of mafic minerals and oxides; $g$ ) pseudotachylite injection veins. 
fine-grained matrix (recrystallized or neoformed), which shows deformation in solid state (Passchier and Trouw, 2005; Mukherjee, 2014). These rocks generally form symmetric or asymmetric anastomosed planar structures, consisting mainly of felsic minerals (Higgins, 1971; Brodie et al., 2007). The term ribbon mylonite is also used to describe strongly foliated rocks, mainly constituted by parallel monomineralic lenses (Passchier and Trouw, 2005; Trouw et al., 2010), common in high-grade shear zones that are transitional deformed to stripped gneisses. The stripped gneisses correspond to rocks interpreted as mylonites with gneissic structure defined by planar compositional, formed under high-grade metamorphism (Hippertt, Rocha et al., 2001; Passchier and Trouw, 2005; Trouw et al., 2010).

\subsubsection{Pseudotachylites}

These originate from (paleo)seismic movements producing melting during rapid frictional sliding and are mainly characterized by evidence of a a precursor melt phase (Magloughlin, 2010; Kirkpatrick and Rowe, 2013). The pseudotachylites occur as phases included within veinlets and veins with thicknesses from millimetric to centimetric (Figure $2 \mathrm{~g}$ ). They may consist of glass, devitrified glass, oxides, carbonates, chlorite and even epidote, as veins of the main fault plane, generation veins or injection veins, with sharp contacts, locally corroded, and cooling margins (cf. Lin, 2008; López et al., 2008; Magloughlin, 2010; Kirkpatrick and Rowe, 2013; Altenberger and López, 2014). They are constituted by fragments of broken crystals from host rock embedded in a matrix ranging from

Table 1. Recommended synoptic table for the textural classification of fault rocks

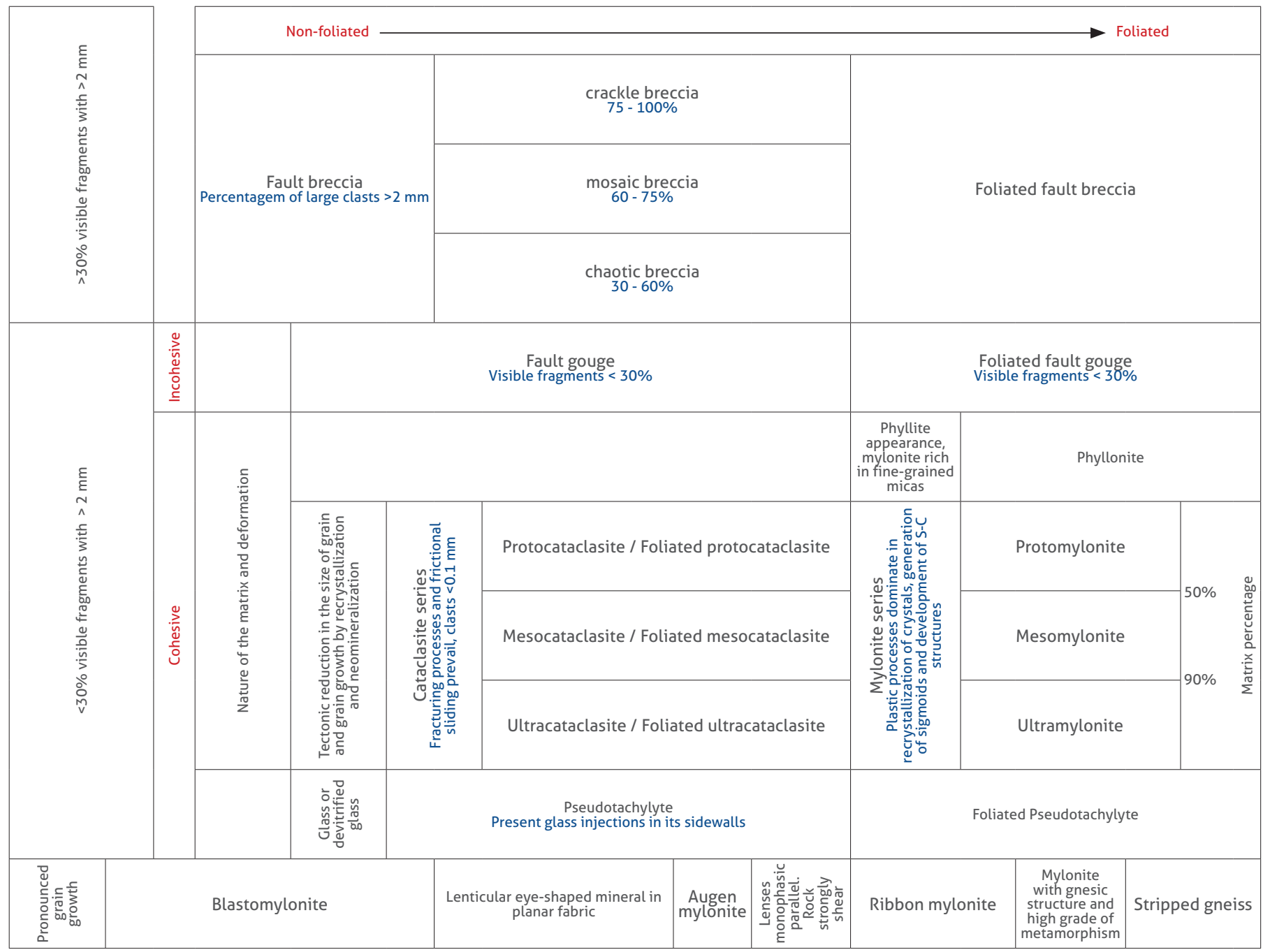

Source: Prepared with information from Sibson (1977; 1979); Scholz (1988), Snoke et al. (1998), Killick (2003), Woodcock and Mort (2008), and Magloughlin (2010). 
cryptocrystalline to aphanitic, which develop structures due to flow, compositional banding, and spherulites caused by rapid cooling and devitrification (Philpotts, 1964; Sibson, 1975; Snoke et al., 1998; Lin, 1999b; 2008; Wenk et al., 2000; Winter, 2001; Passchier and Trouw, 2005; López et al., 2008; Magloughlin, 2010; Fossen, 2013; Kirkpatrick and Rowe, 2013; Altenberger and López, 2014).

\subsubsection{Classification of fault rocks in the field}

For fault rock classification in the field, it is suggested to use a tabular summary (Table 1 ) that synthesizes the previously described features, which includes the minimum classification parameters based on descriptions of the lithologic, physical, mineralogical, structural and textural characteristics of the rocks to be classified.

\subsection{Petrography and microtectonics}

Before performing the petrographic and microtectonic analyses, it is suggested to have control over the orientation of the sample collected in the field (Figure 3), indicating in the sample basic information related to the attitude of the plane, which should be orientated by specifying the strike of the reference surface according to the right-hand rule. It is also necessary to mark geographic North, the base (lower plane) and the top (upper plane), and the free faces of the sample (cf. Turner and Weiss, 1963; McClay, 1987; Passchier et al., 1990; Hopgood, 1999; Passchier and Trouw, 2005).

In the preparation of thin sections, one should consider that the tectonically deformed rocks can develop planar and linear fabrics, which are associated geometrically with the deformation ellipsoid, in which the greater mineral linetion is

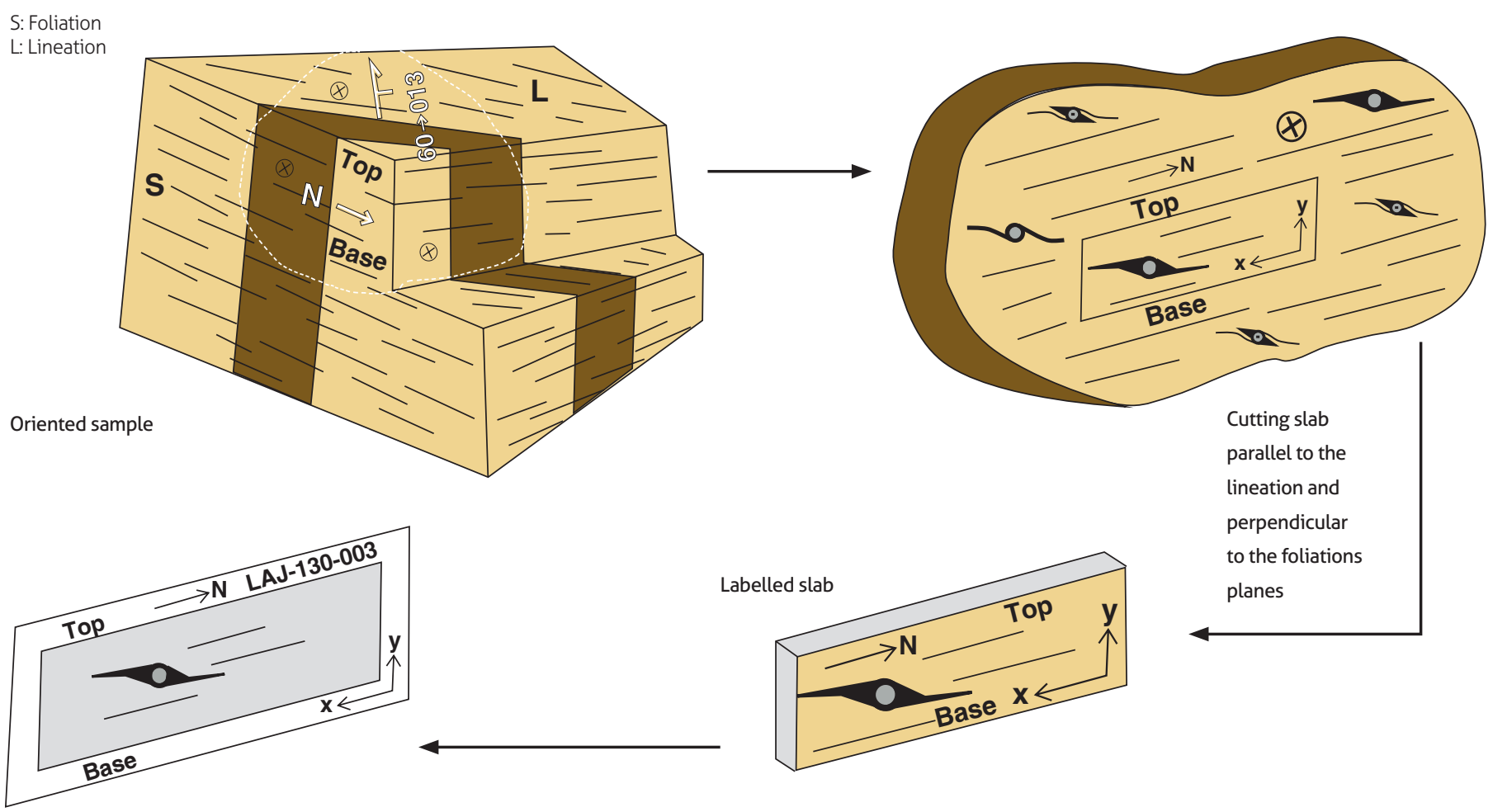

Thin section with the information recorded

during its sampling

Figure 3. Schematic illustrating the orientation of the sample in the field

The direction of geographic North $(\rightarrow \mathrm{N})$, structural data, free face, and top and base are indicated. The cut oriented to obtain the labelled slab must be parallel to the mineral linetation and perpendicular to the foliation. Finally, on the thin section for petrographic and microtectonic analysis, the information recorded in the field is indicated as a reference for interpretation of the kinematics in relation to the sample orientation. Source: Prepared with information from Passchier and Trouw (2005), and García (2011). 
generated along the $\mathrm{X}$ direction and the foliation correspond to the XY planes of the ellipsoid (Flinn, 1979; Ramsay and Huber, 1983; Passchier and Trouw, 2005; Fossen, 2013). To make a cut that reveals the greatest deformation, and additionally, the geometry and direction of movement registered by the kinematic indicators is observed, a section normal to the axis of deformation symmetry must be defined (XZ section of the deformation ellipsoid). This corresponds to the direction perpendicular to the foliation and parallel to the mineral lineation or direction of stretching of the linear fabric elements of interest (Figure 3) (Lister and Hobbs, 1980; Schmid and Casey, 1986; Law, 1990; Hippertt, Lana et al., 2001; Passchier and Trouw, 2005; Trouw et al., 2010; Rutter et al., 2011; Parsons et al., 2016; Goswami et al., 2018). A thin section normal to the mineral direction and parallel to the planes of foliation do not reflect the geometry of the kinematic indicators, because in this cut will be observed $\Phi$ and $\theta$-type porphyroclasts and porphyroblasts. These do not exhibit deformation shadows, and thereforethey do not allow the establishment of a kinematic sense (Passchier and Trouw, 2005; Trouw et al., 2010; Davis et al., 2011). It is important also that the thin section replicates the information registered for the rock during sampling, i.e., which show the coordinate axes, geographic north and indications of top and base, among other aspects.

According to the mechanical response of the minerals, the conditions of pressure, temperature, differential stresses and deformation rate under the deformation occurs it is possible microscopically observe the following deformation mechanisms (Blenkinsop, 2002; Passchier and Trouw, 2005).

1. Brittle fracturing - a cataclastic flow, in which fragmentation, rotation and frictional sliding occurs between grain boundaries through inter and intragranular or transgranular microfractures, whether those microfractures are between the grains, affect one grain, or pass through several grains, respectively (Passchier and Trouw, 2005). This mechanism occurs mainly in brittle conditions of low temperature $\left(\sim 150\right.$ through $\sim 400{ }^{\circ} \mathrm{C}$ ) (Blenkinsop and Rutter, 1986; Hadizadeh and Tullis, 1992; Picazo et al., 2013; Baron et al., 2020) and high deformation rates.

2. Intragranular deformation, assisted by dissolution-precipitation processes, responsible for accommodating deformation along the contact surface between the grains or minerals, under semi-brittle regime and brittle-ductile transition conditions.
3. Intracrystalline deformation, which orders point defects and linear distortions along the lattice planes of the crystal, in conditions of brittle-ductile transition, developing deformation lamellae, twinning, undulatory extinction, and microkinks.

4. Processes of recovery and recrystallization, mechanism generating displacement and organization of dislocations, to be accumulated in the form of planes subsequently generate subgrain limits along the edges of larger crystals. One can identify three deformation mechanisms in dynamic recrystallization: bulging (BLG) (Figure $4 \mathrm{a}$ ), subgrain rotation $(S G R)$ (Figure $4 \mathrm{~b}$ ) and grain boundary migration (GBM) (Figure $4 \mathrm{c}$ ), developed in ranges of deformation temperatures $\sim 300-410{ }^{\circ} \mathrm{C}, 410-520{ }^{\circ} \mathrm{C}$ and $>520{ }^{\circ} \mathrm{C}$, respectively (Zulauf, 2001; Stipp et al. 2002; Faleiros et al., 2010). At low temperatures $\left(<400^{\circ} \mathrm{C}\right)$, the calcite is deformed by crystalloplastic processes along the twinning planes, called "e planes" (Despaigne and Caceres, 2009). According to the geometry in which the twinning planes develop, it is possible to estimate the deformation temperature conditions of the calcite crystals. These are classified as: a) type I, developed at temperatures of $170{ }^{\circ} \mathrm{C}$ (Burkhard, 1993; Passhier and Trouw, 2005; Despaigne and Caceres, 2009); b) type II, which occur at $150-300{ }^{\circ} \mathrm{C}$ (Ferrill, 1991; Ferrill et al., 2004; Despaigne and Caceres, 2009); c) type III, which develop at temperatures $>200{ }^{\circ} \mathrm{C}$ (Burkhard, 1993; Despaigne and Caceres, 2009), d) type IV, developed at temperatures $>250$ ${ }^{\circ} \mathrm{C}$ (Burkhard, 1993; Ferrill et al., 2004; Despaigne and Cáceres, 2009).

5. Solid-state diffusion creep, which occurs mainly at high temperatures, and is related to the transfer of atoms along grain boundaries. It generates curved contacts and chemical zonations.

\subsection{D finite deformation and kinematic vorticity analysis}

The $3 \mathrm{D}$ finite deformation analysis is based on the calculation of the deformation ellipsoid, which characterizes the planar and linear fabrics of the deformed rocks (corresponding to the $\mathrm{XY}$ planes and $\mathrm{X}$ axis of the finite deformation ellipsoid, respectively) (Passchier and Trouw, 2005) and quantifies its scalar parameters of magnitude and shape ( $T$ parameter, Jelinek, 1981; Flinn parameter or K value, Ramsay and Huber, 1983; degree of anisotropy, Ramsay and Huber, 1983; Borradaile and Werner, 1994; Lagroix and Borradaile, 2000; Nakamura 

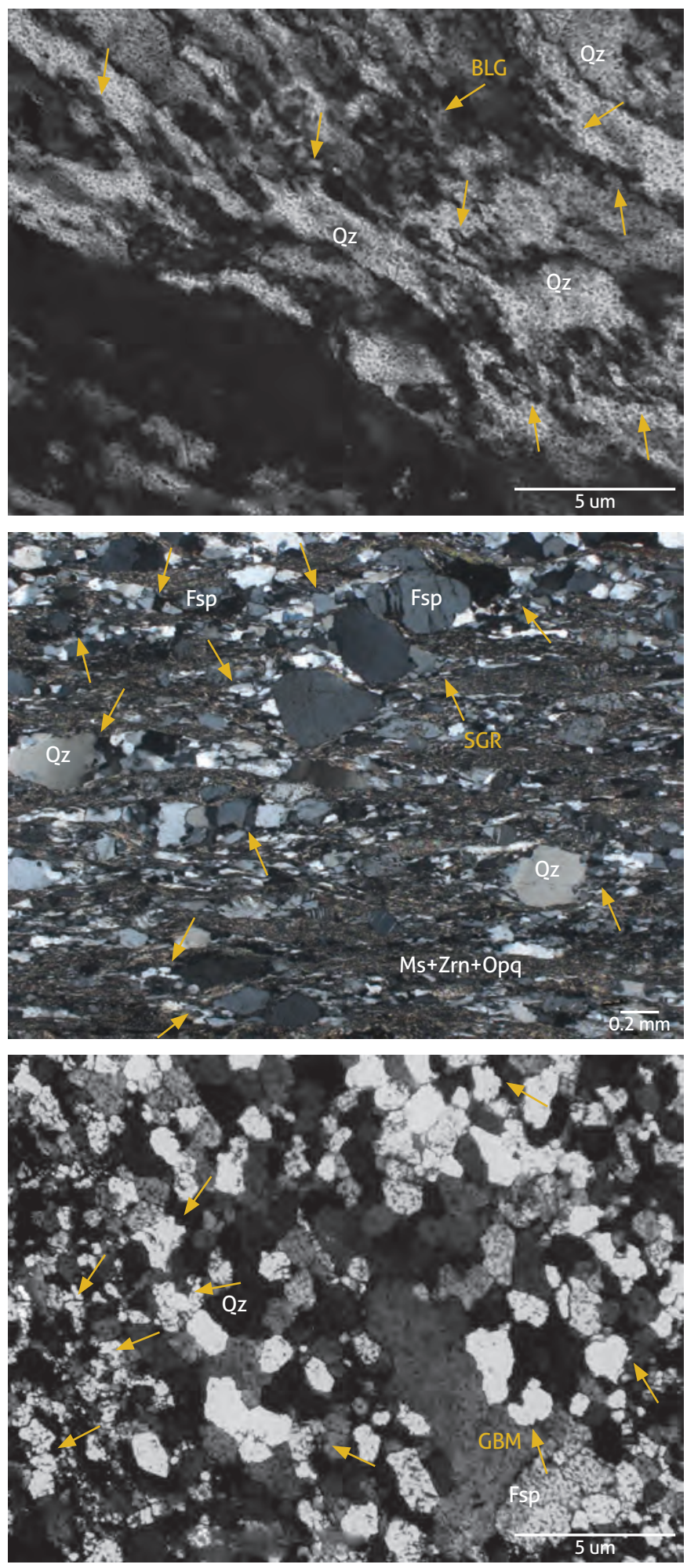

Figure 4. Microphotographs of samples showing intercrystalline plasticity processes evidenced by deformation mechanisms

a) Bulging; b) Subgrain rotation; c) Grain boundary migration. Yellow arrows indicate sites where one observes the dynamic recrystallization previously described (see text) and Borradaile, 2004). This analysis usually implements the inertial tensor (cf. Launeau and Cruden, 1998) and quadratic tensor (cf. Robin, 2002; Launeau and Robin, 2005) methods. It assumes that the deformation was homogeneous and that the crystals initially had equidimensional shapes. Therefore, the quantification of the geometric properties of the deformation ellipsoid and orientations of its main axes reflect the planar and linear structures developed in the rock body (Launeau and Robin, 2005; Passchier and Trouw, 2005). From the shape geometry and the orientation of the ellipsoid obtained, it is also possible to determine the nature of the deformation (coaxial vs. non-coaxial shear, and constructional vs. flattening deformation) and the stress regime under which the shear zone developed (transtension, transpression, shearing, tension and compression) (cf. Sanderson and Marchini, 1984; Fossen and Cavalcante, 2017; Riberio et al., 2019; Forero-Ortega et al., 2020).

The vorticity analysis determines and quantifies the kinematics of the flow in the shear zones (Xypolias, 2010). It focuses on the interpretation of structural fabrics in terms of the degree of noncoaxiality, i.e., evaluating the relationship between rotation and flow stretching components via numerical modeling (cf. McKenzie, 1979; Means et al., 1980; Lister and Williams, 1983), which quantifies the values of kinematic vorticity $\left(\mathrm{W}_{\mathrm{k}}\right)$ (Truesdell, 1953), sectional kinematic vorticity $\left(\mathrm{W}_{\mathrm{n}}\right)$ (Passchier, 1997), and mean kinematic vorticity $\left(\mathrm{W}_{\mathrm{m}}\right)$. This analysis implements $2 \mathrm{D}$ methods on surfaces parallel to the $\mathrm{XZ}$ plane of the finite deformation ellipsoid, in order to estimate the spatial contribution of the simple and pure shear components in deformation zones in terms of $\mathrm{W}_{\mathrm{m}}$ or $\mathrm{W}_{\mathrm{n}}$ values, such as the distribution of linear materials (dikes or sets of deformed veins) (cf. Wallis, 1992; Kumerics et al., 2005; Short and Johnson, 2006), rotation of rigid objects (cf. Johnson et al., 2009; Langille et al., 2010, Thigpen et al., 2010; Forero-Ortega et al., 2020), inclusion patterns in porphyroblasts (cf. Beam and Fisher, 1999; Iacopini et al., 2007), $\mathrm{R}_{\mathrm{xz}} / \beta$ method (cf. Sarkarinejad et al., 2010; Law, 2010; Xypolias et al., 2010), $\delta / \beta$ method (cf. Xypolias, 2009; Ribeiro et al., 2019) and others (cf. Xypolias, 2010).

\subsection{Submicroscopic SEM-TEM-EBSD analysis}

The Scanning electron microscopy (SEM) and transmission electron microscopy (TEM) analyses with electron backs-cattering diffraction (EBSD) are performed to evaluate textures and compositions (number of phases), based on quantitative 
microstructural analysis of crystallographic disorientation angles (characteristics of the boundary mineral) and the average shape and size distribution. These analyses also characterize crystallographic textures, intracrystalline deformation, dynamic recrystallization mechanism, and preferential crystallographic orientation (cf. Behrmann and Mainprice, 1987; Prior et al., 1999; Maitland and Sitzman, 2007; Mariani et al., 2008. Chen and Thomson, 2010; Kilian et al., 2011; Oliot et al., 2014; Platt, 2015; Desbois et al., 2016; Vrolijk et al., 2018; Cavalcante et al., 2018; Goswami et al., 2018; Scheiber et al., 2019; Bella et al., 2019; Ribeiro et al., 2019; Ault, 2020; Conte et al., 2020).

These analyses are carried out on fine-grained minerals in mylonites (mainly quartz and feldspar crystals), which define the transitions of structural levels and rheological conditions of the crust, as well as the location of deformation and development of the shear zone, depending on the prevailing geothermal gradient. These analyses are also performed on clay minerals in fault gouge and iron oxide precipitates developed along the sliding planes, for which it is not possible to easily observe the deformation mechanisms generated, the geometry, and the direction of movement registered by the kinematic indicators.

\subsection{Geothermobarometry and thermodynamic modeling}

Geothermobarometry has wide applications in the study of pressure and temperature conditions of the various phases and associations of mineral phases. These include establishing the emplacement depth of plutonic bodies (cf. Hammarstrom and Zen, 1986; Bohlen and Lindsley, 1987; Schmidt, 1992; Moazzen and Drop, 2005; Bernet et al., 2019; Cetina et al., 2020), determination of the metamorphic peak of metamorphic rocks, and definition of pressure-temperature-time path (cf. Bohlen and Lindsley, 1987; Essene, 1989; Spear, 1993). The objective of geothermobarometry is to infer the pressure and temperature conditions under which a sample has reached equilibrium (cf. Spear, 1993). The description of geothermometers and geobarometers, as well as the analytical methods used, is beyond the scope of this review, therefore, the interested reader can consult Essene (1989), Spear (1993), and Powell and Holland (1994, 2008) for the basis, and Moecher and Brearley (2004), Grujic et al. (2011), Cross et al. (2015) and Cao et al. (2017), among others, for specific applications to fault rocks.

Starting from petrographic and microtectonic analyses, the aspects that must be considered when conducting geothermobarometry studies in fault rocks involve: 1) recognition of the main deformation structures and kinematic indicators; 2) determination of the paragenesis and equilibrium mineral assemblage present in the rock related to the structures and kinematic indicators; 3 ) definition of minerals susceptible to microanalysis, in order to obtain compositional data for geothermometry (e.g., chlorite, quartz and mullite) and geobarometry (e.g., white mica or fengite, plagioclase + garnet); 4) calculation of pressures and temperatures.

It has been considered that the deformation in shear zones may affect the rates and mechanisms of chemical equilibrium in different mineral phases (cf. Steffen and Selverstone, 2006; Richard et al., 2014). The combination of metamorphism and deformation causes transient changes in the speed of the reactions and kinetic pathways that generate mineral associations in chemical equilibrium. These processes, therefore, affect the accuracy and uncertainty of results obtained from geothermobarometers analysis, thus evidencing the presence of heterogeneities or chemical imbalances (cf. Steffen and Selverstone, 2006).

To minimize uncertainties caused by chemical imbalances, another method used to obtain pressures and temperatures is thermodynamic modeling. This method allows the prediction of mineral phases in equilibrium within certain pressure and temperature ranges, based on a given chemical composition, and aims to understand the evolution of mineral associations (Spear, 1993). The diagrams that include mineral associations distributed in stability fields are called pseudosections, and correspond to maps or sections of phase diagrams that show the mineral equilibrium that can be used to predict the pressure-temperature conditions in which the major mineral associations are generated (Tinkham, 2007; Vernon and Clarke, 2008), from specific compositions of total rock (Powell et al., 1998; Zuluaga et al., 2006; Tinkham, 2007).

Starting from petrographic analysis, the aspects that must be considered to do thermodynamic modeling of fault rocks include: 1) defining the mineral phases to be modeled; 2) establishing the chemical components of the system; 3 ) determining the chemical system that defines the phase equilibrium (e.g., $\mathrm{KFMASH}$, which corresponds to $\mathrm{K}_{2} \mathrm{O}, \mathrm{FeO}, \mathrm{MgO}, \mathrm{Al}_{2} \mathrm{O}$, $\mathrm{SiO}_{2}, \mathrm{H}_{2} \mathrm{O}$ ); 4) finding the intensive variables or degrees of freedom of the system to be modeled by application of the phase rule; 5) running the Gibbs free energy minimization routine (e.g., Perple_X); 6) constructing the P-T (pressure-temperature) pseudosection. Additionally, if geothermobarometry data are available, the P-T trajectories can be reconstructed. 
Construction of a pseudosection is done using software, among which Thermocalc (Powell and Holland, 2001 and 2005; Zuluaga et al., 2006; Tinkham, 2007; https://hpxeosandthermocalc.org), Theriak Domino (De Capitani and Petrakakis, 2010; https://titan.minpet.unibas.ch/minpet/theriak/ theruser.html), and Perple_X (Connolly, 2005; 2009; http:// www.perplex.ethz.ch) stand out. The software description is beyond the scope of this review, so the reader is referred to the links cited above. Pseudosections are used in the modeling of faulting controlled by fluid infiltration in mylonites at different structural levels (cf. Selverstone et al., 2012; Précigout et al., 2017), of seismically coupled and uncoupled segments in subduction interfaces (cf. Angiboust et al., 2015) and the metamorphic rocks that host the shear zones (cf. Forero-Ortega et al., 2020). The pseudosections also demarcate deformation histories evidenced in most cases by prograde and retrograde segments of P-T paths owing to shear (cf. Steffen and Selverstone, 2006).

\section{Estimation OF THE DEFORMATION AGE OF FAULTS AND SHEAR ZONES}

Fault and shear zones control the distribution of deformation throughout the lithosphere and play a fundamental role in the emplacement of magmas and circulation of fluids (Ramsay, 1980b; Sibson, 1990; Brown and Solar, 1998; Micklethwaite et al., 2010; Vauchez et al., 2012; Clerc et al., 2015; Smeraglia et al., 2016; Précigout et al., 2017). Therefore, understanding of the timing of activity in the fault and shear zone is essential to comprehend the tectonic evolution in a specific geological context. For this, it is necessary to integrate the mapping and analysis of structures at macro and micro-scales, geochronological and thermochronological data that help determine directly and indirectly the thermal history of a shear zone over time, related to processes of exhumation, uplift and sedimentation associated with evolution of the structure (Bossi and Cam- pal, 1992; Oyhantçabal et al., 1993; Oyhantçabal et al., 2001; Zwingmann and Mancktelow, 2004; van der Plujim et al., 2006; Löbens et al., 2011; Davids et al., 2013; Hnat and van der Pluijm, 2014; Viola et al., 2016; Oriolo et al., 2016 a, b; Ring et al., 2017; Süssenberger et al., 2017).

\subsection{Geochronology of fault rocks}

In order to delimit the deformation age in shear zones, determined in a relative way from field observations such as cross-cutting relationships between the structures and the geological units, generation of zones or surfaces erosion and discontinuities, among others, the use of geochronological and thermochronological methods is recommended for fault rocks or lithological units that constitute blocks adjacent to the shear zones (Table 2). The most relevant isotopic systems and dating methods for the study of shear zones are highlighted in certain reviews (cf. Ohtani et al., 2004; Oriolo et al., 2018; Hueck et al., 2020; and references cited therein). In brittle deformation conditions, methods such as K-Ar and Ar-Ar in neoformed phyllosilicates, such as chlorite, white mica, sericite, muscovite and illite have been implemented (cf. Crone, 1996; Chan et al., 2000; Jefferies et al., 2006; McWilliams et al., 2007; Vinasco, 2001; Löbens et al., 2011; Oyhantçabal et al., 2012; Wang et al., 2016), in fault gouge (cf. Vrolijk and van der Plujim, 1999; van der Pluijm et al., 2001; Zwingmann and Mancktelow, 2004; Haines and van der Plujim, 2008; Duvall et al., 2011; Fitz-Díaz and van der Plujim, 2013; Viola et al., 2016; Scheiber et al., 2019) and in the pseudotachylite matrix (cf. Crone and Omdahl, 1987; Sherlock and Hetzel, 2001; Magloughlin et al., 2001; Streepey et al., 2002; Cosca et al., 2005; Reiners and Brandon, 2006; Whitmeyer, 2008; Cassata et al., 2009; Sherlock et al., 2009; Wolff et al., 2012; Di Vincenzo et al., 2013; Bense et al., 2014; Viola et al., 2016; Süssenberger et al., 2017, Vrolijk et al., 2018). Likewise, U-Pb and U-Th analyses in veins and fibres of calcite and opal precipitated on the fault planes have been performed (cf. Verhaert et al., 2003; Uysal et al., 2007;

Table 2. Synthesis of materials and methods proposed to establish the age under different thermal conditions present in the shear zones, and the probable interpretation of these data

\begin{tabular}{|c|c|c|c|}
\hline Deformation conditions & Material for dating & Proposed dating methods & Probable interpretation \\
\hline Brittle & Quartz grains that constitute the fault gouge & Electron spin resonance (ESR) & Reactivation age of fault zone \\
\hline Brittle & Hematite, magnetite and goethite precipitate & (U-Th)/He and fission track & Reactivation age of fault zone \\
\hline Brittle & Veins and fibers of calcite in fault planes & $\mathrm{U}-\mathrm{Pb}$ & $\begin{array}{l}\text { Reactivation age of fault zone or syntectonic } \\
\text { precipitation }\end{array}$ \\
\hline Brittle & Neoformed micas & $\mathrm{Ar}-\mathrm{Ar} / \mathrm{K}-\mathrm{Ar}$ & Reactivation age of fault zone \\
\hline Brittle/Brittle-ductile & Neoformed micas, fault gouge, and pseudotaquilite matrix & $\mathrm{Ar}-\mathrm{Ar} / \mathrm{K}-\mathrm{Ar}$ & Reactivation age of fault zone \\
\hline Ductile & Neoformed micas in mylonites & $\operatorname{Ar}-\mathrm{Ar}$ & $\begin{array}{c}\text { Reactivation age, cooling or isotopic resetting of shear } \\
\text { zone }\end{array}$ \\
\hline Ductile & Pre and synkinematic minerals in mylonites & $\mathrm{U}-\mathrm{Th}-\mathrm{Pb}$ & Deformation age in shear zone \\
\hline
\end{tabular}


Watanabe et al., 2008; Nuriel et al., 2011, 2017, 2019; Roberts and Walker, 2016; Pagel et al., 2018), in order to establish the age of reactivation of the shear zones (Kelley, 2002).

The U-Pb geochronology in calcite is proposed because calcite can register a rapid deformation event at low temperature in the upper crust, process that would be difficult to dated radiometrically with other minerals, since they do not have the time necessary to crystallize and record deformation under these conditions. Therefore, calcite constitutes an effective chronometer that relates deformation processes (development of faults and folds) and hydrothermal mineralization (cf. Roberts and Walker, 2016; Goodfellow et al., 2017; Mottram et al., 2018, Beaudoin et al., 2018; Roberts et al., 2020a). The main objective is the $\mathrm{U}-\mathrm{Pb}$ dating of calcite crystals in mineralized fault planes that show textures filled by fracturing and sealing (crack-seal) (Nuriel et al., 2011; Robert and Walker, 2016). Likewise, the material to be dated must be present in syntectonic structures upon the brittle deformational event, either as tension gashes or fault-gouge injection veins, and displaying some of the following characteristics (Nuriel et al., 2011; Dressel et al., 2018; Miranda et al., 2020; Roberts et al., 2020b): 1) crack seal textures with sliding in micro pull-apart structures; 2) crack seal textures with growth fiber lineation; 3) crack seal textures within implosion breccia structures; 4) sigmoidal, in echelon, and pocket-type shapes with normal kinematics, the latter associated with discontinuous veins, massive internal textures, brechoid or sheared.

To guarantee the simultaneity of the calcite and deformational event that gave rise to its precipitation, i.e., the temporal relationship between the fault, fracturing, fluid circulation, and the process of precipitation and growth of calcite (Ramsay, 1980; Barker et al., 2006; Nuriel et al., 2011), geochemical, microstructural and petrographic analyses should be integrated into the $\mathrm{U}-\mathrm{Pb}$ geochronology of calcite minerals (cf. Nuriel et al., 2011; Miranda et al., 2020).

Low-temperature thermochronometers ((U-Th)/He and fission track) (Table 2) have been used in fault zones that show fluid circulation along the damage zones and in the core of the structure, these generally synkinematic upon the deformational event and characterized by the precipitation of hematite, magnetite and goethite in veins, breccias, and as patina along the sliding planes (cf. Tagami and Murakami, 2007; Wolfler et al., 2010; Gorynski et al., 2014; Hickey et al., 2014; Reiner et al., 2014; MacNamee and Stockli, 2015; Ault et al., 2016; Louis et al., 2019; Tagami, 2019). Under these conditions, the occu- rrence of iron oxides is the deformation dating target, these also record the temperatures in which the displacement of the structure was induced (cf. Wernicke and Lippolt, 1997; Shuster et al., 2005; Blackburn et al., 2007; Farley and Flowers, 2012; Evenson et al., 2014; Monteiro et al., 2014; Farley and McKeon, 2015; Ault et al., 2015, 2016; Cooperdock and Stockli, 2016; Miller et al., 2017; McDermott et al., 2017; Moser et al., 2017; García et al., 2018; Calzolari et al., 2018; Ault, 2020).

Other techniques applied to fault zones that present fluid circulation and that host mineralizations are dating of U-Th$\mathrm{Pb}$ in hydrothermal monazite (cf. Bergemann et al., 2017, 2018; Ricchi, Bergemann et al., 2020; Ricchi, Gnos et al., 2020; Prent et al., 2020), Rb-Sr in feldspar crystals (cf. Tillberg et al., 2017; Tillberg et al., 2020), and Re-Os in hydrothermal sulfides (Vernon et al., 2014; Lawley et al., 2013; Dichiarante et al., 2016).

For fault gouge, the method of dating by electron spin resonance (ESR) has been used for quartz grains that make up this non-cohesive rock (Table 2) (cf. Ikeya et al. 1982; Ikeya, 1993; Lee and Schwarcz, 1994; Lee and Yang, 2007). The technique is based on the ability to analyze damage caused by natural radiation in geological and biological materials such as shells, corals, bones and fossilized teeth, by detecting alpha, beta and gamma radioactivity from the sample and its environment (Duval et al., 2011; Duval, 2018). This radiation produces defects in the crystal lattice that can trap electrical charges that eventually form a "paramagnetic center" that produces a detectable signal in ESR spectrometry. The height (intensity) of the spectrum obtained is proportional to the number of electrons trapped in each paramagnetic center, the radiation dose and its duration (Ikeya et al., 1982; Ikeya, 1993, Grün, 1989; Lee and Schawarcz, 1994; Lee and Yang, 2007; Qju et al., 2018; Duval, 2018).

In shear zones that exhibit deformations of the brittle-ductile transition, which include associations of cataclasites, phyllonites, protomylonites and pseudotaquilites (Sibson, 1983; Simpson, 1986), as well as mineral reactions and fluids, the ArAr isotopic system in micas and the pseudotaquilite matrix is the most widely used tool for absolute dating of deformational activity (Crone, 1996; Vinasco, 2001; Oyhantçabal et al., 2012; Bense et al., 2014; Süssenberger et al., 2017). This is because of substantial retentiveness of Ar in the structure of neoformed minerals (closed isotopic system) (Purdy and Jäger, 1976; Reddy and Potts, 1999; Harrison et al., 2009) in intervals of low-to-medium temperature, conditions in which the reactivation of structures normally occurs (Grégoire et al., 2009; Webb et al., 2010; Bonamici et al., 2004; Oriolo et al., 2016a). When 
pseudotaquilites are processed, it is recommended to exclude clasts present in the matrix, since they can contribute foreign Ar derived from preexistent rock, which can yield ages without geological sense (Di Vincenzo et al., 2004).

The deformation age under middle crust conditions, mainly affected by the ductile regime, is traditionally determined by fine muscovites and neoformed biotites (cf. Freeman et al., 1998; Fossen and Dunlap; 1998; Müller et al., 2000; Vinasco, 2001; Whitmeyer, 2008, Vinasco and Cordani, 2012), and recrystallized minerals (cf. Kligfield et al., 1986; Oriolo et al., 2015,2016 b) (Table 2), which provide information on tectonic activation from cooling ages or isotopic resetting, given the low closure temperature of these isotopic systems (cf. van der Pluijm et al., 1994).

Nevertheless, there are debates about the meaning of the geochronological data of these isotopic methods when diffusion, dissolution and precipitation processes by creep processes and fluid-assisted recrystallization have developed in the fault rocks. This is because the age intervals obtained would be related to cooling processes of the system and not be directly related to the deformation timing (cf. Harrison et al., 1985; Jenkin, 1997; Carreras et al., 2013; Eberlei et al., 2015; Vissers et al., 2016; Druguet et al., 2018). For these conditions, in order to constrain the thermal history in the shear zone, in-situ $\mathrm{Rb}-\mathrm{Sr}$ and Ar-Ar micas and U-Th-Pb zircon, monazite, titanite, rutile and apatite have been integrated. The latter are resistant to physical and chemical alterations of the system, and in which the reported ages are related to crystallographic deformation process@, since the migration and formation of crystalline faces are subject to development without incorporation of radiogenic $\mathrm{Pb}$ in the crystal lattice (Dahl, 1997; Lee et al., 1997; Cherniak and Watson, 2000; Santos et al., 2003; Cherniak et al., 2004; Cocherie et al., 2005; Dahl et al., 2005; Harley et al., 2007; Reddy et al., 2007; Timms et al., 2011; Oyhantçabal et al., 2012; Bonamici et al., 2015; Erickson et al., 2015; Oriolo et al., 2016a; Kirkland et al., 2018 a, b; Giraldo et al., 2019; Odlum and Stockli, 2020; Ribeiro et al., 2020 a, b; Van Daele et al., 2020).

\subsubsection{Considerations for mineral dating of fault rocks}

For analysis and application of different isotopic systems is necessary to consider the closure temperatures of the minerals. This is because once the isotopic system has reached a specific temperature range, the host mineral does not exchange isotopes with the system (a closed isotopic system), so negligible diffusion rates are obtained, as therefore precise chronologi- cal information on the deformation event (cf. Dodson, 1973; Villa, 2002; Braun et al., 2006). Closure temperatures depend on physical factors such as grain size, mineral composition, cooling rate, and pressure, among others (cf. Dodson, 1973; Hames and Bowring, 1994; Grove and Harrison, 1996; Cherniak, 1995; Farley, 2000; Jenkin et al., 2001; Braun et al., 2006; Harrison et al., 2009). For this reason, to date fault rocks, it is necessary to rely on the reconstruction of geothermobarometric diagrams (P-T-t), geochemical analysis, thermodynamic modeling, and microstructural studies (cf. van der Plujim et al., 1994; Stünitz, 1998; Steffen and Selverstone, 2006; Villa et al., 2014; Odlum and Stockli, 2020; Ribeiro et al., 2020 a, b).

The temperature reached during the deformation process must be less than or equal to the closure temperature of the isotopic system of the geochronological method used. Otherwise, the age obtained will be a cooling age of the isotopic system and not of the deformation (Vinasco, 2001). This is because dynamic recrystallization, neo-crystallization, metamorphic reactions and fluid circulation (dissolution-precipitation processes) take place during deformation, which modify the physical properties (reset) of the isotopic system of minerals in fault rocks (cf. Dunlap, 1997; Villa, 2002; Mulch et al., 2002; Mulch and Cosca, 2004; Harley et al., 2007; Cosca et al., 2011; Tagami, 2012; Harlov, 2015; Oriolo et al., 2016a).

In the case of $\mathrm{U}-\mathrm{Pb}$ dating of carbonates (e.g., calcite), once the event of interest has been identified through field observations, petrography, cathodoluminescence and electron microscopy, one should confirm that: 1) the carbonate is contemporary or synchronous, or very close, to the geological event of interest; 2) the carbonate formed rapidly and under conditions that allowed enrichment in $\mathrm{U}$ and exclusion of $\mathrm{Pb} ; 3$ ) there is no evidence of dissolution,recrystallization, or alteration (e.g., diagenetic); 4) there are no different generations of carbonate; 5) there are optimal concentrations of $U$ in the mineral to ensure accurate dating, which can be determined by compositional maps (cf. Rasbury and Cole, 2009; Roberts and Walker, 2016; Roberts, 2019; Roberts et al., 2020a).

\subsection{Radiometric dating of geological features adjacent to shear zones}

Given the different geological processes (deformation, metamorphism, and fluid-rock interaction) related to the evolution of a shear zone, it is necessary to integrate geochronological and thermochronological studies of syntectonic elements of the structure, in order to constrain the age of deformation in 
shear zones (Fossen and Tikoff, 1997; Xypolias and Kokkalas, 2006; Vitale and Mazzoli, 2008; Carreras et al., 2013; Pennacchioni and Zucchi, 2013; Ribeiro et al., 2020b). These studies include:

a) Intrusive synkinematic (Table 3), which correspond to igneous bodies emplaced during reactivation episodes of fault systems, in which magmatic units are transported through the crust by shear zones that behave as channels connecting magma generation areas with the upper crust (D'Lemos et al., 1992; Reavy, 1989; Clemens and Mawer, 1992; Rosenberg, 2004). The emplacement of granitoids thus marks a direct relationship between tectonic deformation and magmatic bodies (D'Lemos et al., 1992; Druguet and Hutton, 1998; Brown and Solar, 1999; Grocott and Taylor, 2002; Vinasco and Cordani, 2012; Ávila et al., 2019) and delimits strongly deformed areas in which igneous bodies fill open spaces within brittle-ductile transition zones, mainly associated with transtensional deformations and limited by the traces of regional faults. To date these intrusives, it is necessary to perform a priori detailed analysis of magmatic fabrics (cf. Romn-Berdiel et al., 1997; Blumenfeld and Bouchez, 1988; Paterson et al., 1989; Bouchez et al., 1992; Paterson and Vernon, 1995; Paterson et al., 1998), in order to discriminate between pre-, syn- and postkinematic igneous bodies (Steenken et al., 2000; Rosenberg, 2004; Siegesmund et al., 2004; Wang et al., 2009; Oyhantçabal et al., 2009). Once determined from the magmatic fabric that the igneous body is synkinematic, the igneous units are dated by $\mathrm{U}-\mathrm{Pb}$ dating of zircon, in order to obtain the age of emplacement of the igneous body, information directly related to reactivation periods of the shear zone.

b) Hydrothermally altered rocks related to shear zone activity (Table 3), for which the Ar-Ar dating method is mainly used for neoformed white micas, which provide information on tectonic reactivations, because they are related to fluids generated during deformational events in the shear zones (Vinasco, 2001; Vinasco and Cordani, 2012). c) Blocks adjacent to the structure (Table 3) in which the exhumation ages are related to periods of deformation or reactivation of the fault zone, because low-temperature thermochronology dates the cooling ages, which in shear zone contexts are widely related to timing of the fault slip (cf. van der Pluijm et al., 1994; Stockli et al., 2002; Wells et al., 2000; Echler and Farley, 2003; Colgan et al., 2008; Bidgoli et al., 2015; Curry et al., 2016; Oriolo et al., 2016b; Abbey and Niemi, 2018; Collett et al., 2019; Heineke et al., 2019; Amaya-Ferreira et al., 2020). Exhumation ages are determined using low-temperature thermochronology methods (surface conditions of the lithosphere at $\sim 10-\mathrm{km}$ depth, for a normal geothermal gradient), including thermochronometers such as apatite fission track (AFT) and zircon fission track (ZFT), which give closing temperatures between $\sim 110-120^{\circ} \mathrm{C}$ and $\sim 230-240{ }^{\circ} \mathrm{C}$, respectively, under conditions of constant cooling and relatively rapid exhumation (Zaun and Wagner, 1985; Hurford, 1986; Laslett et al., 1987; Brandon and Vance, 1992, Ketcham et al., 1999; Bernet et al., 2002; Bernet et al., 2019).

\section{Conclusions And ReCOMmendations}

For geological-structural mapping of shear zones, it is suggested to perform an analysis of photointerpretation and geoprocessing of images in which the trace of the structure is preliminarily delimited. Once defined, field transects must be made perpendicular to the strike of the deformed area in order to collect structural data with statistical representativeness and determine the distribution, kinematics and geometry of the central and marginal areas of the principal structure in the shear zone, as well as of satellite faults, branches and secondary structures, in order to define the timing of deformation events and rank the developed structures.

To classify fault rocks in the field, it is recommended to adopt the modified proposal of Sibson (1977; 1979), Scholz (1988), Snoke et al. (1998), Killick (2003), Woodcock and Mort (2008) and Magloughlin (2010), which differentiated between cohesive and non-cohesive rocks, categorizes the rocks

Table 3. Synthesis of the material and proposed method for dating geological elements adjacent to the shear zone, as well as the information obtained thereby

\begin{tabular}{ccc}
\hline Material for dating & Proposed methods for dating & Informaction obtained \\
Zircons of synkinematic intrusive & U-Pb & Age of emplacement \\
$\begin{array}{c}\text { Neoformed micas of hydrothermally altered rocks } \\
\text { Fission tracks in apatite and zircon of blocks adjacent to the } \\
\text { structure }\end{array}$ & Ar-Ar & Age of reactivation of shear zone, cooling or isotopic resetting \\
\hline
\end{tabular}


according to the percentage of original and matrix grains, and describes the characteristics and deformation mechanisms developed during the deformation event.

The proposed methodology to determine and constrain the period of deformation in shear zones uses technical differences according to the deformational regime in which the fault rocks were generated, implements materials and methods of geological elements adjacent to the shear zone, and it is constituted by the following activities: 1) submicroscopic analysis of minerals; 2) dating of neoformed micas, fault gouge, and pseudotakylite matrix by the Ar-Ar method, and of calcite fibers and iron precipitates by the U-Pb and (U-Th)/He systems, respectively, under conditions of brittle/brittle-ductile deformation; 3) in-situ $\mathrm{K}-\mathrm{Ar}$ dating of micas and $\mathrm{U}-\mathrm{Th}-\mathrm{Pb}$ of pre- and synkinematic minerals in mylonite rocks; 4) dating of synkinematic intrusives, adjacent blocks, and hydrothermally altered rocks by the $\mathrm{U}-\mathrm{Pb}, \mathrm{AFT} / \mathrm{ZFT}$ and Ar-Ar methods, respectively.

The minerals that make up fault rocks are formed in the presence of fluids and conditions of varying pressure and temperature, and can be isotopic resetting during the evolutionary history of shear zones. Considering that the dating of fault rocks depends on the deformation temperature, it is suggested to establish the temperature from geothermometers and microscopic analysis of the microstructures. However, the presence of retrograde, recrystallization or dissolution-precipitation processes must be determined, since these processes substantially affect the closure temperature of the minerals used in the geochronological and thermochronological methods implemented and do not guarantee a closed isotopic system with negligible diffusion rates.

\section{ACKNOWLEDGEMENTS}

This contribution was made in the framework of the Tectonic Model project of Colombia, of the Tectonic Group of the Dirección de Geociencias Básicas of the Servicio Geológico Colombiano, in compliance with its mission related to comprehensive management of geoscientific knowledge. The authors thank the Geodynamics Research Group of the Tectonics Group and geologists Jairo Alonso Osorio, Yadira Rodríguez, Edward Salazar Ortiz and Ana Milena Suárez for their suggestions, as well as the anonymous reviewers for their technical contributions and constructive feedback.

\section{References}

Abbey, A. L., \& Niemi, N. A. (2018). Low-temperature thermochronometric constraints on fault initiation and growth in the northern Rio Grande rift, upper Arkansas River valley, Colorado, USA. Geology, 46(7), 627-630. https:/doi. org/10.1130/G40232.1

Aitken, A. R. A., \& Betts, P. G. (2009). Multi-scale integrated structural and aeromagnetic analysis to guide tectonic models: An example from the eastern Musgrave Province, Central Australia. Tectonophysics, 476(3-4), 418-435. https://doi.org/10.1016/j.tecto.2009.07.007

Altenberger, U., \& López I., J. A. (2014). Evidence of frictional melts in weak carbonate rocks: Examples from the Cuisa Fault, alta Guajira/Northern Colombia. Geología Colombiana, 37, 5-14.

Amaya-Ferreira, S., Zuluaga, C. A., \& Bernet, M. (2020). Different levels of exhumation across the Bucaramanga Fault in the Cepitá area of the southwestern Santander Massif, Colombia: Implications for the tectonic evolution of the northern Andes in northwestern South America. In J. Gómez \& D. Mateus Zabala (eds.), The geology of Colombia. Vol. 3: Paleogene-Neogene. Publicaciones Geológicas Especiales, 37. Servicio Geológico Colombiano. https://doi.org/10.32685/pub.esp.37.2019.17

Anderson, L. J., Osborne, R. H., \& Palmer, D. F. (1993). Cataclastic rocks of the San Gabriel Fault: An expression of deformation at deeper crustal levels in the San Andreas fault zones. Tectonophysics, 98(3-4), 209-251. https://doi. org/10.1016/0040-1951(83)90296-2

Angelier, J. (1979). Determination of the mean principal directions of stresses for a given fault population. Tectonophysics, 56(3-4), 17-26. https://doi.org/10.1016/0040-1951 (79)90081-7

Angelier, J. (1994). Fault slip analysis and palaeostress reconstruction. In P. L. Hancock (ed.), Continental deformation (pp. 53-100). Pergamon Press.

Angelier, J. T., \& Mechler, P. (1977). Sur une méthode graphique de recherche des contraintes principales également utilisables en tectonique et en séismologie: La méthode des dièdres droits. Bulletin de la Société Géologique de France, 7(6), 1309-1318.

Angiboust, S., Kirsch, J., Oncken, O., Glodny, J., Monié, P., \& Rybacki, E. (2015). Probing the transition between seismically coupled and decoupled segments along an ancient subduc- 
tion interface. Geochemistry, Geophysics, Geosystems, 16(6), 1905-1922. https://doi.org/10.1002/2015GC005776

Armit, R. J., Ailleres, L., Betts, P. G., Schaefer, B. F., \& Blaikie, T. N. (2014). High-heat geodynamic setting during the Paleozoic evolution of the Mount Painter Province, SA, Australia: Evidence from combined field structural geology and potential-field inversions. Geophysical Journal International, 199(1), 253-275. https://doi.org/10.1093/gji/ggu263

Ault, A. K. (2020). Hematite fault rock thermochronometry and textures inform fault zone processes. Journal of Structural Geology, 133, 104002. https://doi.org/10.1016/j. jsg.2020.104002

Ault, A. K., Frenzel, M., Reiners, P. W., Woodcock, N. H., \& Thomson, S. N. (2016). Record of paleofluid circulation in faults revealed by hematite (U-Th)/He and apatite fission-track dating: An example from Gower Peninsula fault fissures, Wales. Lithosphere, 8(4), 379-385. https://doi. org/10.1130/L522.1

Ault, A. K., Reiners, P. W., Evans, J. P., \& Thomson, S. N. (2015). Linking hematite (U-Th)/He Utah, USA. Geology, 43(9), 771-774. https://doi.org/10.1130/G36897.1

Ávila, C., Archanjo, C., Fossen, H., \& Hollanda, M. H. (2019). Zippered shear zone model for interacting shear zones in the Borborema Province, Brazil, as constrained by U-Pb dating. Tectonics, 38(10). https://doi. org/10.1029/2019TC005547

Babaie, H. A., Babaei, A., \& Hadizadeh, J. (1991). Initiation of cataclastic flow and development of cataclastic foliation in nonporous quartzites from a natural fault zone. Tectonophysics, 200(1-3), 67-77. https://doi.org/10.1016/00401951(91)90006-e

Babaie, H. A., \& La Tour, T. E. (1993). Semibrittle and cataclastic deformation of hornblende-quartz rocks in a ductile shear zone. Tectonophysics, 229(1-2), 19-30. https://doi. org/10.1016/0040-1951(94)90003-5

Balsamo, F., Storti, F., Salvini, F., Silva, A. T., \& Lima, C. C. (2010). Structural and petrophysical evolution of extensional fault zones in low-porosity, poorly lithified sandstones of the Barreiras Formation, NE Brazil. Journal of Structural Geology, 32(11), 1806-1826. https://doi.org/10.1016/j. jsg.2009.10.010

Barão, L. M., Trzaskos, B., Angulo, R. J., \& De Souza, M. C. (2018). Análise qualitative fractal das estruturas nas Ilhas Belmonte e Challenger e sua relação com a estruturação local: Arquipélago de São Pedro e São Paulo. In J. E. Lins
Oliveira, D. de L. Viana, M. A. Carvalho de Sousa (eds.), Arquipélago de São Pedro e São Paulo: 20 anos de pesquisa (pp. 221-224). Via Design Publicações.

Barão, L. M., Trzaskos, B., Angulo, R. J., \& De Souza, M. C. (2020). Deformation and structural evolution of mantle peridotites during exhumation on transform faults: A forced transition from ductile to brittle regime. Journal of Structural Geology, 133, 103981. https://doi.org/10.1016/j. jsg.2020.103981

Barker, S. L. L., Cox, S. F., Eggins, S. M., \& Gagan, M. K. (2006). Microchemical evidence for episodic growth of antitaxial veins during fracture-controlled fluid flow. Earth and Planetary Science Letters, 250(1-2), 331-344. https://doi.org/10.1016/j.epsl.2006.07.051

Bastesen, E., \& Braathen, A. (2010). Extensional faults in fine grained carbonates: Analysis of fault core lithology and thickness-displacement relationships. Journal of Structural Geology, 32(11), 1609-1628. https://doi.org/10.1016/j. jsg.2010.09.008

Beach, A., Welbon, A. I., Brockbank, P. J., \& McCallum, J. E. (1999). Reservoir damage around faults: Outcrop examples from the Suez Rift. Petroleum Geoscience, 5(2), 109-116. https://doi.org/10.1144/petgeo.5.2.109

Beam, E. C., \& Fisher, D. M. (1999). An estimate of kinematic vorticity from rotated elongate porphyroblasts. Journal of Structural Geology, 21(11), 1553-1559. https://doi. org/10.1016/S0191-8141(99)00110-8

Beaudoin, N., Lacombe, O., Roberts, N. M., \& Koehn, D. (2018). U-Pb dating of calcite veins reveals complex stress evolution and thrust sequence in the Bighorn Basin, Wyoming, USA. Geology, 46(11), 1015-1018. https://doi. org/10.1130/G45379.1

Behrmann, J. H., \& Mainprice, D. (1987). Deformation mechanisms in a high-temperature quartz-feldspar mylonite: Evidence for superplastic flow in the lower continental crust. Tectonophysics, 140(2-4), 297-305. https://doi. org/10.1016/0040-1951(87)90236-8

Bell, T. H., \& Etheridge, M. A. (1973). Microstructure of mylonites and their descriptive terminology. Lithos, 6(4), 337348. https://doi.org/10.1016/0024-4937(73)90052-2

Bella, B. E. N., Njanko, T., \& Tchakounte, J. (2019). CPO and kinematic analysis of the Bitou S-tectonites (Central Camerrom shear zone): AMS and EBSD investigations. Journal of Earth System Science, 128(231), 1-14. https://doi. org/10.1007/s12040-019-1264-9 
Bense, F. A., Wemmer, K., Löbens, S., \& Siegesmund, S. (2014). Fault gouge analyses: K-Ar illite dating, clay mineralogy and tectonic significance: a study from the Sierras Pampeanas, Argentina. International Journal of Earth Sciences, 103, 189-218. https://doi.org/10.1007/s00531-013-0956-7

Berg, S. S., \& Skar, T. (2005). Controls on damage zone asymmetry of a normal fault zone: Outcrop analyses of a segment of the Moab fault, SE Utah. Journal of Structural Geology, 27(10), 1803-1822. https://doi.org/10.1016/j.jsg.2005.04.012

Bergemann, C. A., Gnos, E., Berger, A., Whitehouse, M. J., Mullis, J., Wehrens, P., Pettke, T., \& Janots, E. (2017). Th- $\mathrm{Pb}$ ion probe dating of zoned hydrothermal monazite and its implications for repeated shear zone activity: An example from the Central Alps, Switzerland. Tectonics, 36(4), 671689. https://doi.org/10.1002/2016TC004407

Bergemann, C. A., Gnos, E., Berger, A., Whitehouse, M. J., Mullis, J., Walter, F., \& Bojar, H. P. (2018). Constraining long-term fault activity in the brittle domain through in situ dating of hydrothermal monazite. Terra Nova, 30(6), 440-446. https://doi.org/10.1111/ter.12360

Bernet, M., Brandon, M. T., Garver, J. I., Reiners, P. W., \& Fitzgerald, P. G. (2002). Determining the zircon fission-track closure temperature. GSA Cordilleran Section, $98^{\text {th }}$ annual meeting, Abstract with Programs (34), 18.

Bernet, M., Piraquive, A., Urueña, C., López-Isaza, J., Bermúdez, M., Zuluaga, C., Amaya, S., \& Villamizar, N. (2019). Multidisciplinary petro-geo-thermochronological approach to ore deposit exploration. Ore Geology Reviews, 112, 103017. https://doi.org/10.1016/j.oregeorev.2019.103017

Betts, P. G., Valenta, R. K., \& Finlay, J. (2003). Evolution of the Mount Woods Inlier, northern Gawler Craton, Southern Australia: An integrated structural and aeromagnetic analysis. Tectonophysics, 366(1-2), 83-111. https://doi. org/10.1016/S0040-1951(03)00062-3

Bidgoli, T. S., Stockli, D. F., \& Walker, J. D. (2015). Low-temperature thermochronologic constraints on the kinematic histories of the Castle Cliffs, Tule Springs, and Mormon Peak detachments, southwestern Utah and southeastern Nevada. Geosphere, 11(3), 850-867. https://doi.org/10.1130/ GES01083.1

Billi, A., Salvini, F., \& Storti, F. (2003). The damage zone-fault core transition in carbonate rocks: Implications for fault growth, structure and permeability. Journal of Structural Geology, 25(11), 1779-1794. https://doi.org/10.1016/ S0191-8141(03)00037-3
Blackburn, T. J., Stockli, D. F., \& Walker, J. D. (2007). Magnetite (U-Th)/He dating and its application to the geochronology of intermediate to mafic volcanic rocks. Earth and Planetary Science Letters, 259(3-4), 360-371. https://doi. org/10.1016/j.epsl.2007.04.044

Blaikie, T. N., Ailleres, L., Betts, P. G., \& Cas, R. A. F. (2014). Interpreting subsurface volcanic structures using geologically constrained 3-D gravity inversions: Examples of maar-diatremes, Newer Volcanics Province, southeastern Australia. Journal of Geophysical Research: Solid Earth, 119(4), 38573878. https://doi.org/10.1002/2013JB010751

Blaikie, T. N., Betts, P. G., Armit, R. J., \& Ailleres, L. (2017). The ca. 1740-1710 Ma Leichhardt Event: Inversion of a continental rift and revision of the tectonic evolution of the North Australian Craton. Precambrian Research, 292, 75-92. https://doi.org/10.1016/j.precamres.2017.02.003

Blenkinsop, T. (2002). Deformation microstructures and mechanism in mineral and rocks. Klewer Academic Publishers.

Blenkinsop, T., \& Rutter, E. (1986). Cataclastic deformation of quartzite in the moine thrust zone. Journal of Structural Geology, 8(6), 669-681. https://doi.org/10.1016/01918141(86)90072-6

Blumenfeld, P., \& Bouchez, J. L. (1988). Shear criteria in granite and migmatite deformed in the magmatic and solid states. Journal of Structural Geology, 10(4), 361-312. https://doi. org/https://doi.org/10.1016/0191-8141(88)90014-4

Bohlen, S. R., \& Lindsley, D. H. (1987). Thermobarometry and barometry of igneous and metamorphic rocks. Annual Reviews in Earth and Planetary Sciences, 15, 397-420.

Bonamici, C. E., Fanning, C. M., Kozdon, R., Fournelle, J. H., \& Valley, J. W. (2015). Combined oxygen-isotope and U-Pb zoning studies of titanite: New criteria for age preservation. Chemical Geology, 398, 70-84. https://doi.org/10.1016/j. chemgeo.2015.02.002

Bonamici, C. E., Kozdon, R., Ushikubo, T., \& Valley, J. W. (2014). Intragrain oxygen isotope zoning in titanite by SIMS: Cooling rates and fluid infiltration along the CarthageColton Mylonite Zone, Adirondack Mountains, NY, USA. Journal of Metamorphic Geology, 32(1), 71-92. https://doi.org/10.1111/jmg.12059

Borradaile, G. J., \& Werner, T. (1994). Magnetic anisotropy of some phyllosilicates. Tectonophysics, 235(3), 223-248. https://doi.org/10.1016/0040-1951(94)90196-1

Bossi, J., \& Campal, N. (1992). Magmatismo y tectónica transcurrente durante el Paleozoico inferior del Uruguay. In 
J. Gutiérrez, J. Saavedr, \& I. Rábano (eds.), Paleozoico Inferior de Ibero-América (pp. 343-356). Universidad de Extremadura, Alicante.

Bott, M. (1959). The mechanics of oblique slip faulting. Geological Magazine, 96(2), 109. https://doi.org/10.1017/ S0016756800059987

Bouchez, J. L., Delas, C., Gleizes, G., \& Nédélec, A. (1992) Submagmatic microfractures in granites. Geology, 20(1), 35-38. https://doi.org/10.1130/0091-7613(1992)020<0035:SMI$\mathrm{G}>2.3 . \mathrm{CO} ; 2$

Brandon, M. T., \& Vance, J. A. (1992). Tectonic evolution of the Cenozoic Olympic subduction complex, Washington State, as deduced from fission track ages for detrital zircons. American Journal of Science, 292(8), 565-636.

Brodie, K., Fettes, D., Harte, B., \& Schmid, R. (2007). Structural terms including fault rock terms. From IUGS Subcomission on the Systematics of Metamorphic Rocks (SCMR).

Brown, M., \& Solar, G. S. (1998). Shear-zone systems and melts: Feedback relations and self-organization in orogenic belts. Journal of Structural Geology, 20(2-3), 211-227. https://doi. org/10.1016/S0191-8141(97)00068-0

Brown, M., \& Solar, G. S. (1999). The mechanism of ascent and emplacement of granite magma during transpression: A syntectonic paradigm. Tectonophysics, 312(1), 1-33. https:// doi.org/10.1016/S0040-1951(99)00169-9

Bull, W. B. (2007). Tectonic geomorphology of mountains: A new approach to paleoseismology. Blackwell Publishing. https:// doi.org/10.1016/S0040-1951(99)00169-9

Burkhard, M. (1993). Calcite twin, their geometry, appearance and significance as strain-stress markers and indicators of tectonic regime: A review. Journal of Structural Geology, 15(35), 351-368. https://doi.org/10.1016/0191-8141(93)90132-T

Burrbank, D. W., \& Anderson, R. S. (2011). Tectonic geomorphology (2nd ed.). Wiley-Blackwell.

Caine, J. S., Coates, D. R., Timoffeef, N. P., \& Davis, W. D. (1991). Hydrogeology of the Northern Shawangunk Mountains. New York State Open-File Report 1, 806.

Caine, J. S., Evans, J. P., \& Forster, C. B. (1996). Fault zone architecture and permeability structure. Geology, 24(11), 10251028. https://doi.org/10.1130/0091-7613(1996)024<1025:FZAAPS $>2.3 . \mathrm{CO} ; 2$

Calzolari, G., Rossetti, F., Ault, A. K., Lucci, F., Olivetti, V., \& Nozaem, R. (2018). Hematite (U-Th)/He thermochronometry constrains strike-slip faulting on the Kuh-e-Faghan fault, central Iran. Tectonophysics, 728-729, 41-54. https:// doi.org/10.1016/j.tecto.2018.01.023

Cao, S., Neubauer, F., Liu, J., Bernroider, M., Cheng, X., Li, J., Yu, Z., \& Genser, J. (2017). Rheological weakening of highgrade mylonites during low-temperature retrogression: The exhumed continental Ailao Shan-Red River fault zone, SE Asia. Journal of Earth Sciences, 139, 40-60. https://doi. org/10.1016/j.jseaes.2016.10.002

Carreras, J., Cosgrove, J. W., \& Druguet, E. (2013). Strain partitioning in banded and/or anisotropic rocks: Implications for inferring tectonic regimes. Journal of Structural Geology, 50, 7-21. https://doi.org/10.1016/j.jsg.2012.12.003

Casas, A., Peña, I., \& Simón, J. (1990). Los métodos de análisis de paleoesfuerzos a partir de poblaciones de fallas: Sistemática y técnicas de aplicación. Estudios Geológicos, 46(56), 385-398. https://doi.org/10.3989/egeol.90465-6469

Cassata, W. S., Renne, P. R., \& Shuster, D. L. (2009). Argon diffusion in plagioclase and implications for thermochronometry: A case of study from the Bushveld Complex, South Africa. Geochimica et Cosmochimica Acta, 73(21), 6600-6612. https://doi.org/10.1016/j.gca.2009.07.017

Cavalcante, C., Lagoeiro, L., Fossen, H., Egydio Silva, M., Morales, L. F. G., Ferrerira, F., \& Conte, T. (2018). Temperature constraints on microfabric patterns in quartzofeldsphatic mylonites, Ribeira belt (SE Brazi). Journal of Structural Geology, 115, 243-262. https://doi.org/10.1016/j. jsg.2018.07.013

Célérier, B. (1988). How much does slip on a reactived fault plane constrain the stress tensor? Tectonics, 7(6), 12571278. https://doi.org/10.1029/TC007i006p01257

Cello, G. (1997). Fractal analysis of a Quaternary fault array in the central Apennines, Italy. Journal of Structural Geology, 19(7), 945-953. https://doi.org/10.1016/s01918141(97)00024-2

Chan, Y.-C., Crespi, J. M., \& Hodges, K. V. (2000). Dating cleavage formation in slates and phyllites with the ${ }^{40} \mathrm{Ar} /{ }^{39} \mathrm{Ar}$ laser microprobe: An example from the western New England Appalachians, USA. Terra Nova, 12(6), 264-271. https://doi.org/10.1046/j.1365-3121.2000.00308.x

Chen, C.-L., \& Thomson, R. C. (2010). The combined use of EBSD and EDX analyses for the identification of complex intermetallic phases in multicomponent $\mathrm{Al}-\mathrm{Si}$ piston alloys. Journal of Alloys and Compounds, 490(1-2), 293-300. https://doi.org/10.1016/j.jallcom.2009.09.181 
Chen, R.-F., Lin, C.-W., Chen, Y.-H., He, T.-C., \& Fei, L.-Y. (2015). Detecting and characterizing active thrust fault and deep-seated landslides in dense forest areas of southern Taiwan using airborne LiDAR DEM. Remote Sensing, 7(11), 15443-15466. https://doi.org/10.3390/rs71115443

Cherniak, D. J. (1995). Diffusion of lead in plagioclase and K-feldspar: An investigation using Rutherford backscattering and resonant nuclear reaction analysis. Contributions to Mineralogy and Petrology, 120, 358-371. https://doi. org/10.1007/BF00306513

Cherniak, D. J., \& Watson, E. B. (2000). Pb diffusion in zircon. Chemical Geology, 172(1-2), 5-24. https://doi.org/10.1016/ S0009-2541(00)00233-3

Cherniak, D. J., Watson, E. B., Grove, M., \& Harrison, T. M. (2004). Pb diffusion in monazite: A combined RBS/SIMS study. Geochimica et Cosmochimica Acta, 68(4), 829-840. https://doi.org/10.1016/j.gca.2003.07.012

Chester, F. M., \& Chester, J. S. (1998). Ultracataclasite structure and friction processes of the Punchbowl fault, San Andreas system, California. Tectonophysics 295(1-2), 199-221. https://doi.org/10.1016/S0040-1951(98)00121-8

Chester, F. M., Chester, J. S., Kirschner, D. L., Schulz, S. E., \& Evans, J. P. (2004). Structure of large-displacement, strikeslip fault zones in the brittle continental crust. In G. D. Karner, B. Taylor, N. W. Driscoll, \& D. L. Kohlstedt (eds.), Rheology and deformation in the lithosphere at continental margins. Columbia University Press.

Chester, F. M., Evans, J. P., \& Biegel, R. L. (1993). Internal structure and weakening mechanisms of the San Andreas fault. Journal of Geophysical Research, 98(B1), 771-786. https:// doi.org/10.1029/92JB01866

Chester, F. M., Friedman, M., \& Logan, J. M. (1985). Foliated cataclasites. Tectonophysics, 111(1-2), 139-146. https://doi. org/10.1016/0040-1951(85)90071-X

Chester, F. M., \& Logan, J. M. (1986). Composite planar fabric of gouge from the Punchbowl fault zone, California. Journal of Structural Geology, 9(5-6), 621-634. https://doi. org/10.1016/0191-8141(87)90147-7

Chetty, T. R. K. (2014). Deep crustal shear zones in the Eastern Ghats Mobile Belt, India: Gondwana correlations. The Journal Indian Geophysical Union, 18(1), 19-56.

Childs, C., Nicol, A., Walsh, J. J., \& Watterson, J. (1996). Growth of vertically segmented normal faults. Journal of Structural Geology, 18(12), 1389-1397. https://doi.org/10.1016/ S0191-8141(96)00060-0
Choi, J., Edwards, P., Ko, K., \& Kim, Y. (2016). Definition and classification of fault damage zones: A review and a new methodological approach. Earth-Science Reviews, 152, 7087. https://doi.org/10.1016/j.earscirev.2015.11.006

Clemens, J. D., \& Mawer, C. K. (1992). Granitic magma transport by fracture propagation. Tectonophysics, 204(3-4), 339-360. https://doi.org/10.1016/0040-1951(92)90316-X

Clerc, C., Jolivet, L., \& Ringenbach, J.-C. (2015). Ductile extensional shear zones in the lower crust of a passive margin. Earth and Planetary Science Letters, 431, 1-7. https://doi. org/10.1016/j.epsl.2015.08.038

Cocherie, A., Be Mezeme, E., Legendre, O., Fanning, C. M., Faure, M., \& Rossi, P. (2005). Electron-microprobe dating as a tool for determining the closure of Th- $\mathrm{U}-\mathrm{Pb}$ systems in migmatitic monazites. American Mineralogist, 90(4), 607618. https://doi.org/10.2138/am.2005.1303

Colgan, J. P., Shuster, D. L., \& Reiners, P. W. (2008). Two-phase Neogene extension in the northwestern basin and range recorded in a single thermochronology sample. Geology, 36(8), 631-634. https://doi.org/10.1130/G24897A.1

Collett, C. M., Duvall, A. R., Flowers, R. M., Tucker, G. E., \& Upton, P. (2019). The timing and style of oblique deformation within New Zealand's Kaikōura ranges and Marlborough fault system based on low-temperature thermochronology. Tectonics, 38(4), 1250-1272. https://doi. org/10.1029/2018TC005268

Conte, T., Cavalcante, C., Lagoeiro, L. E., Fossen, H., \& Silveira, C. S. (2020). Quartz textural analysis from an anastomosing shear zone system: Implications for the tectonic evolution of the Ribeira belt, Brazil. Journal of South American Earth Sciences, 103, 102750. https://doi.org/10.1016/j. jsames.2020.102750

Connolly, J. A. D. (2005). Computation of phase equilibria by linear programming: A tool for geodynamic modeling and its application to subduction zone decarbonation. Earth and Planetary Science Letters, 236(1-2), 524-541. https:// doi.org/10.1016/j.epsl.2005.04.033

Connolly, J. A. D. (2009). The geodynamic equation of state: What and how. Geochemistry, Geophysics, Geosystems, 10(10). https://doi.org/10.1029/2009GC002540

Cooperdock, E. H., \& Stockli, D. F. (2016). Unraveling alterations histories in serpentinites and associated ultramafic rocks with magnetite (U-Th)/He geochronology. Geology, 44(11), 967-970. https://doi.org/10.1130/G38587.1 
Cosca, M., Stünitz, H., Bourgeix, A.-L., \& Lee, J. P. (2011). Ar* loss in experimentally deformed muscovite and biotite with implications for ${ }^{40} \mathrm{Ar} /{ }^{39} \mathrm{Ar}$ geochronology of naturally deformed rocks. Geochimica et Cosmochimica Acta, 75(24), 7759-7778. https://doi.org/10.1016/j.gca.2011.10.012

Cosca, M. A., Caby, P., \& Bussya, F. (2005). Geochemistry and ${ }^{40} \mathrm{Ar} /{ }^{39} \mathrm{Ar}$ geochronology of pseudotachylite associated with UHP whiteschists from the Dora Maira massif, Italy. Tectonophysics, 402(1-2), 93-110. https://doi.org/10.1016/j. tecto.2004.12.033

Cox, S. F., Knackstedt, M. A., \& Braun, J. (2001). Principles of structural control on permeability and fluid flow in hydrothermal systems. In J. P. Richards, \& R. M. Tosdal (eds.), Reviews in Economic Geology, vol. 14, Structural controls on ore genesis. Society of Economic Geologists. https://doi. org/10.5382/Rev.14.01

Crone, A. J., \& Omdahl, E. M. (1987). Directions in Paleoseismology. U. S. Geological Survey, New Mexico.

Cross, A. J., Kidder, S., \& Prior, D. J. (2015). Using microstructures and TitaniQ thermobarometry of quartz sheared around garnet porphyroclasts to evaluate microstructural evolution and constrain an Alpine fault zone geotherm. Journal of Structural Geology, 75, 17-31. https://doi.org/10.1016/j.jsg.2015.02.012

Curry, M. A. E., Barnes, J. B., \& Colgan, J. P. (2016). Testing fault growth models with low-temperature thermochronology in the northwest basin and range, USA. Tectonics, 35(10), 2467-2492. https://doi.org/10.1002/2016TC004211

D’Lemos, R. S., Brown, M., \& Strachan R. A. (1992). Granite magma generation, ascent and emplacement with a transpresional orogen. Journal of the Geological Society, 149(4), 487-490. https://doi.org/10.1144/gsjgs.149.4.0487

Dahl, P. S. (1997). A crystal-chemical basis for $\mathrm{Pb}$ retention and fission-track annealing systematics in U-bearing minerals, with implications for geochronology. Earth and Planetary Science Letters, 150(3-4), 277-290. https://doi.org/10.1016/ S0012-821X(97)00108-8

Dahl, P. S., Terry, M. P., Jercinovic, M. J., Williams, M. L., Hamilton, M. A., Foland, K. A., Clement, S. M., \& Friberg, L. M. (2005). Electron probe (ultrachron) micronometry of metamorphic monazite: Unraveling the timing of polyphase thermotectonism in the easternmost Wyoming craton (Black Hills, South Dakota). American Mineralogist, 90(1112), 1712-1728. https://doi.org/10.2138/am.2005.2002
Davids, C., Wemmer, K., Zwingmann, H., Kohlmann, F., Jacobs, J., \& Bergh, S. G. (2013). K-Ar illite and apatite fission track constraints on brittle faulting and the evolution of the northern Norwegian passive margin. Tectonophysics, 608, 196-211. https://doi.org/10.1016/j.tecto.2013.09.035

Davis, G. H., \& Reynolds, S. J. (1996). Structural Geology of Rocks and Regions (2nd ed.). Wiley.

Davis, G. H., Reynolds, S. J., \& Kluth, C. F. (2011). Structural Geology of rocks and regions (3rd ed). Jhon Wiley \& Sons, INC.

De Capitani, C., \& Petrakakis, K. (2010). The computation of equilibrium assemblage diagrams with Theriak/Domino software. American Mineralogist, 95(7), 1006-1016. https:// doi.org/10.2138/am.2010.3354

Delvaux, D. (2012). Release of program Win-Tensor 4.0 for tectonic stress inversión: statistical expression of stress parameters. EGU General Assembly, Vienna. Geophysical Research Abstracts, 14, EGU2012-5899.

Delvaux, D., Kervyn, F., Macheyeki, A. S., \& Temu, E. B. (2012). Geodynamic significance of the TRM segment in the East African Rift (W-Tanzania): Active tectonics and paleostress in the Ufipa plateau and Rukwa basin. Journal of Structural Geology, 37, 161-180. https://doi.org/10.1016/j. jsg.2012.01.008

Delvaux, D., \& Sperner, B. (2003). New aspects of tectonic stress inversion with reference to the Tensor program (pp. 75-100). Special Publications vol. 212. Geological Society of London. https://doi.org/10.1144/GSL.SP.2003.212.01.06

Desbois, G., Hemes, S., Laurich, B., Houben, M., Klaver, J., Hohne, N., Urai, J. L., VIggiani, G., \& Bésuelle, P. (2016). Investigation of microstructures in naturally and experimentally deformed reference clay rocks using innovative methods in scanning electron microscopy. The Clay Minerals Society Workshop Lectures Series, 21(1), 1-14. https:// doi.org/10.1346/CMS-WLS-21.1

Despaigne Díaz, A. I., \& Cáceres, D. G. (2009). Las maclas de calcita en los metacarbonatos: Significado tectónico y su empleo para la determinación de temperaturas de deformación. Minería y Geología, 25(2), 1-31.

Dichiarante, A. M., Holdsworth, R. E., Dempsey, E. D., Selby, D., McCaffrey, K. J. W., Michie, U. M., Morgan, G., \& Bonniface, J. (2016). New structural and Re-Os geochronological evidence constraining the age of faulting and associated mineralization in the Devonian Orcadian basin, Scotland. Journal of the Geological Society, 173(3), 457-473. https:// doi.org/10.1144/jgs2015-118 
Di Vincenzo, G., Rocchi, S., Rossetti, F., \& Storti, F. (2004). ${ }^{40}$ Ar${ }^{39} \mathrm{Ar}$ dating of pseudotachylytes: the effect of clast-hosted extraneous argon in Cenozoic fault-generated friction melts from the West Antarctic Rift System. Earth and Planetary Science Letters, 223(3-4), 349-364. https://doi. org/10.1016/j.epsl.2004.04.042

Di Vincenzo, G., Rossetti, F., Viti, C., \& Balsamo, F. (2013). Constraining the timing of fault reactivation: Eocene coseismic slip along a Late Ordovician ductile shear zone (northern Victoria Land, Antarctica). Geological Society of America Bulletin, 125(3-4), 609-624. https://doi. org/10.1130/B30670.1

Doblas, M. (1998). Slickenside kinematic indicators. Tectonophysics, 295(1-2), 187-197. https://doi.org/10.1016/S00401951(98)00120-6

Doblas, M., Mahecha, V., Hoyos, M., \& López Ruiz, J. (1997). Slickenside and fault surface kinematic indicators on active normal faults of the Alpine Betic cordilleras, Granada, southern Spain. Journal of Structural Geology, 19(2), 159170. https://doi.org/10.1016/S0191-8141(96)00086-7

Dressel, B. C., Chauvet, A., Trzaskos, B., Biondi, J. C., Bruguier, O., Monié, P., Villavona, S. N., \& Newton, J. B. (2018). The Passa Três lode gold deposit (Paraná State, Brazil): An example of structurally-controlled mineralization formed during magmatic-hydrothermal transition and hosted within granite. Ore Geology Reviews, 102, 701-727. https:// doi.org/10.1016/j.oregeorev.2018.09.007

Druguet, E., Carreras, J., \& Mezger, J. E. (2018). Discussion on 'Middle Jurassic shear zones at Cap de Creus (eastern Pyrenees, Spain): a record of pre-drift extension of the Piemonte-Ligurian Ocean?' Journal of the Geological Society, London, 174, 289-300. Journal of the Geological Society, 175(1), 187-188. https://doi.org/10.1144/jgs2017-042

Druguet, E., \& Hutton, D. (1998). Syntectonic anatexis and magmatism in a mid-crustal transpresional shear zone: An example from the Hercynian rocks of the eastern Pyrenees. Journal of Structural Geology, 20(7), 905-916. https://doi. org/10.1016/S0191-8141(98)00017-0

Duba, A. G., Durham, W. B., Handin, J. W., \& Wang, H. F. (1990). The brittle-ductile transition in rocks. Geophysical Monograph Series 56. https://doi.org/10.1029/GM056

Dunlap, W. J. (1997). Neocrystallization or cooling? ${ }^{40} \mathrm{Ar} /{ }^{39} \mathrm{Ar}$ ages of white micas from low-grade mylonites. Chemical Geology, 143(3-4), 181-203. https://doi.org/10.1016/S00092541(97)00113-7
Duval, M. (2018). Sobre el potencial de la resonancia paramagnética electrónica como herramienta geocronológica en contextos geoarqueológicos: Un resumen de 30 años de investigación en la península ibérica. Boletín Geológico y Minero, 1129(1-2), 35-57. https://doi.org/10.21701/bolgeomin.129.1.002

Duval, M., Moreno, D., Shao, Q., Voinchet, P., Falguères, C., Bahain, J. J., García, T., García, J., \& Martínez, K. (2011). Datación por ESR del yacimiento arqueológico del Pleistoceno inferior de Vallparadís (Terrassa, Cataluña, España). Trabajos de Prehistoria, 68(1), 7-24. https://doi. org/10.3989/tp.2011.11056

Duvall, A. R., Clark, M. K., Van del Plujim, B. A., \& Li, C. (2011). Direct dating of Eocene reverse faulting in northeastern Tibet using Ar-dating of fault clays and low-temperature thermochronometry. Earth and Planetary Science Letters, 304(3-4), 520-526. https://doi.org/10.1016/j. epsl.2011.02.028

Eberlei, T., Habler, G., Wegner, W., Schuster, R., Körner, W., Thöni, M., \& Abart, R. (2015). Rb/Sr isotopic and compositional retentivity of muscovite during deformation. Lithos, 227, 161-178. https://doi.org/10.1016/j.lithos.2015.04.007

Ehlers, T. A., \& Farley, K. A. (2003). Apatite (U-Th)/He thermochronometry: Methods and applications to problems in tectonics and surface processes. Earth and Planetary Science Letters, 206(1-2), 1-14. https://doi.org/10.1016/S0012821X(02)01069-5

Engelder, J. T. (1974). Cataclasis and the generation of fault gouge. GSA Bulletin, 85(10), 1515-1522. https://doi.org/ 10.1130/0016-7606(1974)85<1515:CATGOF>2.0.CO;2

Erickson, T. M., Pearce, M. A., Taylor, R. J. M., Timms, N. E., Clark, C., Reddy, S. M., \& Buick, I. S. (2015). Deformed monazite yields high-temperature tectonic ages. Geology, 43(5), 383-386. https://doi.org/10.1130/G36533.1

Essene, E. J. (1989). The current status of thermobarometry in metamorphic rocks. In J. S. Daly, R. A. Cliff, \& B. W. D. Yardley (eds.). Evolution of metamorphic belts (pp. 1-44.). Special Publication, vol. 43. Geological Society of London. https://doi.org/10.1144/GSL.SP.1989.043.01.02

Evenson, N. S., Reiners, P. W., Spencer, J., \& Shuster, D. L. (2014). Hematite and Mn oxide (U-Th)/He dates from the Buckskin-Rawhide detachment system, western Arizona: Constraining the timing of mineralization and hematite (U-Th)/He systematics. American Journal of Science, 314(10), 1373-1435. https://doi.org/10.2475/10.2014.01 
Faleiros, F. M., Campanha, G. A. C., Bello, R. M. S., \& Fuzikawa, K. (2010). Quartz recrystallization regimes, c-axis texture transitions and fluid inclusion reequilibration in a prograde greenschist to amphibolite facies mylonite zone (Ribeira Shear Zone, SE Brazil). Tectonophysics, 485(1-4), 193-214. https://doi.org/10.1016/j.tecto.2009.12.014

Farley, K. A. (2000). Helium diffusion from apatite: General behavior as illustrated by Durango fluorapatite. Journal Geophysical Research, 105(B2), 2903-2914. https:/doi. org/10.1029/1999JB900348

Farley, K. A., \& Flowers, R. M. (2012). (U-Th)/Ne and multidomain $(\mathrm{U}-\mathrm{Th}) / \mathrm{He}$ systematics of a hydrothermal hematite from eastern Grand Canyon. Earth and Planetary Science Letters, 359-360, 131-140. https://doi.org/10.1016/j. eps1.2012.10.010

Farley, K. A., \& McKeon, R. E. (2015). Radiometic dating and temperature history of banded iron formation-associated hematite, Gogebic iron range, Michigan, USA. Geology, 43(12), 1083-1086. https://doi.org/10.1130/G37190.1

Faulkner, D. R., Jackson, C. A. L., Lunn, R. J., Schlische, R. W., Shipton, Z. K., Wibberley, C. A. J., \& Withjack, M. O. (2010). A review of recent developments concerning the structure, mechanics and fluid flow properties of fault zones. Journal Structural Geology, 32(11), 1557-1575. https://doi.org/10.1016/j.jsg.2010.06.009

Ferrill, D. A. (1991). Calcite twin widths and intensities as metamorphic indicators in natural low temperature deformation in limestone. Journal of Structural Geology, 13(6), 667675. https://doi.org/10.1016/0191-8141(91)90029-I

Ferrill, D. A., Morris, A. P., Evans, M. A., Burkhard, M., Groshong, R. H., \& Onasch, C. M. (2004). Calcite twin morphology: A low temperature deformation geothermometer. Journal of Structural Geology, 26(8), 1521-1529. https://doi. org/10.1016/j.jsg.2003.11.028

Fitz-Díaz, E., \& van der Plujim, B. (2013). Fold dating: A new Ar/Ar illite dating application to constrain the age of deformation in shallow crustal rocks. Journal of Structural Geology, 54, 174-179. https://doi.org/10.1016/j.jsg.2013.05.011

Flinn, D. (1979). The deformation matrix and the deformation ellipsoid. Journal of Structural Geology, 1(4), 299-307. https://doi.org/10.1016/0191-8141(79)90004-X

Forero-Ortega, A. J., Campanha, G. A. C., Faleiros, F. M., \& Yogi, M. T. A. G. (2020). Pure shear-dominated transpression and vertical extrusion in a strike-slip fault splay from the Itapirapuã Shear Zone, Ribeira Belt, Brazil. Tec- tonophysics, 786, 228455. https://doi.org/10.1016/j.tecto.2020.228455

Fossen, H. (2013). Structural geology. Cambridge University Press. Fossen, H., \& Cavalcante, G. C. G. (2017). Shear zones: A review. Earth-Science Reviews, 171, 434-455. https://doi. org/10.1016/j.earscirev.2017.05.002

Fossen, H., \& Dunlap, W. J. (1998). Timing and kinematics of Caledonian thrusting and extensional collapse, southern Norway: evidence from 40Ar/39Ar thermochronology. Journal of Structural Geology, 20(6), 765-781. https://doi. org/10.1016/S0191-8141(98)00007-8

Fossen, H., \& Tikoff, B. (1997). Forward modeling of nonsteady-state deformations and the "minimum strain path". Journal of Structural Geology, 19(7), 987-996. https://doi. org/10.1016/S0191-8141(97)00021-7

Freeman, S. B., Butler, R. W. H., Cliff, R. A., \& Rex, D. C. (1998). Direct dating of mylonite evolution: A multi-disciplinary geochronological study from the Moine thrust zone, NW Scotland. Journal of the Geological Society, 155(5), 745-758. https://doi.org/10.1144/gsjgs.155.5.0745

Fry, N. (2001). Stress space: Striated fault, deformation twins and their constraints on paleostress. Journal of Structural Geology, 23(1), 1-9. https://doi.org/10.1016/S0191-8141(00)00136-X

Gabrielsen, R. H., \& Braathen, A. (2014). Models of fracture lineaments: Joints swarms, fracture corridor and faults in crystalline rocks, and their generic relations. Tectonophysics, 628, 26-44. https://doi.org/10.1016/j.tecto.2014.04.022

Gabrielsen, R. H., Braathen, A., \& Ganerød, M. (2008). A reactivated fault system of southern Norway: How far east did the Mesozoic extension reach? International Geological Congress, Oslo, 4-15 August. Key note lecture, 33.

Gannouni, S., \& Gabtni, H. (2015). Structural interpretation of lineaments by satellite image processing (Landsat TM) in the region of Zahret Medien (Northern Tunisia). Journal of Geographic Information System, 7(2), 119-127. https://doi. org/10.4236/jgis.2015.72011

García, D. A. C. (2011). Caracterización de la deformación y metamorfismo de los esquistos de Sabaletas, parte norte de la cordillera Central de Colombia (Master thesis). Universidad Nacional de Colombia, Medellín.

García, V. H., Reiners, P. W., Shuster, D. L., Idleman, B. D., \& Zeitler, P. K. (2018). Thermochronology of sandstone-hosted secondary Fe- and Mn-oxides near Moab, Utah: Record of paleo-fluid flow along a fault. GSA Bulletin, 130(1-2), 93113. https://doi.org/10.1130/B31627.1 
Giraldo, S. J., Trouw, R. A. J., Duffles, P., Vinagre, R., Mejía, M. I., \& Marimon, R. S. (2019). Structural analysis combined with new geothermobarometric and geochronological results of the Além Paraíba shear zone, between Três Rios and Bananal, Ribeira Orogen, SE Brazil. Journal of South American Earth Sciences, 90, 118-136. https://doi.org/10.1016/j. jsames.2018.11.018

Goodfellow, B. W., Viola, G., Bingen, B., Nuriel, P., \& Kylander Clark, A. R. (2017). Paleocene faulting in SE Sweden from U-Pb dating of slickenfibre calcite, Terra Nova, 29(5), 321328, 2017. https://doi.org/10.1111/ter.12280

Gorynski, K. E., Walker, J. D., Stockli, D. F., \& Sabin, A. (2014). Apatite (U-Th)/He thermochronometry as an innovative geothermal exploration tool: A case study from the southern Wassuk range, Nevada. Journal of Volcanology and Geothermal Research, 270, 99-114. https://doi.org/10.1016/j. jvolgeores.2013.11.018

Goswami, S., Mamtani, M. A., \& Rana, V. (2018). Quartz CPO and kinematic analysis in deformed rocks devoid of visible stretching lineations: An integrated AMS and EBSD investigation. Journal of Structural Geology, 115, 270-283. https://doi.org/10.1016/j.jsg.2018.04.008

Grauch, V., \& Hudson, M. R. (2007). Guides to understanding the aeromagnetic expression of faults in sedimentary basins: Lessons learned from the central Rio Grande rift, New Mexico. Geophere, 3(6), 596-623. https://doi.org/10.1130/ GES00128.1

Grégoire, V., Nédélec, A., Monié, P., Montel, J.-M., Ganne, J., \& Ralison, B. (2009). Structural reworking and heat transfer related to the late-Panafrican Angavo shear zone of Madagascar. Tectonophysics, 477(3-4), 197-216. https:/doi. org/10.1016/j.tecto.2009.03.009

Grocott, J., \& Taylor, G. K. (2002). Magmatic arc fault systems, deformation partitioning and emplacement of granitic complexes in the Coastal Cordillera, north Chilean Andes ( $25^{\circ} 30^{\prime}$ S to $27^{\circ} 00^{\prime}$ S). Journal of the Geological Society, 159(4), 425-442. https://doi.org/10.1144/0016-764901-124

Grujic, D., Stipp, M., \& Wooden, J. L. (2011). Thermometry of quartz mylonites: Importance of dynamic recrystallization on Ti-in-quartz reequilibration. Geochemistry, Geophysics, Geosystems, 12(6), Q06012. https://doi. org/10.1029/2010GC003368

Grün, R. (1989). Electron spin resonance (ESR) dating. Quaternary International, 1, 65-109. https://doi.org/10.1016/10406182(89)90010-4
Gudmundsson, A., Simmenes, T. H., Larsen, B., \& Philipp, S. L. (2010). Effects of internal structure and local stresses on fracture propagation, deflection, and arrest in Fault zones. Journal Structural Geology, 32(11), 1643-1655. https://doi. org/10.1016/j.jsg.2009.08.013

Gumbsch, P. (2001). Modelling brittle and semi-brittle fracture processes. Materials Science and Engineering, A(319-321), 1-7. https://doi.org/10.1016/S0921-5093(01)01062-0

Gunn, P., Maidment D., \& Milligan. P. (1997). Interpreting aeromagnetic data in areas of limited outcrop. AGSO Journal of Australian Geology and Geophysics, 17(2), 175-186.

Hadizadeh, J., \& Tullis, J. (1992). Cataclastic flow and semi-brittle deformation of anorthosite. Journal of Structural Geology, 14(1), 57-63. https://doi.org/10.1016/0191-8141(92)

Haines, S., \& van der Pluijm, B. (2008). Clay quantification and Ar-Ar dating of synthetic and natural gouge: Application to the Miocene Sierra Mazatán detachment fault, Sonora, Mexico. Journal of Structural Geology, 30(4), 525-538. https://doi.org/10.1016/j.jsg.2007.11.012

Haines, S. H., Kaproth, B., Marone, C., Saffer, D., \& van der Pluijm, B. (2013). Shear zones in clay-rich fault gouge: A laboratory study of fabric development and evolution. Journal of Structural Geology, 51, 206-225. https://doi. org/10.1016/j.jsg.2013.01.002

Hammarstrom, J. M., \& Zen, E. A. (1986). Aluminum in hornblende: An empirical geobarometer. American Mineralogist, 71(11-12), 1297-1313.

Hames, W. E., \& Bowring, S. A. (1994). An empirical evaluation of the Ar diffusion geometry in muscovite. Earth and Planetary Science Letters, 124(1-4), 161-167. https://doi. org/10.1016/0012-821X(94)00079-4

Hancock, P. L. (1985). Brittle microtectonics Principles and practice. Journal of Structural Geology, 7(3-4), 437-457. https://doi.org/10.1016/0191-8141(85)90048-3

Hanmer, S. (1988). Great Slave Lake shear zone, Canadian Shield: Reconstructed vertical profile of a crustal-scale fault zone. Tectonophysics, 149(3-4), 245-264. https://doi. org/10.1016/0040-1951(88)90176-X

Hanmer, S. (1989). Initiation of cataclastic flow in a mylonite zone. Journal of Structural Geology, 11(6), 751-762. https:// doi.org/10.1016/0191-8141(89)90009-6

Hardcastle, K. C. (1989). Possible paleostress tensor configurations derived from fault-slip data in eastern Vermont and western New Hampshire. Tectonics, 8(2), 265-284. https:// doi.org/10.1029/TC008i002p0026 
Harley, S. L., Kelly, N. M., \& Möller, A. (2007). Zircon behavior and the thermal histories of mountain chains. Elements, 3(1), 25-30. https://doi.org/10.2113/gselements.3.1.25

Harlov, D. (2015). Fluids and geochronometers: Charting and dating mass transfer during metasomatism and metamorphism. Journal of Indian Institute of Science, 95(2), 109-123.

Harrison, T. M., Célérier, J., Aikman, A. B., Hermann, J., \& Heizler, M. T. (2009). Diffusion of ${ }^{40} \mathrm{Ar}$ in muscovite. Geochimica et Cosmochimica Acta, 73(4), 1039-1051. https:// doi.org/10.1016/j.gca.2008.09.038

Hatcher, R. D. (1995). Structural Geology: Principles, concepts, and problems. Prentice Hall.

Hausegger, S., \& Kurz, W. (2013). Cataclastic faults along the SEMP fault system (Eastern Alps, Austria): A contribution to fault zone evolution, internal structure and paleo-stresses. Tectonophysics, 608, 237-251. https://doi.org/10.1016/j. tecto.2013.09.032

Heineke, C., Hetzel, R., Nilius, N. P., Zwingmann, H., Todd, A., Mulch, A., Wölfler, A., Glotzbach, C., Akal, C., \& Dunkl, I. (2019). Detachment faulting in a divergent core complex constrained by fault gouge dating and low-temperature thermochronology. Journal of Structural Geology, 127, 103865. https://doi.org/10.1016/j.jsg.2019.103865

Hickey, K. A., Barker, S. L. L., Dipple, G. M., Arehart, G. B., \& Donelick, R. A. (2014). The brevity of hydrothermal fluid flow revealed by thermal halos around giant gold deposits: Implications for Carlin-type gold systems. Economic Geology, 109(5), 1461-1487. https://doi.org/10.2113/econgeo.109.5.1461

Higgins, M. W. (1971). Cataclastic rocks. Geological Survey Professional Paper, 687. United States Government Printing Office. Library of Congress catalog-card No. 71611932. Washington.

Hills, S. (1972). Elements of structural geology. Chapman and Hall Ltd. https://doi.org/10.1007/978-94-009-5843-2

Hippertt, J., Lana, C., \& Takeshita, T. (2001). Deformation partitioning during folding of banded iron formation. Journal of Structural Geology, 23(5), 819-834. https://doi. org/10.1016/S0191-8141(00)00128-0

Hippertt, J., Rocha, A., Lana, C., Egydio Silva, M., \& Takeshita, T. (2001). Quartz plastic segregation and ribbon development in high-grade stripped gneisses. Journal of Structural Geology, 23(1), 67-80. https://doi.org/10.1016/S01918141(00)00129-2
Hippertt, J. F., \& Massucatto, A. J. (1998). Phyllonitization and development of kilometer-size extension gashes in a continental-scale strike-slip shear zone, north Goiás, central Brazil. Journal of Structural Geology, 20(4), 433-445. https://doi.org/10.1016/S0191-8141(97)00106-5

Hnat, J. S., \& van der Pluijm, B. A. (2014). Fault gouge dating in the Southern Appalachians, USA. GSA Bulletin, 126(5-6), 639-651. https://doi.org/10.1130/B30905.1

Hodgson, C. J. (1989). The structure of shear-related, vein-type gold deposits: A review. Ore Geology Reviews, 4(3), 231273. https://doi.org/10.1016/0169-1368(89)90019-X

Hooper, R. J., \& Hatcher, R. D. (1988). Mylonite from the Towaliga fault zone, central Georgia: Products of heterogeneous non-coaxial deformation. Tectonophysics, 152(1-2), 1-17. https://doi.org/10.1016/0040-1951(88)90026-1

Hopgood, A. M. (1999). Determination of structural successions in migmatites and gneisses. Springer Science + Busines Media, B. V. https://doi.org/10.1007/978-94-011-4427-8

Höeppener, R. (1955). Tektonik im Schiefergebirge. Geologische Rundschau, 44, 26-58. https://doi.org/10.1007/BF01802903

Hueck, M., Wemmer, K., Basei, M. A. S., Philipp, R. P., Oriolo, S., Heidelbach, F., Oyhantçabal, P., \& Siegesmund, S. (2020). Dating recurrent shear zone activity and the transition from ductile to brittle deformation: White mica geochronology applied to the Neoproterozoic Dom Feliciano Belt in Sourh Brazil. Journal of Structural Geology, 141, 104-199. https://doi.org/10.1016/j.jsg.2020.104199

Hurford, A. J. (1986). Cooling and uplift patterns in the Lepontine Alps, South Central Switzerland and an age of vertical movement on the Insubric fault line. Contributions to Mineralogy and Petrology, 92, 413-427. https://doi.org/10.1007/ BF00374424

Iacopini, D., Passchier, C. W., Koehn, D., \& Carosi, R. (2007). Fabric attractors in general triclinic flow systems and their application to high strain shear zones: A dynamical system approach. Journal of Structural Geology, 29(2), 298-317. https://doi.org/10.1016/j.jsg.2006.10.002

Ikeya, M. (ed.). (1993). New applications of electron spin resonance. World Scientific. https://doi.org/10.1142/1854

Ikeya, M., Miki, T., \& Tanaka, K. (1982). Dating of a fault by electron spin resonance on intrafault materials. Science, 215(4538), 1392-1393. https://doi.org/10.1126/science.215.4538.1392

Jefferies, S. P., Holdsworth, R. E., Wibberley, C. A. J., Shimamoto, T., Spiers, C. J., Niemeijer, A. R., \& Lloyd, G. E. (2006). 
The nature and importance of phyllonite development in crustal-scale fault cores: an example form the Median Tectonic Line, Japan. Journal of Structural Geology, 28(2), 220235. https://doi.org/10.1016/j.jsg.2005.10.008

Jelinek, V. (1981). Characterization of the magnetic fabric of rocks. Tectonophysics, 79(3-4), 63-67. https://doi. org/10.1016/0040-1951(81)90110-4

Jenkin, G. R. T. (1997). Mode effects on cooling rate estimates from Rb-Sr data. Geology, 25, 907-910.

Jenkin, G. R. T., Ellam, R. M., Rogers, G., \& Stuart, F. M. (2001). An investigation of closure temperature of the biotite RbSr system: The importance of cation exchange. Geochimica et Cosmochimica Acta, 65(7), 1141-1160. https://doi. org/10.1016/S0016-7037(00)00560-3

Jiang, D., \& White, J. C. (1995). Kinematic of rock flow and the interpretation of geological structures, with particular reference to shear zones. Journal of Structural Gelogy, 17(9), 1249-1265. https://doi.org/10.1016/0191-8141(95)00026-A

Jiang, Y., Zhao, K., Imber, J., Chen, L., \& Hu, H. (2020). Recognizing the internal structure of normal faults in clastic rocks and its impact on hydrocarbon migration: A case study from Nanpu Depression in the Bohai Bay Basin, China. Journal of Petroleum Science and Engineering, 184, 106492. https://doi.org/10.1016/j.petrol.2019.106492

Johansen, S. E., \& Fossen, H. (2008). Internal geometry of fault damage zones in interbedded siliciclastic sediments. In W. Kurz, C. A. J. Wibberley, J. Imber, C. Collettini, \& R. E. Holdsworth (eds), The Internal Structure of Fault Zones: Implications for Mechanical and Fluid-Flow Properties (pp. 35-56), Special Publications vol. 299. Geological Society of London. https://doi.org/10.1144/SP299.3

Johnson, S. E., Lenferink, H. J., Price, N. A., Marsh, J. H., Koons, P. O., West Jr., D. P., \& Beane, R. (2009). Clast-based kinematic vorticity gauges: The effects of slip at matrix/ clast interfaces. Journal of Structural Geology, 31(11), 13221339. https://doi.org/10.1016/j.jsg.2009.07.008

Kadima, E., Delvaux, D., Sebagenzi, S., Tack, L., \& Kabeya, S. (2011). Structure and geological history of the Congo Basin: An integrated interpretation of gravity, magnetic and reflection seismic data. Basin Research, 23(5), 499-527. https://doi.org/10.1111/j.1365-2117.2011.00500.x

Keller, E. A., \& Pinter, N. (2002). Active tectonics, earthquakes, uplift and landscape (2nd ed.), Prentice Hall, Upper Saddle River.
Kelley, S. (2002). K-Ar and Ar-Ar Dating. Reviews in Mineralogy and Geochemistry, 47(1), 785-818. https://doi. org/10.2138/rmg.2002.47.17

Ketcham, R. A., Donelick, R. A., \& Carlson, W. D. (1999). Variability of apatite fission-track annealing kinetics. III: Extrapolation to geological time scales. American Mineralogist, 84(9), 1235-1255. https://doi.org/https://doi. org/10.2138/am-1999-0903

Kilian, R., Heilbronner, R., \& Stünitz, H. (2011). Quartz grain size reduction in a granitoid rock and the transition from dislocation to diffusion creep. Journal of Structural Geology, 33(8), 1265-1284. https://doi.org/10.1016/j.jsg.2011.05.004

Killick, A. M. (2003). Fault rock classification: An aid to structural interpretation in mine and exploration geology. South African Journal of Geology, 106(4), 394-402. https://doi. org/10.2113/106.4.395

Kim, Y. S., Peacock, D. C. P., \& Sanderson, D. J. (2003). Mesoscale strike-slip faults and damage zones at Marsalforn, Gozo Island, Malta. Journal of Structural Geology, 25(5), 793-812. https://doi.org/10.1016/S0191-8141(02)00200-6

Kirkland, C. L., Fougerouse, D., Reddy, S. M., Hollis, J., \& Saxey, D. W. (2018a). Assessing the mechanisms of common $\mathrm{Pb}$ incorporation into titanite. Chemical Geology, 483, 558566. https://doi.org/10.1016/j.chemgeo.2018.03.026

Kirkland, C. L., Yakymchuk, C., Szilas, K., Evans, N., Hollis, J., McDonald, B., \& Gardiner, N. J. (2018b). Apatite: A U-Pb thermochronometer or geochronometer? Lithos, 318-319, 143-157. https://doi.org/10.1016/j.lithos.2018.08.007

Kirkpatrick, J. D., \& Rowe, C. D. (2013). Disappearing ink: How pseudotachylytes are lost from the rock record. Journal of Structural Geology, 52, 183-198. https://doi.org/10.1016/j. jsg.2013.03.003

Kjenes, M. (2018). The geometry and evolution of deformation bands in volcaniclastic rocks: Insights from Eastern Tawan (Master thesis). Departamento de Ciencias de la Tierra. Universidad de Bergen.

Kligfield, R., Hunziker, J., Dallmeyer, R. D., \& Schamel, S. (1986). Dating of deformation phases using K-Ar and Ar/Ar techniques: Results from the Northern Apennines. Journal of Structural Geology, 8(7), 791-798. https:/doi. org/10.1016/0191-8141(86)90025-8

Knipe, R. J. (1989). Deformation mechanisms: Recognition from natural tectonites. Journal of Structural Geology, 11(12), 127-146. https://doi.org/10.1016/0191-8141(89)90039-4 
Kumerics, C., Ring, U., Brichau, S., Glodny, J., \& Monié, P. (2005). The extensional Messaria shear zone and associated brittle detachment faults, Aegean Sea, Greece. Journal of the Geological Society, 162(4), 701-721. https://doi. org/10.1144/0016-764904-041

Lacombe, O. (2012). Do fault slip data inversions actually yield "paleostresses" that can be compared with contemporary stresses? A critical discussion. Compter Rendus Geoscience, 344(3-4), 159-173. https://doi.org/10.1016/j. crte.2012.01.006

Lagroix, F., \& Borradaile, G. J. (2000). Magnetic fabric interpretation complicated by inclusions in mafic silicates. Tectonophysics, 325(3-4), 207-255. https://doi.org/10.1016/ S0040-1951(00)00125-6

Langille, L., Jessup, M. J., Cottle, J. M., Newell, D., \& Seward, G. (2010). Kinematic evolution of the Ama Drime detachment: Insights into orogen-parallel extension and exhumation of the Ama Drime Massif, Tibet-Nepal. Journal of Structural Geology, 32(7), 900-919. https://doi.org/10.1016/j. jsg.2010.04.005

Laslett, G. M., Green, P. F., Duddy, I. R., \& Gleadow, A. J. W. (1987). Thermal annealing of fission tracks in apatite. 2. A quantitative analysis. Chemical Geology, 65(1), 1-13. https://doi.org/10.1016/0168-9622(87)90057-1

Launeau, P., \& Cruden A. R. (1998). Magmatic fabric acquisition mechanisms in a syenite: Results of a combined anisotropy of magnetic susceptibility and image analysis study. Journal of Geophysical Research, 103(B3), 5067-5089. https://doi.org/10.1029/97JB02670

Launeau, P., \& Robin, P. Y. (2005). Determination of fabric and strain ellipsoids from measured sectional ellipses: Implementations and applications. Journal of Structural Geology, 27(12), 2223-2233. https://doi.org/10.1016/j. jsg.2005.08.003

Law, R. D. (1990). Crystallographic fabrics: a selective review of their applications to research in structural geology. In R. J. Knipe, \& E. H. Rutter (eds.), Deformation mechanisms, rheology and tectonics (pp. 335-352). Special Publication vol. 54. Geological Society of London. https://doi.org/10.1144/ GSL.SP.1990.054.01.30

Law, R. D. (2010). Moine thrust zone mylonites at the Stack of Glencoul: II e results of vorticity analyses and their tectonic significance. In R. D. Law, R. W. H. Butler, R. E. Holdsworth, M. Krabbendam, \& R. A. Strachan (eds.), Continental tectonics and mountain building: The Legacy of Peach and Horne (pp. 579-602). Special Publications vol. 335. Geological Society of London.

Lawley, C. J. M., Selby, D., \& Imber, J. (2013). Re-Os molybdenite, pyrite, and chalcopyrite geochronology, Lupa Goldfield, Southwestern Tanzania: Tracing metallogenic time scales at midcrustal shear zones hosting orogenic Au deposits. Economic Geology, 108(7), 1591-1613. https://doi. org/10.2113/econgeo.108.7.1591

Lee, H. K., \& Schwarcz, H. P. (1994). ESR plateau dating of fault gouge. Quaternary Science Reviews, 13(5-7), 629-634. https://doi.org/10.1016/0277-3791(94)90090-6

Lee, H. K., \& Yang, J. S. (2007). ESR dating of the Eupchon fault, South Korea. Quaternary Geochronology, 2(1-4), 392397. https://doi.org/10.1016/j.quageo.2006.04.009

Lee, J. K. W., Williams, I. S., \& Ellis, D. J. (1997). Pb, U and Th diffusion in natural zircon. Nature, 390(6656), 159-162. https://doi.org/10.1038/36554

Lin, A. (1999a). S-C cataclasite in granitic rock. Tectonophysics, 304(3), 257-273. https://doi.org/10.1016/S00401951(99)00026-8

Lin, A. (1999b). Roundness of clast in pseudotachylytes and cataclastic rocks as an indicator of frictional melting. Journal of Structural Geology, 21(5), 473-478. https://doi. org/10.1016/S0191-8141(99)00030-9

Lin, A. (2008). Fossil earthquakes: The formation and preservation of pseudotachylytes. Lecture notes in Earth Sciences. Springer. Springer-Verlag.

Lin, A., \& Yamashita, K. (2013). Spatial variations in damage zone width along strike-slip faults: An example from active faults in southwest Japan. Journal of Structural Geology, 57, 1-15. https://doi.org/10.1016/j.jsg.2013.10.006

Lindanger, M., Gabrielsen, R. H., \& Braathen, A. (2007). Analysis of rock lenses in extensional faults. NorwegianzJournal Geology, 87(4), 361-372.

Lister, G. S., \& Hobbs, B. E. (1980). The simulation of fabric development during plastic deformation and its application to quartzite: the influence of deformation history. Journal of Structural Geology, 2(3), 355-370. https://doi.org/ 10.1016/0191-8141(80)90023-1

Lister, G. S., \& Snoke, A. W. (1984). S-C mylonites. Journal of Structural Geology, 6(6), 616-638. https://doi.org/ 10.1016/0191-8141(84)90001-4

Lister, G. S., \& Williams, P. F. (1983). The partitioning of deformation in flowing rock masses. Tectonophysics, 92(1-3), 1-33. https://doi.org/10.1016/0040-1951(83)90083-5 
Löbens, S., Bense, F. A., Wemmer, K., Dunkl, I., Costa, C. H., Layer, P., \& Siegesmund, S. (2011). Exhumation and uplift of the Sierras Pampeanas: Preliminary implications from K-Ar fault gouge dating and low-T thermochronology in the Sierra de Comechingones (Argentina). International Journal of Earth Science, 100, 671-694. https://doi. org/10.1007/s00531-010-0608-0

López-Isaza, J. A., Cuéllar Cárdenas, M. A., Osorio N., J. A. N., Bernal V., L. E. V., \& Cortés, E. C. (2008). Pseudotaquilitas y el carácter paleosísmico de un segmento del Sistema de Fallas de Bucaramanga (SFB), noreste del municipio Pailitas, departamento del Cesar, Colombia. Boletín de Geología, 30(2), 79-92.

López-Isaza, J. A., Cuéllar-Cárdenas, M. A., Cetina Tarazona, L. A. T., Forero-Ortega, A. J., Suárez Arias, A. M., Muñoz Rodríguez, O. F., Aguirre, L. M., \& Gutiérrez López, M. J. (2020). Representación gráfica de datos estructurales en campo: Una propuesta metodológica para su aplicación en terrenos deformados. Informe interno. Servicio Geológico Colombiano.

Louis, S., Luijendijk, E., Dunkl, I., \& Person, M. (2019). Episodic fluid flow in an active fault. Geology, 47(10), 938-942. https://doi.org/10.1130/G46254.1

MacNamee, A., \& Stockli, D. F. (2015). Constraining age and locations of active and paleofluid flow systems in Dixie Valley, Nevada, with Apatite (U-Th)/He thermochronometry, AGU fall meeting abstracts, San Francisco, CA, December 2015, Abstract V51H-06.

Magloughlin, J. F. (2010). Discussion of "Classification of fault breccias and related fault rocks", by Woodcock \& Mort: The particular problem of pseudotachylyte. Geological Magazine, 147(6), 971-973. https://doi.org/10.1017/ S0016756810000166

Magloughlin, J. F., Hall, C. M., \& van der Pluijm, B. A. (2001). ${ }^{40} \mathrm{Ar}-{ }^{39} \mathrm{Ar}$ geochronometry of pseydotachylytes by vacuum encapsulation: North Cascade Mountains, Washington, USA. Geology, 29(1), 51-54. https://doi.org/10.1130/00917613(2001)029<0051:AAGOPB > 2.0.CO;2

Maitland, T., \& Sitzman, S. (2007). Electron backscatter diffraction (EBSD) technique and materials characterization examples. In W. Zhou, \& Z. L. Wang, Scanning microscopy for nanotechnology: Techniques and applications (pp. 4175). Springer.

Mallast, U., Gloaguen, R., Geyer, S., Rödiger, T., \& Siebert, C. (2011). Derivation of groundwater flow-paths based on semi-automatic extraction of lineaments from remote sensing data. Hydrology and Earth System Sciences, 15(1), 2665-2678. https://doi.org/10.5194/hessd-8-1399-2011

Marchionni, D. S., \& Cavayas, F. (2014). La teledetección por radar como fuente de información litológica y estructural. Análisis espacial de imágenes SAR de RADARSAT-1. Geoacta, 39(1), 62-89.

Mariani, E., Prior, D. J., McNamara, D., Pearce, M. A., Seaton, N., Seward, G., Tatham, D., \& Wheeler, J. (2008). Electron backscatter diffraction (EBSD) in the SEM: Applications to microstructures in minerals and rocks and recent technological advancements. Seminarios de la Sociedad Española de Mineralogía (5), 7-19.

Marrett, R., \& Allmendinger, R. W. (1990). Kinematic analysis of fault-slip data: Journal of Structural Geology, 12(8), 973986. https://doi.org/10.1016/0191-8141(90)90093-E

Marshak, S., \& Mitra, G. (1988). Basic methods of structural geology. Prentice Hall.

McCalpin, J. P. (2009). Paleoseismology (2nd ed.). International Geophysics Series, vol. 95. Elsevier.

McClay, K. (1987). The mapping of geological structures. John Wiley and Sons.

McDermott, R. G., Ault, A. K., Evans, J. P., \& Reiners, P. W. (2017). Thermochronometric and mirrors, Wasatch fault zone, UT, USA. Earth and Planetary Science Letters, 471, 85-93. https://doi.org/10.1016/j.epsl.2017.04.020

McGrath, A. G., \& Davison, I. (1995). Damage zone geometry around fault tips. Journal of Structural Geology, 17(7), 10111024. https://doi.org/10.1016/0191-8141(94)00116-H

McKenzie, D. (1979). Finite deformation during fluid flow. Geophysical Journal of the Royal Astronomical Society, 58(3), 689-715. https://doi.org/10.1111/j.1365-246X.1979. tb04803.x

McWilliams, C. K., Wintsch, R. P., \& Kunk, M. J. (2007). Scales of equilibrium and disequilibrium during cleavage formation in chlorite and biotite-grade phyllites, SE Vermont. Journal of Metamorphic Geology, 25(8), 895-913. https:// doi.org/10.1111/j.1525-1314.2007.00734.x

Means, W. D., Hobbs, B. E., Lister, G. S., \& Williams, P. F. (1980). Vorticity and non-coaxiality in progressive deformations. Journal of Structural Geology, 2(3), 371-378. https://doi.org/10.1016/0191-8141(80)90024-3

Mejía, E. L., Velandia, F., Zuluaga, C. A., López, J. A., \& Cramer, T. (2012). Análisis estructural al noreste del volcán Nevado del Ruiz, Colombia: Aporte a la exploración geotérmica. Boletín de Geología, 14(1), 27-21. 
Mendivelso, D. L. (2008). Curso de fotogeología, geomorfología y aplicaciones de la percepción remota: Metodología para los levantamientos fotogeológicos. http://recordcenter.sgc.gov.co/B12/23008002524448/documento/ pdf/2105244481103000.PDF

Micklethwaite, S., Sheldon, H. A., \& Baker, T. (2010). Active fault and shear processes and their implications for mineral deposit formation and discovery. Journal of Structural Geology, 32(2), 151-165. https://doi.org/10.1016/j. jsg.2009.10.009

Miller, H. B. D., Vasconcelos, P. M., Eiler, J. M., \& Farley, K. A. (2017). A Cenozoic terrestrial paleoclimate record from He dating and stable isotope geochemistry of goethite from Western Australia. Geology, 45(10), 895-898. https:// doi.org/10.1130/G38989.1

Miranda, T. S., Neves, S. P., Celestino, M. A. L., \& Roberts, N. M. W. (2020). Structural evolution of the Cruzeiro do Nordeste shear zone (NE Brazil): Brasiliano-Pan-Africanductile-to-brittle transition and Cretaceous brittle reactivation. Journal of Structural Geology, 141, 104203. https:// doi.org/10.1016/j.jsg.2020.104203

Mitchell, T. M., \& Faulkner, D. R. (2009). The nature and origin of off-fault damage surrounding strike-slip fault zones with a wide range of displacements: a field study from the Atacama fault system, northern Chile. Journal of Structural Geology, 31(8), 802-816. https://doi.org/10.1016/j. jsg.2009.05.002

Moazzen, M., \& Drop, G. T. R. (2005). Application of mineral thermometers and barometers to granitoid igneous rocks: The Etive Complex, W Scotland. Mineralogy and Petrology, 83(1), 27-53. https://doi.org/10.1007/s00710-004-0059-z

Moecher, D. P., \& Brearley, A. J. (2004). Mineralogy and petrology of a mullite-bearing pseudotachylyte: Constraints on the temperature of coseismic frictional fusion. American Mineralogist, 89(10), 1486-1495. https://doi.org/10.2138/ am-2004-1017

Monteiro, H., Vasconcelos, P. M., Farley, K. A., Spier, C. A., \& Mello, C. L. (2014). (U-Th)/He geochronology of goethtite and the origin and evolution of cangas. Geochimica et Cosmochimica Acta, 131, 267-289. https://doi.org/10.1016/j. gca.2014.01.036

Moreira, N., \& Dias, R. (2018). Domino structures evolution in strike-slip shear zones: The importance of the cataclastic flow. Journal of Structural Geology, 110, 187-201. https:// doi.org/10.1016/j.jsg.2018.01.010
Moser, A. C., Evans, J. P., Ault, A. K., Janecke, S. U., \& Bradbury, K. K. (2017). (U-Th)/He thermochronometry reveals Pleistocene punctuated deformation and synkinematic hematite minarlization in the Mecca Hills, southernmost San Andreas Fault zone. Earth and Planetary Science Letters, 476, 87-99. https://doi.org/10.1016/j.epsl.2017.07.039

Mottram, C., Grujic, D., \& Coutand, I. (2018). Using U-Pb calcite dating to directly-date continental-scale faults. Geophysical Research Abstracts, 20, EGU2018-14685.

Mukherjee, S. (2014). Atlas of shear zone structures in Meso-scale. Springer Science and Business Media.

Mulch, A., \& Cosca, M. A. (2004). Recrystallization or cooling ages: In situ UV-laser ${ }^{40} \mathrm{Ar} /{ }^{39} \mathrm{Ar}$ geochronology of muscovite in mylonitic rocks. Journal of Geological Society, 161(4), 573-582. https://doi.org/10.1144/0016-764903-110

Mulch, A., Cosca, M. A., \& Handy, M. R. (2002). In-situ UV-laser ${ }^{40} \mathrm{Ar} /{ }^{39} \mathrm{Ar}$ geochronology of a micaceous mylonite: An example of defect-enhanced argon loss. Contributions to Mineralogy and Petrology, 142, 738-752. https://doi. org/10.1007/s00410-001-0325-6

Müller, W., Mancktelow, N. S., \& Meier, M. (2000). Rb-Sr microchrons of synkinematic mica in mylonites: An example from the DAV fault of the Eastern Alps. Earth and Planetary Science Letter, 180(3-4), 385-397. https://doi.org/10.1016/ S0012-821X(00)00167-9

Nakamura, N., \& Borradaile, G. (2004). Metamorphic control of magnetic susceptibility and magnetic fabrics: a 3-D projection. In F. Martín Hernández, C. M. Luneburg, C. Aubourg, \& M. Jackson (eds.), Magnetic fabric: methods and applications - an introduction. Special Publications vol. 238. Geological Society of London. https://doi.org/10.1144/ GSL.SP.2004.238.01.01

Nicchio, M. A., Nogueira, F. C. C., Balsamo, F., Souza, J. A. B., Carvalho, B. R. B. M., \& Bezerra, F. H. R. (2018). Development of cataclastic foliation in deformation bands in feldspar-rich conglomerates of the Rio do Peixe Basin, NE Brazil. Journal of Structural Geology, 107, 132-141. https:// doi.org/10.1016/j.jsg.2017.12.013

Nuriel, P., Miller, D. M., Schmidt, K. M., Coble, M. A., \& Maher, K. (2019). Ten-million years of activity within the Eastern California shear zone from $\mathrm{U}-\mathrm{Pb}$ dating of fault-zone opal. Earth and Planetary Science Letters, 521, 37-45. https://doi. org/10.1016/j.epsl.2019.05.047

Nuriel, P., Rosenbaum, G., Uysal, T. I., Zhao, J., Golding, S. D., Weinberger, R., Karabacak, V., \& Avni, Y. (2011). For- 
mation of fault-related calcite precipitates and their implications for dating fault activity in the East Anatolian and Dead Sea fault zones. In A. Fagereng, V. G. Toy, \& J. V. Rowland (eds.), Geology of the earthquake source: A volume in honour of Rick Sibson (pp. 229-248). Special Publications vol. 359. Geological Society of London. https://doi. org/10.1144/SP359.13

Nuriel, P., Weinberger, R., Kylander Clark, A. R. C., Hacker, B. R., \& Craddock, J. P. (2017). The onset of the Dead Sea transform based on calcite age-strain analyses. Geology, 45(7), 587-590. https://doi.org/10.1130/G38903.1

Ohtani, T., Shigematsu, N., Fujimoto, K., Tomita, T., \& Iwano, H. (2004). Grochronological constraint on the brittle-plastic deformation along the Hatagawa fault zone, NE Japan. Earth Planets Space, 56(Suppl. 12), 1201-1027. https://doi. org/10.1186/BF03353341

Oliot, E., Gonçalves, P., Schulmann, K., Marquer, D., \& Lexa, O. (2014). Mid-crustal shear zone formation in granitic rocks: Constraints from quantitative textural and crystallographic preferred orientations analyses. Tectonophysics, 612-613, 63-80. https://doi.org/10.1016/j.tecto.2013.11.032

Oriolo, S., Oyhantçabal, P., Heidelbach, F., Wemmer, K., \& Siegesmund, S. (2015). Structural evolution of the Sarandí del Yí shear zone: Kinematics, deformation conditions and tectonic significance. International Journal Earth Science, 104(7), 1759-1777. https://doi.org/10.1007/s00531-0151166-2

Oriolo, S., Oyhantçabal, P., Wemmer, K., Basei, M. A. S., Benowitz, J., Pfänder, J., Hannich, F., \& Siegesmund, S. (2016a). Timing of deformation in the Sarandí del Yí shear zone, Uruguay: Implications for the amalgamation of Western Gondwana during the Neoproterozoic Brasiliano-Pan-African Orogeny. Tectonics, 35(3), 754-771. https://doi. org/10.1002/2015TC004052

Oriolo, S., Oyhantçabal, P., Wemmer, K., Heidelbach, F., Pfänder, J., Basei, M. A. S., Hueck, M., Hannich, F., Sperner, B., \& Siegesmund, S. (2016b). Shear zone evolution and timing of deformation in the Neoproterozoic transpressional Dom Feliciano Belt, Uruguay. Journal Structural Geology, 92, 5978. https://doi.org/10.1016/j.jsg.2016.09.010

Oriolo, S., Wemmer, K., Oyhantçabal, P., Fossen, H., Schulz, B., \& Siegesmund, S. (2018). Geochronology of shear zones: A review. Earth-Science Reviews, 185, 665-683. https://doi. org/10.1016/j.earscirev.2018.07.007
Ortner, H., Reiter, F., \& Acs, P. (2002). Easy handling of tectonic data: The programs TectonicVP for Mac and TectonicsFP for Windows. Computers \& Geosciences, 28(10), 1193-1200. https://doi.org/10.1016/S0098-3004(02)00038-9

Ostermeijer, G. A., Mitchell, T. M., Aben, F. M., Dorsey, M. T., Browning, J., Rockwell, T. K., Fletcher, J. M., \& Ostermeijer, F. (2020). Damage zone heterogeneity on seismogenic faults in crystalline rock; a field study of the Borrego Fault, Baja California. Journal of Structural Geology, 137, 104016. https://doi.org/10.1016/j.jsg.2020.104016

Oyhantçabal, P., Heimann, A., \& Miranda, S. (2001). Measurement and interpretation of strain in the syntectonic Solís de Mataojo Granitic Complex, Uruguay. Journal of Structural Geology, 23(5), 807-817. https://doi.org/10.1016/S01918141(00)00152-8

Oyhantçabal, P., Muzio, R., \& de Souza, S. (1993). Geología y aspectos estructurales del borde orogénico en el extremo sur del cinturón Dom Feliciano. Revista Brasileira de Geociências, 23(3), 296-300. https://doi.org/10.25249/03757536.1993233296300

Oyhantçabal, P., Siegesmund, S., Wemmer, K., \& Layer, P. (2009). The Sierra Ballena shear zone in the southernmost Dom Feliciano Belt (Uruguay): Evolution, kinematics, and deformation conditions. International Journal of Earth Sciences, 99, 1227-1246. https://doi.org/10.1007/s00531-009. 0453-1

Oyhantçabal, P., Wegner Eimer, M., Wemmer, K., Schulz, B., Frei, R., \& Siegesmund, S. (2012). Paleo- and Neoproterozoic magmatic and tectonometamorphic evolution of the Isla Cristalina de Rivera (Nico Pérez Terrane, Uruguay). International Journal of Earth Sciences, 101, 1745-1762. https://doi.org/10.1007/s00531-012-0757-4

Pagel, M., Bonifacie, M., Schneider, D. A., Gautheron, C., Brigaud, B., Calmels, D., Cros, A., Saint-Bezar, B., Landrein, P., \& Sutcliffe, C. (2018). Improving paleohydrological and diagenetic reconstructions in calcite veins and breccia of a sedimentary basin by combining $\Delta 47$ temperature, \$18Owater and U-Pb age. Chemical Geology, 481, 1-17. https://doi.org/10.1016/j.chemgeo.2017.12.026

Paine, D. P., \& Kiser, J. D. (2003). Aerial photography and image interpretation (2nd ed.). Wiley.

Papeschi, S., Musumeci, G., \& Mazzarini, F. (2018). Evolution of shear zones through the brittle-ductile transition: The Calamita Schists (Elba Island, Italy). Journal of Structural Geology, 113, 100-114. https://doi.org/10.1016/j.jsg.2018.05.023 
Park, S., Kim, Y., Ryoo, C., \& Sanderson, D. J. (2010). Fractal analysis of the evolution of a racture network in a granite outcrop, SE Korea. Geosciences Journal, 14, 201-215. https://doi.org/10.1007/s12303-010-0019-z

Parsons, A. J., Ferré, E. C., Law, R. D., Lloyd, G. E., Phillips, R. J., \& Searle, M. P. (2016). Orogen-parallel deformation of the Himalayan midcrust: Insights from structural and magnetic fabric analyses of the Greater Himalayan Sequence, Annapurna-Dhaulagiri Himalaya, central Nepal. Tectonics, 35(11), 2515-2537. https://doi.org/10.1002/2016TC004244

Passchier, C. W. (1997). The fabric attractor. Journal of Structural Geology, 19(1), 113-127. https://doi.org/10.1016/ S0191-8141(96)00077-6

Passchier, C. W., \& Coelho, S. (2006). An outline of shear-sense analysis in high-grade rocks. Gondwana Research, 10(1), 66-76. https://doi.org/10.1016/j.gr.2005.11.016

Passchier, C. W., Myers, J. S., \& Kröner, A. (1990). Field geology of high-grade gneiss terrains. Springer-Verlag. https://doi. org/10.1007/978-3-642-76013-6

Passchier, C. W., \& Trouw, R. A. J. (2005). Microtectonics. Springer Science and Business Media. https://doi. org/10.1007/3-540-29359-0

Paterson, S. R., \& Vernon, R. H. (1995). Bursting the bubble of ballooning plutons: A return to nested diapirs emplaced by multiple processes. GSA Bulletin, 107(11), 1356-1380. https://doi.org/10.1130/0016-7606(1995)107<1356:BTBO $\mathrm{BP}>2.3 . \mathrm{CO} ; 2$

Paterson, S. R., Fowler, T. K. J., Schmidt, K. L., Yoshinobu, A. S., Yuan, E. S., \& Miller, R. B. (1998). Interpreting magmatic fabric patterns in plutons. Lithos, 44(1-2), 53-82. https:// doi.org/10.1016/S0024-4937(98)00022-X

Paterson, S. R., Vernon, R. H., \& Tobisch, O. T. (1989). A review of criteria for the identification of magmatic and tectonic foliations in granitoids. Journal of Structural Geology, 11(3), 349-363. https://doi.org/10.1016/0191-8141(89)90074-6

Pec, M., Stünitz, H., \& Heilbronner, R. (2012). Semi-brittle deformation of granitoid gouges in shear experiments at elevated pressures and temperatures. Journal of Structural Geology, 38, 200-221. https://doi.org/10.1016/j.jsg.2011.09.001

Pennacchioni, G., \& Zucchi, E. (2013). High temperature fracturing and ductile deformation during cooling of a pluton: the Lake Edison granodiorite (Sierra Nevada batholith, California). Journal Structural Geology, 50, 54-81. https:// doi.org/10.1016/j.jsg.2012.06.001
Petit, J. P. (1987). Criteria for the sense of movement on fault surfaces in brittle rocks. Journal of Structural Geology, 9(56), 597-608. https://doi.org/10.1016/0191-8141(87)90145-3

Philpotts, A. R. (1964). Origin of pseudotachylytes. American Journal of Science, 262(8), 1008-1035. https://doi. org/10.2475/ajs.262.8.1008

Picazo, S., Manatschal, G., Cannat, M., \& Andréani, M. (2013). Lithos deformation associated to exhumation of serpentinized mantle rocks in a fossil Ocean Continent transition: The Totalp unit in SE Switzerland. Lithos, 175-176, 255-271. https://doi.org/10.1016/j.lithos.2013.05.010

Platt, J. P. (2015). Rheology of two-phase systems: A microphysi$\mathrm{cal}$ and observational approach. Journal of Structuctural Geolology, 77, 213-227. https://doi.org/10.1016/j.jsg.2015.05.003

Powell, R., \& Holland, T. J. B. (1994). Optimal geothermometry and geobarometry. American Mineralogist, 79(1-2), pp. 120-133.

Powell, R., \& Holland, T. J. B. (2001). Course Notes for "Thermocalc Workshop 2001: Calculating Metamorphic Phase Equilibria”.

Powell, R., \& Holland, T. J. B. (2008). On thermobarometry. Journal of Metamorphic Geology, 26(2), pp. 155-179. https://doi.org/10.1111/j.1525-1314.2007.00756.x

Powell, R., Holland, T. J. B., \& Worley, B. (1998). Calculating phase diagrams involving solid solutions via non-linear equations, with examples using Thermocalc. Journal of Metamorphic Geology, 16(4), 577-588. https://doi. org/10.1111/j.1525-1314.1998.00157.x

Prent, A. M., Beinlich, A., Raimondo, T., Kirkland, C. L., Evans, N. J., \& Putnis, A. (2020). Apatite and monazite: An effective duo to unravel superimposed fluid-flow and deformation events in reactivated shear zones. Lithos, 376-377, 105752. https://doi.org/10.1016/j.lithos.2020.105752

Précigout, J., Prigent, C., Palasse, L., \& Pochon, A. (2017). Water pumping in mantle shear zones. Nature Commununications, 8, 15736. https://doi.org/10.1038/ncomms15736

Prigent, C., Warren, J., Kohli, A., \& Teyssier, C. (2017). The semi-brittle to ductile transition in oceanic faults in peridotite: Mechanisms and P-T conditions. In AGU Fall Meeting 2017, 1-2, Nueva Orleáns.

Prior, D. J., Boyle, A. P., Brenker, F., Cheadle, M.C., Day, A., Lopez, G., Peruzzo, L., Potts, G. J., Reddy, S., Spiess, R., Timms, N. E., Trimby, P., Wheeler, J., \& Zetterstrom, L. (1999). The application of electron backscatter diffraction and orientation contrast imaging in the SEM to textural problems 
in rocks. American Mineralogist, 84(11-12), 1741-1759. https://doi.org/10.2138/am-1999-11-1204

Purdy, J. W., \& Jäger, E. (1976). K-Ar ages on rock-forming minerals from the Central Alps. Memorie degli Istituti di geologia e mineralogia dell'Università di Padova, 30, 3-31.

Qju, D., Liu, Q., Yun, J., Jin, Z., Zhu, D., Li, T., \& Sun, D. (2018). Electron spin resonance (ESR) dating of pre-Quaternary faults in the Sichuan basin, SW China. Journal of Asian Earth Sciences, 163, 142-151. https://doi.org/10.1016/j.jseaes.2018.06.011

Rampal, K. K. (1999). Handbook of aerial photography and interpretation. Concept Publishing Company. https://books. google.com.co/books?id=rmiPV3ABi9EC

Ramsay, J. G., \& Huber, M. I. (1983). The techniques of modern structural geology. Vol. 1: Strain analysis. Academic Press.

Ramsay, J. G. (1980a). The crack-seal mechanism of rock deformation. Nature, 284(5752), 135-139. https://doi.org/ $10.1038 / 284135 \mathrm{a} 0$

Ramsay, J. G. (1980b). Shear zone geometry: A review. Journal of Structural Geology, 2(1-2), 83-99. https://doi.org/ 10.1016/0191-8141(80)90038-3

Ramsay, J. G., \& Huber, M. I. (1987). The techniques of modern structural geology. Vol. 2: Folds and fractures. Academic Press.

Rao, D. P. (2002). Remote sensing application in geomorphology. Tropical Ecology, 43(1), 49-59.

Rasbury, E. T., \& Cole, J. M. (2009). Directly dating geologic events: U-Pb dating of carbonates. Reviews of Geophysics, 47(3), RG3001. https://doi.org/10.1029/2007RG000246

Reavy, R. (1989). Structural controls on metamorphism and syntectonic magmatism: The Portuguese Hercyan collision belt. Journal of the Geological Society, 146(4), 649-657. https://doi.org/10.1144/gsjgs.146.4.0649

Reber, J. E., \& Pec, M. (2018). Comparison of brittle and viscous creep in quartzites: Implications for semi-brittle flow of rocks. Journal of Structural Geology, 113, 90-99. https:// doi.org/10.1016/j.jsg.2018.05.022

Reddy, S., \& Potts, G. (1999). Deformation mechanisms and Ar isotope systematics. In Micas: Implications for absolute deformation ages. Journal of Conference Abstracts, 4(1), 830 p. Cambridge Publications. Cambridge, United Kingdom.

Reddy, S. M., Timms, N. E., Pantleon, W., \& Trimby, P. (2007). Quantitative characterization of plastic deformation of zircon and geological implications. Contributions to Mineralo- gy and Petrology, 153(6), 625-645. https://doi.org/10.1007/ s00410-006-0174-4

Reiners, P. W., \& Brandon, M. T. (2006). Using thermochronology to understand orogenic erosion. Annual Reviews or Earth and Planetary Sciences, 34(1), 419-466. https://doi. org/10.1146/annurev.earth.34.031405.125202

Ribeiro, B. V., Faleiros, F. M., Campanha, G. A. C., Lagoeiro, L., Weinberg, R. F., \& Hunter, N. J. R. (2019). Kinematics, deformational conditions and tectonic setting of the Taxaquara shear zone, a major transpressional zone of the Ribeira Belt (SE Brazil). Tectonophysics, 751, 83-108. https:// doi.org/10.1016/j.tecto.2018.12.025

Ribeiro, B. V., Lagoeiro, L., Faleiros, F. M., Hunter, N. J. R., Queiroga, G., Raveggi, M., Cawood, P. A., Finch, M., \& Campanha, G. A. C. (2020a). Strain localization and fluid-assited deformation in apatite and its influence on trace elements and U-Pb systematics. Earth and Planetary Science Letters, 542, 116421. https://doi.org/10.1016/j.epsl.2020.116421

Ribeiro, B. V., Mulder, J. A., Faleiros, F. M., Kirkland, C. L., Cawood, P. A., O’Sullivan, G., Campanha, G. A. C., Finch, M. A., Weinberg, R. F., \& Nebel, O. (2020b). Using apatite to resolve the age and protoliths of mid-crustal shear zones: A case study from the Taxaquara shear zone, SE Brazil. Lithos, 378-379, 105817. https://doi.org/10.1016/j. lithos.2020.105817

Richard, J., Gratier, J. P., Doan, M. L., Boullier, A. M., \& Renard, F. (2014). Rock and mineral transformations in a fault zone leading to permanent creep: Interactions between brittle and viscous mechanisms in the San Andreas Fault. Journal of Geophysical Research: Solid Earth, 119(11), 8132-8153. https://doi.org/10.1002/2014JB011489

Ricchi, E., Bergemann, C. A., Gnos, E., Berger, A., Rubatto, D., Whitehouse, M. J., \& Walter, F. (2020). Cenozoic deformation in the Tauern Window (Eastern Alps) constrained by in situ Th-Pb dating of fissure monazite. Solid Earth, 11(2), 437-467. https://doi.org/10.5194/se-11-437-2020

Ricchi, E., Gnos, E., Rubatto, D., Whitehouse, M. J., \& Pettke, T. (2020). Ion microprobe dating of fissure monazite in the Western Alps: Insights from the Argentera Massif and the Piemontais and Briançonnais Zones. Swiss Journal of Geosciences, 113(1), 1-27. https://doi.org/10.1186/s00015-020-00365-3

Riedmüller, G., Brosch, F. J., Klima, K., \& Medley, E. W. (2001). Engineering geological characterization of brittle faults and classification of fault rocks. Felsbau, 19(4), 13-19. 
Riley, P. R., Goodwin, L. B., \& Lewis, C. J. (2010). Controls on fault damage zone width, structure, and symmetry in the Bandelier Tuff, New Mexico. Journal of Structural Geology, 32(6), 766-780. https://doi.org/10.1016/j.jsg.2010.05.005

Ring, U., Uysal, I. T., Glodny, J., Cox, S. C., Little, T., Thomson, S. N., Stübner, K., \& Bozkaya, Ö. (2017). Fault-gouge dating in the Southern Alps, New Zealand. Tectonophysics, 717, 321-338. https://doi.org/10.1016/j.tecto.2017.08.007

Roberts, N. M. W. (2019). Mind over methods: Dating deformation with $\mathrm{U}-\mathrm{Pb}$ carbonate geochronology. EGU Blogs, Divisions, Tectonics and Structural Geology. https://blogs. egu.eu/divisions/ts/2019/08/16/minds-over-methods-dating-deformation-with-u-pb-carbonate-geochronology/

Roberts, N. M. W., \& Walker, R. (2016). U-Pb geochronology of calcite-mineralized faults: Absolute timing of rift-related fault events on the northeast Atlantic margin. Geology, 44(7), 531-534. https://doi.org/10.1130/G37868.1

Roberts, N. M. W., Drost, K., Horstwood, M. S. A., Condon, D. J., Chew, D., Drake, H., Milodowski, A. E., McLean, N. M., Smye, A. J., Walker, R. J., Haslam, R., Hodson, K., Imber, J., Beaudoin, N., \& Lee, J. K. (2020a). Laser ablation inductively coupled plasma mass spectrometry (LA-ICP-MS) U-Pb carbonate geochronology: Strategies, progress, and limitations. Geochronology, 2, 33-61. https://doi.org/10.5194/ gchron-2-33-2020

Roberts, N. M. W., Lee, J. K., Holdsworth, R. E., Jeans, C., Farrant, A. R., \& Haslam, R. (2020b). Near-surface Paleocene fluid flow, mineralization and faulting at Flamborough Head, UK: New field observations and U-Pb calcite dating constraints. Solid Earth, 11(5), 1931-1945. https://doi. org/10.5194/se-11-1931-2020

Robin, P. Y. F. (2002). Determination of fabric and strain ellipsoids from measured sectional ellipses-theory. Journal Structural Geology, 24(3), 531-544. https://doi.org/10.1016/ S0191-8141(01)00081-5

Romn-Berdiel, T., Gapais, D., \& Brun, J. P. (1997). Granite intrusion along strike slip zones in experiment and nature. American Journal of Science, 297(6), 651-678. https:/doi. org/10.2475/ajs.297.6.651

Rosenberg, C. L. (2004). Shear zones and magma ascent: A model based on a review of the Tertiary magmatism in the Alps. Tectonics, 23(3), TC3002. https://doi. org/10.1029/2003TC001526

Rutter, E. H., Mecklenburgh, J., \& Brodie, K. H. (2011). Rock mechanics constraints on mid-crustal, low-viscosity flow beneath Tibet. In D. J. Prior, E. H. Rutter, \& D. J. Tatham (eds.), Deformation mechanisms, rheology and tectonics: Microstructures, mechanics and anisotropy (pp. 329-336). Special Publications vol. 360. Geological Society of London. https://doi.org/10.1144/SP360.19

Rutter, E. H. (1986). On the nomenclature of mode of failure transitions in rocks. Tectonophysics, 122(3-4), 381-387. https://doi.org/10.1016/0040-1951(86)90153-8

Sainz, A. C., Peña, I. G., \& Gómez, J. S. (1990). Los métodos de análisis de paleoesfuerzos a partir de poblaciones de fallas: Sistemática y técnicas de aplicación. Estudios Geológicos, 46(5-6), 385-398. https://doi.org/10.3989/ egeol.90465-6469

Sanderson, S., \& Marchini, O. (1984). Transpression. Journal of Structural Geology, 6(5), 449-458. https://doi. org/10.1016/0191-8141(84)90058-0

Santamaría-Díaz, A., Alaniz-Álvarez, S. A., \& Nieto-Samaniego, A. F. (2008). Deformaciones cenozoicas en la cobertura de la falla Caltepec en la región de Tamazulapam, sur de México. Revista Mexicana de Ciencias Geológicas, 25(3), 494-516.

Santos, J. O. S., Hartmann, L. A., Bossi, J., Campal, N., Schipilov, A., Piñeyro, D., \& McNaughton, N. J. (2003). Duration of the Trans-Amazonian cycle and its correlation within South America based on U-Pb Shrimp Geochronology of the La Plata Craton, Uruguay. International Geology Review, 45(3), 27-48. https://doi.org/10.2747/0020-6814.45.1.27

Sarkarinejad, K., Heyhat, M., Faghih, A., \& Kusky, T. (2010). Heterogeneous ductile deformation and quartz c-axis fabric development within the HP-LT Sanandaj-Sirjan Metamorphic Belt, Iran. Tectonophysics, 485(1-4), 283-289. https://doi.org/10.1016/j.tecto.2010.01.006

Sausgruber, T., \& Brandner, R. (2001). The relevance of brittle fault zones in tunnel construction: Lower inn valley feeder line north of the Brenner base tunnel, Tyrol, Austria. Mitt. Österreichische Geologische Gesellschaft, 94, 157-172.

Scheiber, T., Viola, G., Van der Lelij, R., Margreth, A., \& Schönenberger, J. (2019). Microstructurally-constrained versus bulk fault gouge K-Ar dating. Journal of Structural Geology, 127, 103868. https://doi.org/10.1016/j.jsg.2019.103868

Schmidt, M. W. (1992). Amphibole composition in tonalite as a function of pressure: An experimental calibration of the Al-in-hornblende barometer. Contributions to Mineralogy and Petrology, 110(2-3), 304-310. https://doi.org/10.1007/ bf00310745 
Schmid, S. M., \& Casey, M. (1986). Complete fabric analysis of some commonly observed quartz c-axis patterns. In Mineral and Rock Deformation: Laboratory Studies, vol. 36 American Geophysical Union. https://doi.org/10.1029/ GM036p0263

Schmid, S. M., \& Handy, M. R. (1991). Towards a genetic classification of fault rocks: Geological usage and tectonophysical implication. In D. W. Müller, J. A. McKenzie, \& H. Weissert, Controversies in modern geology: Evolution of geological theories in sedimentology, earth history and tectonics. Academic Press.

Schneider, S., Hammerschmidt, K., \& Rosenberg, C. L. (2013). Dating the longevity of shear zones: Insight from ${ }^{40} \mathrm{Ar} /{ }^{39} \mathrm{Ar}$ in situ analysis. Earth and Planetary Science Letters, 369370, 43-58. https://doi.org/10.1016/j.epsl.2013.03.002

Schoene, B. (2014). U-Th-Pb geochronology. In R. L. Rudnick (ed). Treatise on geochemistry: The crust (pp. 341-378). Elsevier, 4 .

Scholz, C. H. (1987). Wear and gouge formation in brittle faulting. Geology, 15(6), 493-495. https://doi.org/10.1130/00917613(1987) 15<493:WAGFIB >2.0.CO

Scholz, C. H. (1988). The brittle-plastic transition and the depth of seismic faulting: Geologische Rundschau, 77(1), 319-328. https://doi.org/10.1007/BF01848693

Scholz, C. H. (2006). The mechanics of Earthquakes and faulting (2nd ed.). Cambridge University Press. https://doi.org/ $10.1017 / 9781316681473$

Selverstone, J., Axen, G. J., \& Luther, A. (2012). Fault localization controlled by fluid infiltration into mylonites: Formation and strength of low-angle normal faults in the midcrustal brittle-plastic transition. Journal of Geophysical Research: Solid Earth, 117(B6), B06210. https://doi. org/10.1029/2012JB009171

Sherlock, S. C., \& Hetzel, R. (2001). A laser-probe ${ }^{40} \mathrm{Ar} /{ }^{39} \mathrm{Ar}$ study of pseudotachylite from the Tambach Fault Zone, Kenya: Direct isotopic dating of brittle faults. Journal Structural Geology, 23(1), 33-44. https://doi.org/10.1016/S01918141(00)00082-1

Sherlock, S. C., Strachan, R. A., \& Jones, K. A. (2009). High spatial resolution ${ }^{40} \mathrm{Ar} /{ }^{39} \mathrm{Ar}$ dating of pseudotachylites: Geochronological evidence for multiple phases of faulting within basement gneisses of the Outer Hebrides (UK). Journal of the Geological Society of London, 166(6), 10491059. https://doi.org/10.1144/0016-76492008-125
Short, H. A., \& Johnson, S. E. (2006). Estimation of vorticity from fibrous calcite veins, central Maine, USA. Journal of Structural Geology, 28(7), 1167-1182. https://doi. org/10.1016/j.jsg.2006.03.024

Shuster, D. L., Vasconcelos, P. M., Heim, J. A., \& Farley, K. A. (2005). Weathering geochronology by (U-Th)/He dating of goethite. Geochimica et Cosmochimica Acta, 69(3), 659673. https://doi.org/10.1016/j.gca.2004.07.028

Sibson, R. H. (1975). Generation of pseudotachylite by ancient seismic faulting. Geophysical Journal International, 43(3), 775-794. https://doi.org/10.1111/j.1365-246X.1975. tb06195.x

Sibson, R. H. (1983). Continental fault structure and the shallow earthquake source. Journal of the Geological Society, 140(5), 741-767. https://doi.org/10.1144/gsjgs.140.5.0741

Sibson, R. H. (1977). Fault rocks and fault mechanisms. Journal of the Geological Society, 133(3), 191-213. https://doi. org/10.1144/gsjgs.133.3.0191

Sibson, R. H. (1979). Fault rocks and structure as indicators of shallow earthquake source processes. U.S. Geological Survey Open-File Report (79), 1239. Proceedings of conference VIII - Analysis of actual fault zones in bedrock.

Sibson, R. H. (1980). Transient discontinuities in ductile shear zones. Journal of Structural Geology, 2(1-2), 165-171. https://doi.org/10.1016/0191-8141(80)90047-4

Sibson, R. H. (1990). Conditions for fault-valve behaviour. In R. J. Knipe, \& E. H. Rutter (eds.), Deformation mechanisms, rheology and tectonics (pp. 15-28). Special Publications vol. 54. Geological Society of London. https://doi.org/10.1144/ GSL.SP.1990.054.01.02

Siegesmund, S., Steenken, A., López, M. G. L., Wemmer, K., Hoffman, A., \& Mosh, S. (2004). The Las Chacras-Potrerillo batholith (Pampean Ranges, Argentina): Structural evidences, emplacement and timing of the intrusion. International Journal Earth Science, 93(1), 23-43. https://doi. org/10.1007/s00531-003-0363-6

Simpson, C. (1986). Fabric development in brittle-to-ductile shear zones. Pure and Applied Geophysics, 124(1-2), 269288. https://doi.org/10.1007/BF00875728

Sippel, J., Scheck-Wenderoth, M., Reicherter, K., \& Stanislaw Mazur, S. (2009). Paleostress states at the south-western margin of the Central European Basin System-application of fault-slip analysis to unravel a polyphase deformation pattern. Tectonophysics, 470(1-2), 129-146. https://doi. org/10.1016/j.tecto.2008.04.010 
Smeraglia, L., Berra, F., Billi, A., Boschi, C., Carminati, E., \& Doglioni, C. (2016). Origin and role of fluids involved in the seismic cycle of extensional faults in carbonate rocks. Earth and Planetary Science Letters, 450, 292-305. https:// doi.org/10.1016/j.epsl.2016.06.042

Smith, L., Porster, C. B., \& Evans, J. P. (1990). Interaction of faults zones, fluid flow, and heat transfer at the basin scale. En: Hydrogeology of permeability environments. (pp. 41-67). Vol. 2. International Association of Hydrogeologists.

Smith, M. J., \& Pain, C. F. (2009). Applications of remote sensing in geomorphology. Progress in Physical Geography: Earth and Environment, 33(4), 568-582. https://doi. org/10.1177/0309133309346648

Snoke, A. W., Tullis, J., \& Todd, V. R. (1998). Fault related rocks: A photographic atlas. Princeton University Press.

Spear, F. S. (1993). Metamorphic phase equilibria and pressure-temperature-time paths. Monograph Series, Mineralogical Society of America, D.C.

Sperner, B., \& Ratschbacher, L. (1994). A Turbo Pascal program package for graphical presentation and stress analysis of calcite deformation. Zeitschrift der Deutschen Geologischen Gesellschaft, 145, 414-423.

Sperner, B., Ratschbacher, L., \& Ott, R. (1993). Fault-striae analysis: a Turbo Pascal program package for graphical presentation and reduced stress tensor calculation. Computers \& Geosciences, 19(9), 1361-1388. https://doi. org/10.1016/0098-3004(93)90035-4

Sperner, B., \& Zweigel, P. (2010). A plea for more caution in fault-slip analysis. Tectonophysics, 482(1-4), 29-41. https:// doi.org/10.1016/j.tecto.2009.07.019

Spray, J. G. (1995). Pseudotachylyte controversy: Fact or friction? Geology, 23(12), 1119-1122. https://doi.org/ 10.1130/0091-7613(1995)023<1119:PCFOF>2.3.CO;2

Spruzeniece, L., \& Piazolo, S. (2015). Strain localization in brittle-ductile shear zones: Fluid-abundant vs. fluid-limited conditions (an example from Wyangala area, Australia). Solid Earth Discussions, 7(2), 1399-1446. https://doi. org/10.5194/sed-7-1399-2015

Srivastava, D. C., Lisle, R. J., \& Vandycke, S. (1995). Shear zones as a new type of paleostress indicator. Journal of Structural Geology, 17(5), 663-673. https://doi.org/10.1016/01918141(94)00084-D

Steenken, A., Siegesmund, S., \& Heinrichs, T. (2000). The emplacement of the Rieserferner Pluton (Eastern Alps, Tyrol): Constraints from field observations, magnetic fabrics and microstructures. Journal Structural Geology, 22(11-12), 1855-1873. https://doi.org/10.1016/S0191-8141(00)00071-7

Steffen, K. J., \& Selverstone, J. (2006). Retrieval of P-T information from shear zones: Thermobarometric consequences of changes in plagioclase deformation mechanisms. Contributions to Mineralogy and Petrology, 151, 600. https://doi. org/10.1007/s00410-006-0073-8

Stewart, J. R., \& Betts, P. G. (2010). Late Paleo-Mesoproterozoic plate margin deformation in the southern Gawler Craton: Insights from structural and aeromagnetic analysis. Precambrian Research, 177(1-2), 55-72. https://doi. org/10.1016/j.precamres.2009.11.004

Stewart, J. R., Betts, P. G., Collins, A. S., \& Schaefer, B. F. (2009). Multi-scale analysis of Proterozoic shear zones: An integrated structural and geophysical study. Journal of Structural Geology, 31(10), 1238-1254. https://doi.org/10.1016/j. jsg.2009.07.002

Stipp, M., Stünitz, H., Heilbronner, R., \& Schmid, S. M. (2002). Dynamic recrystallization of quartz: Correlation between natural and experimental conditions. In S. De Meer, M. R. Drury, J. H. P. De Bresser, \& G. M. Pennock (eds.), Deformation mechanisms, rheology and tectonics: Current status and future perspectives (pp. 171-190). Special Publication vol. 200. Geological Society of London.

Stockli, D. F., Surpless, B. E., Dumitru, T. A., \& Farley, K. A. (2002). Thermocrhonological constraints on the timing and magnitude of Miocene and Pliocene extension in the central Wassuk Range, western Nevada. Tectonics, 21(4), 10-28. https://doi.org/10.1029/2001TC001295

Storti, F., Holdsworth, R. E., \& Salvini, F. (2003). Intraplate strike-slip deformation belts. In F. Storti, R. E. Holdsworth, \& F. Salvini (eds.), Intraplate strike-slip deformation belts (pp. 1-14). Special Publication vol. 210. Geologicas Society of London

Stünitz, H. (1998). Syndeformational recrystallization: Dynamic or compositionally induced? Contribution to Mineralogy and Petrology, 131, 219-236. https://doi.org/10.1007/ s004100050390

Süssenberger, A., Schmidt, S. T., Wemmer, K., Baumgartner, L. P., \& Grobéty, B. (2017). Timing and thermal evolution of fold-and-thrust belt formation in the Última Esperanza District, $51^{\circ} \mathrm{S}$ Chile: Constraints from K-Ar dating and illite characterization. GSA Bulletin, 130(5), 975- 998. https:// doi.org/10.1130/B31766.1 
Swanson, M. T. (1992). Fault structure, wear mechanis$\mathrm{ms}$ and rupture processes in pseudotachylyte generation. Tectonophysics, 204(3-4), 223-242. https://doi.org/10.1016/0040-1951(92)90309-T

Tagami, T. (2012). Thermochronological investigation of fault zones. Tectonophysics, 538-540, 67-85. https://doi. org/10.1016/j.tecto.2012.01.032

Tagami, T. (2019). Application of fission-track thermochronology to understand fault zones (pp. 221-233). In M. Malusà, \& P. Fitzgerald (eds.). Fission-track thermochronology and its application to geology. Springer. https://doi. org/10.1007/978-3-319-89421-8_12

Tagami, T., \& Murakami, T. (2007). Probing fault zone heterogeneity on the Nojima fault: Constraints from zircon fission-track analysis of borefole samples. Tectonophysics, 443(34), 139-152. https://doi.org/10.1016/j.tecto.2007.01.013

Ten Grotenhuis, S. M., Trouw, R. A. J., \& Passchier, C. W. (2003). Evolution of mica fish in mylonitic rocks. Tectonophysics, 372(1-2), 1-21. https://doi.org/10.1016/S00401951(03)00231-2

Thakur, P., Srivastava, D. C., \& Gupta, P. K. (2020). HGA: A genetic algorithm method for direct estimation of paleostress states from heterogeneous fault-slip data. Journal of Structural Geology, 138, 104084. https://doi.org/10.1016/j. jsg.2020.104084

Thigpen, J. R., Law, R. D., Lloyd, G. E., \& Brown, S. J. (2010). Deformation temperatures, vorticity of flow, and strain in the Moine thrust zone and Moine nappe: Reassessing the tectonic evolution of the Scandian foreland-hinterland transition zone. Journal of Structural Geology, 32(7), 920940. https://doi.org/10.1016/j.jsg.2010.05.001

Tillberg, M., Drake, H., Zack, T., Hogmalm, J., \& Astrom, M. (2017). In situ Rb-Sr dating of fine-grained vein mineralizations using LA-ICP-MS. Procedia Earth and Planetary Science, 17, 464-467. https://doi.org/10.1016/j. proeps.2016.12.117

Tillberg, M., Drake, H., Zack, T., Kooijman, E., Whitehouse, M. J., \& Åström, M. E. (2020). In situ Rb-Sr dating of slickenfibres in deep crystalline basement faults. Scientific Reports, 10, 1-13, 2020. https://doi.org/10.1038/s41598-01957262-5

Timms, N. E., Kinny, P. D., Reddy, S. M., Evans, K., Clark, C., \& Healy, D. (2011). Relationship among titanium, rare Earth elements, $\mathrm{U}-\mathrm{Pb}$ ages and deformation microstructures in zircon: Implications for Ti-in-zircon thermometry. Chem- ical Geology, 280(1-2), 33-46. https://doi.org/10.1016/j. chemgeo.2010.10.005

Tinkham, D. K. (2007). Metamorphic phase equilibria modeling: Techniques and programs. An informal short course manual. The University of Alabama. Metamorphic Studies Group. October 22-24.

Torgersen, E., \& Viola, G. (2014). Structural and temporal evolution of a reactivated brittle-ductile fault. Part I: Fault architecture, strain localization mechanisms and deformation history. Earth and Planetary Science Letters, 407, 205220. https://doi.org/10.1016/j.epsl.2014.09.019

Tranos, M. D. (2009). Faulting of Lemnos Island: A mirror of faulting of the North Aegean Trough (Northern Greece). Tectonophysics, 467(1-4), 72-88. https://doi.org/10.1016/j. tecto.2008.12.018

Tranos, M. D. (2011). Strymon and Strymonikos Gulf basins (Northern Greece): Implications on their formation and evolution from faulting. Journal of Geodynamics, 51(4), 285-305. https://doi.org/10.1016/j.jog.2010.10.002

Trouw, R. A. J., Passhier, C. W., \& Wiersma, D. R. (2010). Atlas of mylonites, and related microstructures (2nd ed.). Springer Science and Business Media. https://doi.org/10.1007/9783-642-03608-8

Truesdell, C. (1953). Two measures of vorticity. Journal of Rational Mechanics Analysis, 2, 173-217. https://www.jstor. org/stable/24900328

Turcotte, D. L. (1989). Fractals in geology and geophysics. Pure and Applied Geophysics, 131(1-2), 171-196. https://doi. org/10.1007/bf00874486

Turcotte, D. L. (1997). Fractals and chaos in geology and geophysics (2nd ed.). Cambridge University Press. https://doi. org/10.1017/CBO9781139174695

Turner, F. J., \& Weiss, L. E. (1963). Structural analysis of metamorphic tectonites. McGraw-Hill Book Company, Inc.

Twiss, R. J., \& Unruh, J. R. (1998). Analysis of fault slip inversions: Do they constrain stress or strain rate? Journal of Geophysical Research: Solid Earth, 103(B6), 12205-12222. https://doi.org/10.1029/98JB00612

Uysal, T. I., Feng, Y., Zhao, J.-X., Altunel, E., Weatherley, D., Karabacak, V., Cengiz, O., Golding, S. D., Lawrence, M. G., \& Collerson, K. D. (2007). U-series dating and geochemical tracing of late Quaternary travertine in co-seismic fissures. Earth and Planetary Science Letters, 257(3-4), 450-462. https://doi.org/10.1016/j.epsl.2007.03.004 
Van Daele, J., Dewaele, S., Melcher, F., Onuk, P., Spikings, R., Glorie, S., Jepson, G., \& Muchez, P. (2020). Geochronology of metamorphism, deformation and fluid circulation: A comparison between and Ar-Ar phyllosilicate and U-Pb apatite systematics in the Karagwe-Ankole Belt (Central Africa). Gondwana Research, 83, 279-297. https://doi.org/10.1016/j. gr.2020.02.008

Van der Pluijm, B. A., Hall, C. M., Vrolijk, Pevear, D. R., \& Covey, M. C. (2001). The Dating of shallow faults in the Earth's crust. Nature, 412(6843), 172-5. https://doi. org/10.1038/35084053

Van der Pluijm, B. A., Vrolijk, P. J., Pevear, D. R., Hall, C. M., \& Solum, J. (2006). Fault dating in the Canadian Rocky Mountains: Evidence for late Cretaceous and early Eocene orogenic pulses. Geology, 34(10), 837-840. https://doi. org/10.1130/G22610.1

Van der Pluijm, V. A., Mezger, K., Cosca, M. A., \& Essene, E. J. (1994). Determining the significance of high-grade shear zones by using temperature-time paths, with examples from the Grenville orogen. Geology, 22(8), 743-746. https://doi.org/10.1130/0091-7613(1994)022<0743:DT$\mathrm{SOHG}>2.3 . \mathrm{CO} ; 2$

Vannucchi, P., Maltman, A., Bettelli, G., \& Clennell, B. (2003). On the nature of scaly fabric and scaly clay. Journal of Structural Geology, 25(5), 673-688. https://doi.org/10.1016/ S0191-8141(02)00066-4

Vauchez, A., Tommasi, A., \& Mainprice, D. (2012). Fault (shear zones) in the Earth's mantle. Tectonophysics, 558-559, 1-27. https://doi.org/10.1016/j.tecto.2012.06.006

Vega Granillo, R., Calmus, T., Meza Figueroa, D., Ruiz, J., Talavera Mendoza, O., \& López Martínez, M. (2009). Structural and tectonic evolution of the Acatlán Complex, Southern Mexico: Its role in the collisional history of Laurentia and Gondwana. Tectonics, 28(4), TC4008. https:// doi.org/10.1029/2007TC002159

Velandia, F. A. P. (2017). Cinemática de las fallas mayores del macizo de Santander: Énfasis en el modelo estructural y temporalidad al sur de la falla de Bucaramanga (Ph.D. thesis), Universidad Nacional de Colombia, Bogotá.

Verhaert, G., Muchez, P., Sintubin, M., Similox Tohon, D., Vandycke, S., \& Waelkens, M. (2003). Reconstruction of neotectonic activity using carbonate precipitates: A case study from northwestern extremity of the Isparta Angle (SW Turkey). Journal of Geochemical Exploration, 78-79, 197201. https://doi.org/10.1016/S0375-6742(03)00070-0
Vernon, R. H., \& Clarke, G. L. (2008). Principles of metamorphic petrology. Cambridge University Press.

Vernon, R. H, Holdswoth, R. E., Selby, D., Dempsey, E., Finlay, A. J., \& Fallick, A. E. (2014). Structural characteristics and Re-Os dating of quartz-pyrite veins in the Lewisian Gneiss Complex, NW Scotland: Evidence of an Early Paleoproterozoic hydrothermal regime during terrane amalgamation. Precambrian Research, 246, 256-267. https://doi. org/10.1016/j.precamres.2014.03.007

Ganerød, G. V., Braathen, A., \& Willemoes Wissing, B. (2008). Predictive permeability model of extensional faults in crystalline and metamorphic rocks; verification by pre-grouting in sub-sea tunnels in Norway. Journal of Structural Geology, 30(8), 993-1004. https://doi.org/10.1016/j.jsg.2008.04.001

Villa, I. (2002). Isotopic closure. Terra Nova, 10(1), 42-47. https://doi.org/10.1046/j.1365-3121.1998.00156.x

Villa, I. M., Bucher, S., Bousquet, R., Kleinhanns, I. C., \& Schmid, S. M. (2014). Dating polygenetic metamorphic assemblages along a transect across the Western Alps. Journal of Petrology, 55(4), 803-830. https://doi.org/10.1093/petrology/egu007

Vinasco, C., \& Cordani, U. (2012). Reactivation episodes of the Romeral Fault System in the northwestern part of Central Andes, Colombia, through ${ }^{39} \mathrm{Ar}-{ }^{40} \mathrm{Ar}$ and $\mathrm{K}-\mathrm{Ar}$ results. Boletín Ciencias de la Tierra, 32, 111-124.

Vinasco, C. J. (2001). A utilização da metodologia 40Ar-39Arpara o estudo de reativações tectônicas em zonas de cisalhamentos. Paradigma, O Falhamento de Romeral nos Andes Centrais de Colômbia (Master thesis). Universidade de São Paulo.

Viola, G., Scheiber, T., Fredin, O., Zwingmann, H., Margreth, A., \& Knies, J. (2016). Deconvoluting complex structural histories archived in brittle fault zones. Nature Communications, 7, 13448. https://doi.org/10.1038/ncomms 13448

Vissers, R. L. M., Van Hinsbergen, D. J. J., Wilkinson, C. M., \& Ganerød, M. (2016). Middle Jurassic shear zones at Cap de Creus (eastern Pyrenees, Spain): A record of predrift extension of the Piemonte-Ligurian Ocean? Journal of the Geological Society, 174(2), 289-300. https://doi. org/10.1144/jgs2016-014

Vitale, S., \& Mazzoli, S. (2008). Heterogeneous shear zone evolution: The role of shear strain hardening/softening. Journal Structural Geology, 30(11), 1383-1395. https://doi.org/ 10.1016/j.jsg.2008.07.006 
Vrolijk, P., Pevear, D., Covey, M., \& La Riviere, A. (2018). Fault gouge dating: History and evolution. Clay Minerals, 53(3), 305-324. https://doi.org/10.1180/clm.2018.22

Vrolijk, P., \& van der Plujim, B. A. (1999). Clay gouge. Journal of Structural Geology, 21(8-9), 1039-1048. https://doi. org/10.1016/S0191-8141(99)00103-0

Wallace, R. (1951). Geometry of shearing stress and relation to faulting. The Journal of Geology, 59(2), 118-130. https://doi. org/10.1086/625831

Wallis, S. R. (1992). Vorticity analysis in a metachert from the Sanbagawa belt, SW Japan. Journal of Structural Geology, 14(3), 271-280. https://doi.org/10.1016/01918141(92)90085-B

Wang, B., Cluzel, D., Shu, L., Faure, M., Charvet, J., Chen, Y., Meffre, S., \& Jong, K. (2009). Evolution of calc-alkaline to alkaline magmatism through Carboniferous convergence to Permian transcurrent tectonics, western Chinese Tianshan. International Journal of Earth Sciences, 98(6), 1275. https://doi.org/10.1007/s00531-008-0408-y

Wang, Y., Zwingmann, H., Zhou, L., Lo, C., Viola, G., \& Hao, J. (2016). Direct dating of folding events by ${ }^{40} \mathrm{Ar} /{ }^{39} \mathrm{Ar}$ analysis of synkinematic muscovite from flexural-slip planes. Journal Structural Geology, 83, 46-59. https://doi.org/10.1016/j. jsg.2015.12.003

Watanabe, Y., Nakai, S. I., \& Lin, A. (2008). Attempt to determine $\mathrm{U}$-Th ages of calcite veins in the Nojima fault zone, Japan. Geochemical Journal, 42(6), 507-513. https://doi. org/0.2343/geochemj.42.507

Webb, L. E., Johnson, C. L., \& Minjin, C. (2010). Late Triassic sinistral shear in the East Gobi Fault Zone, Mongolia. Tectonophysics, 495(3-4), 246-255. https://doi.org/10.1016/j. tecto.2010.09.033

Wells, M. L., Snee, L. W., \& Blythe, A. E. (2000). Dating of major normal fault systems using western United States. Journal of Geophysical Research: Solid Earth, 105(B7), 1630316327. https://doi.org/10.1029/2000JB900094

Wenk, H. R., Johnson, L. R., \& Ratschbacher, L. (2000). Pseudotachylytes in the Eastern Peninsular Ridges of California. Tectonophysics, 321(2), 253-277. https://doi.org/10.1016/ S0040-1951(00)00064-0

Wernicke, R. S., \& Lippolt, H. J. (1997). (U+Th)-He evidence of Jurassic continuous hydrothermal activity in the Schwarzwald basement, Germany. Chemical Geology, 138(3-4), 273-285. https://doi.org/10.1016/S0009-2541(97)00020-X
White, S. H., Burrows, S. E., Carreras, J., Shaw, N. D., \& Humphreys, F. J. (1980). On mylonites in ductile shear zones. Journal of Structural Geology, 2(1-2), 175-187. https://doi. org/https://doi.org/10.1016/0191-8141(80)90048-6

Whitmeyer, S. J. (2008). Dating fault fabrics using modern techniques of ${ }^{40} \mathrm{Ar} /{ }^{39} \mathrm{Ar}$ thermochronology: Evidence for Paleozoic deformation in the Eastern Sierras Pampeanas, Argentina. Journal of the Virtual Explorer, 30. https://doi. org/10.3809/jvirtex.2008.00207

Wibberley, C. A. J., Yielding, G., \& Di Toro, G. (2008). Recent advances in the under-standing of fault zone internal structure: A review. In C. A. J. Wibberley, W. Kurz, J. Imber, R. E. Holdsworth, \& C. Collettini (eds.), The internal structure of fault zones: Implications for mechanical and fluid-flow properties (pp. 5-33). Special Publication vol. 299. Geological Society of London. https://doi.org/10.1144/SP299.2

Winter, J. D. (2001). An introduction to igneous and metamorphic petrology. Prentice Hall.

Wise, D. U., Dunn, D. E., Engelder, J. T., Gieser, P. A., Hatcher, R. D., Kish, S. A., Odom, A. L., \& Schamel, S. (1984). Fault-related rocks: Suggestions for terminology. Geology, 12(7), 391394. https://doi.org/10.1130/0091-7613(1984)12<391:FRSFT>2.0.CO;2

Wolff, R., Dunkl, I., Kiesselbach, G., Wemmer, K., \& Siegesmund, S. (2012). Thermochronological constraints on the multiphase exhumation history of the IvreaVerbano Zone of the Southern Alps. Tectonophysics, 579, 104-117. https:// doi.org/10.1016/j.tecto.2012.03.019

Wolfler, A., Kurz, W., Danisik, M., \& Rabitsch, R. (2010). Dating of fault zone activity by apatite fission track and apatite (U-Th)/He thermochronometry: A case study from the Lavanttal fault system (Eastern Alps). Terra Nova, 22(4), 274-282. https://doi.org/10.1111/j.1365-3121.2010.00943.x

Woodcock, N. H., \& Mort, K. (2008). Classification of fault breccias and related fault rocks. Geological Magazine, 145(3), 435-440. https://doi.org/10.1017/S0016756808004883

Wu, F. T. (1978). Mineralogy and physical nature of clay gouge. Pure and Applied Geophysics, 116(4-5), 655-689. https:// doi.org/10.1007/BF00876531

Xypolias, P. (2009). Some new aspects of kinematic vorticity analysis in naturally deformed quartzites. Journal of Structural Geology, 31(1), 3-10. https://doi.org/10.1016/j. jsg.2008.09.009

Xypolias, P. (2010). Vorticity analysis in shear zones: A review of methods and applications. Journal of Structur- 
al Geology, 32(12), 2072-2092. https://doi.org/10.1016/j. jsg.2010.08.009

Xypolias, P., Spanos, D., Chatzaras, V., Kokkalas, S., \& Koukouvelas, I. (2010). Vorticity of flow in ductile thrust zones: Examples from the Attico-Cycladic Massif (Internal Hellenides, Greece). In R. D. Law, R. W. H. Butler, R. E. Holdsworth, M. Krabbendam, \& R. A. Strachan (eds.), Continental tectonics and mountain building: The legacy of Peach and Horne (pp. 687-714). Special Publications vol. 335. Geological Society of London. https://doi.org/10.1144/ SP335.28

Xypolias, P., \& Kokkalas, S. (2006). Heterogeneous ductile deformation along a mid-crustal extruding shear zone: An example from the External Hellenides (Greece) (pp. 497-516). Special Publications vol. 268. Geological Society of London. https://doi.org/10.1144/GSL.SP.2006.268.01.23

Žalohar, J. (2014). T-Tecto Studio X5. Integrated software for structural analysis of earthquake focal-machanism and fault-slip data. Introductory tutorial.
Zaun, P. E., \& Wagner G. A. (1985). Fission-track stability in zircons under geological conditions. Nuclear Tracks and Radiation Measurements, 10(3), 303-307. https://doi. org/10.1016/0735-245X(85)90119-X

Zulauf, G. (2001). Structural style, deformation mechanisms and paleodifferential stress along an exposed crustal section: Constraints on the rheology of quartzofeldspathic rocks at supra- and infrastructural levels (Bohemian Massif). Tectonophysics, 332(1-2), 211-237. https://doi. org/10.1016/S0040-1951(00)00258-4

Zuluaga, C., Stowell, H., \& Tinkham, D. (2006). Thermodynamic modeling: A tool for understanding phase equilibria \& metamorphic processes. A workshop manual.

Zwingmann, H., \& Mancktelow, N. S. (2004). Timing of Alpine fault gouges. Earth and Planetary Science Letters, 223(3-4), 415-425. https://doi.org/10.1016/j.epsl.2004.04.041 